
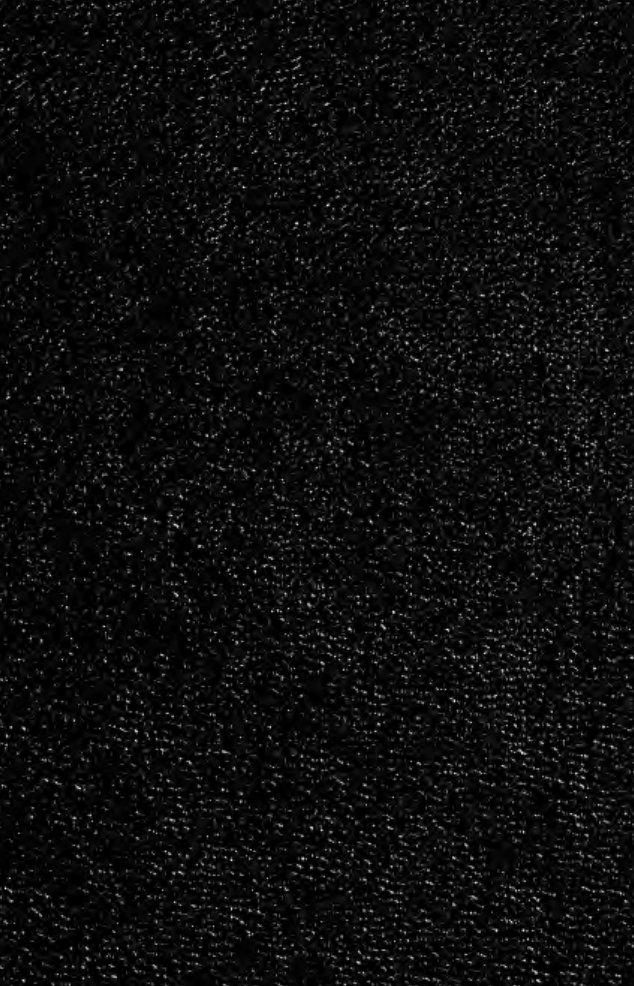

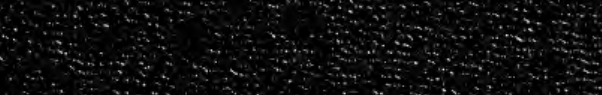




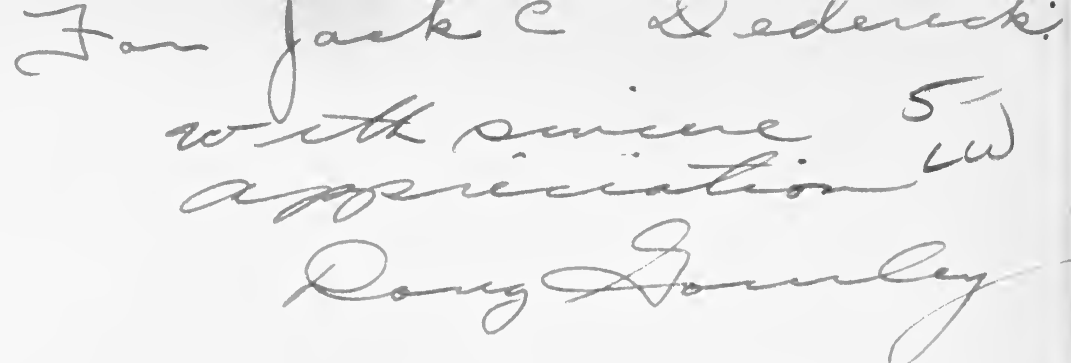

$2:$
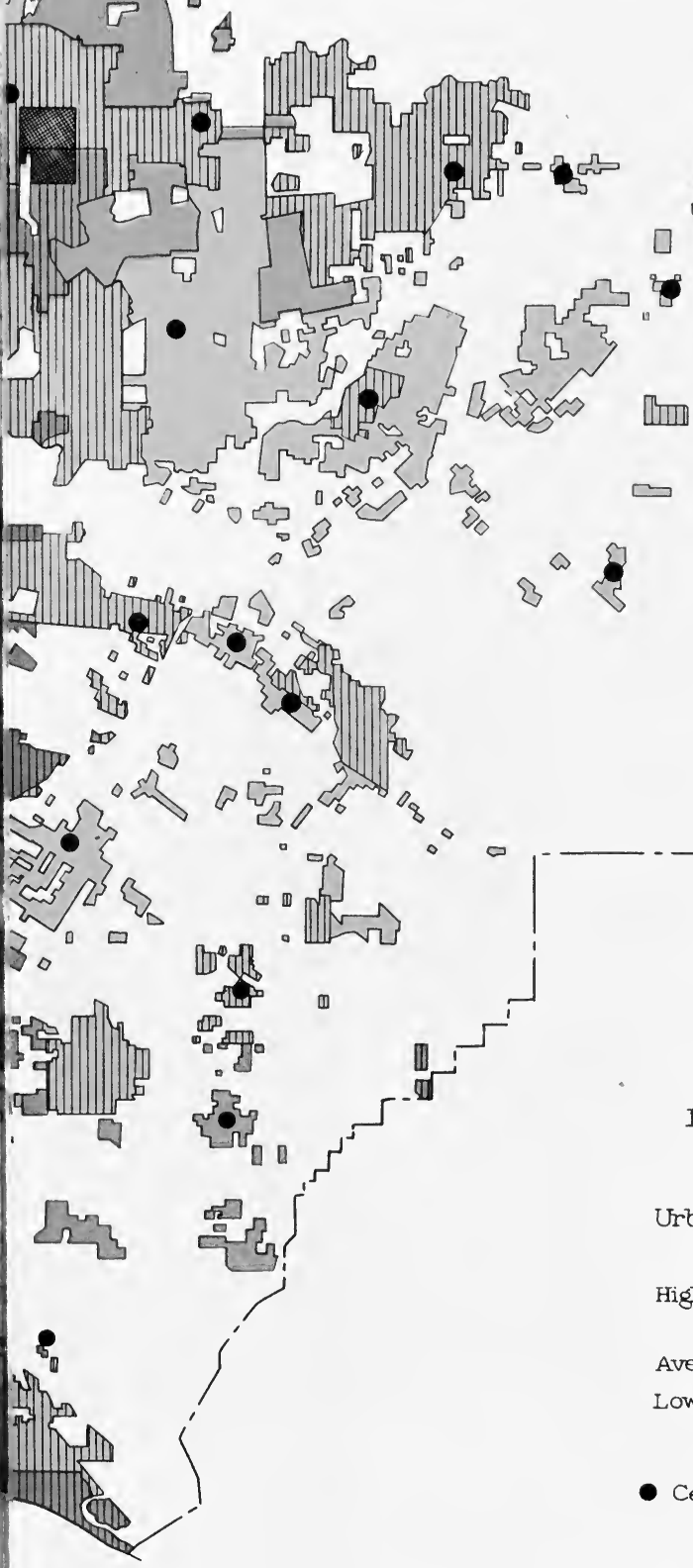

(1)

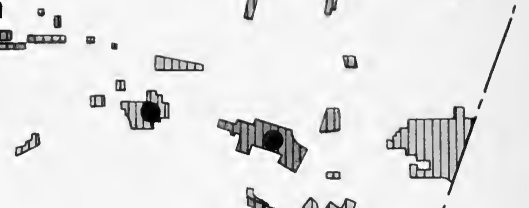

메핌
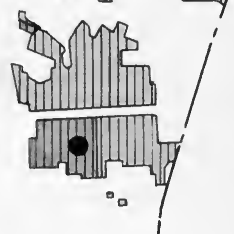

SOCIAL AREAS

Based on Indexes of Social Rank,

Urbanization, and Segregation.

Urbanization

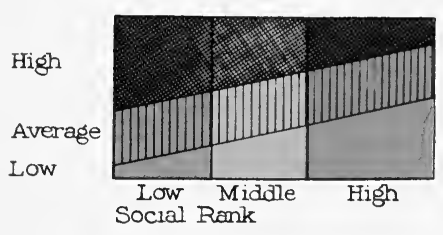

Census tracts with high indexes of segregation 
From the collection of the

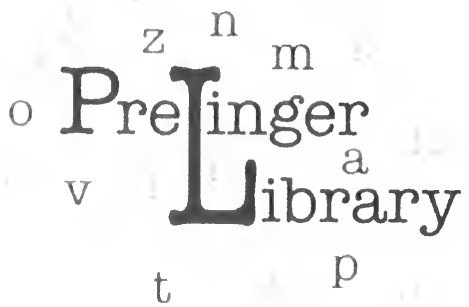

San Francisco, California 2006 


\section{PUBLIC RELATIONS}

AND

THE POLICE 


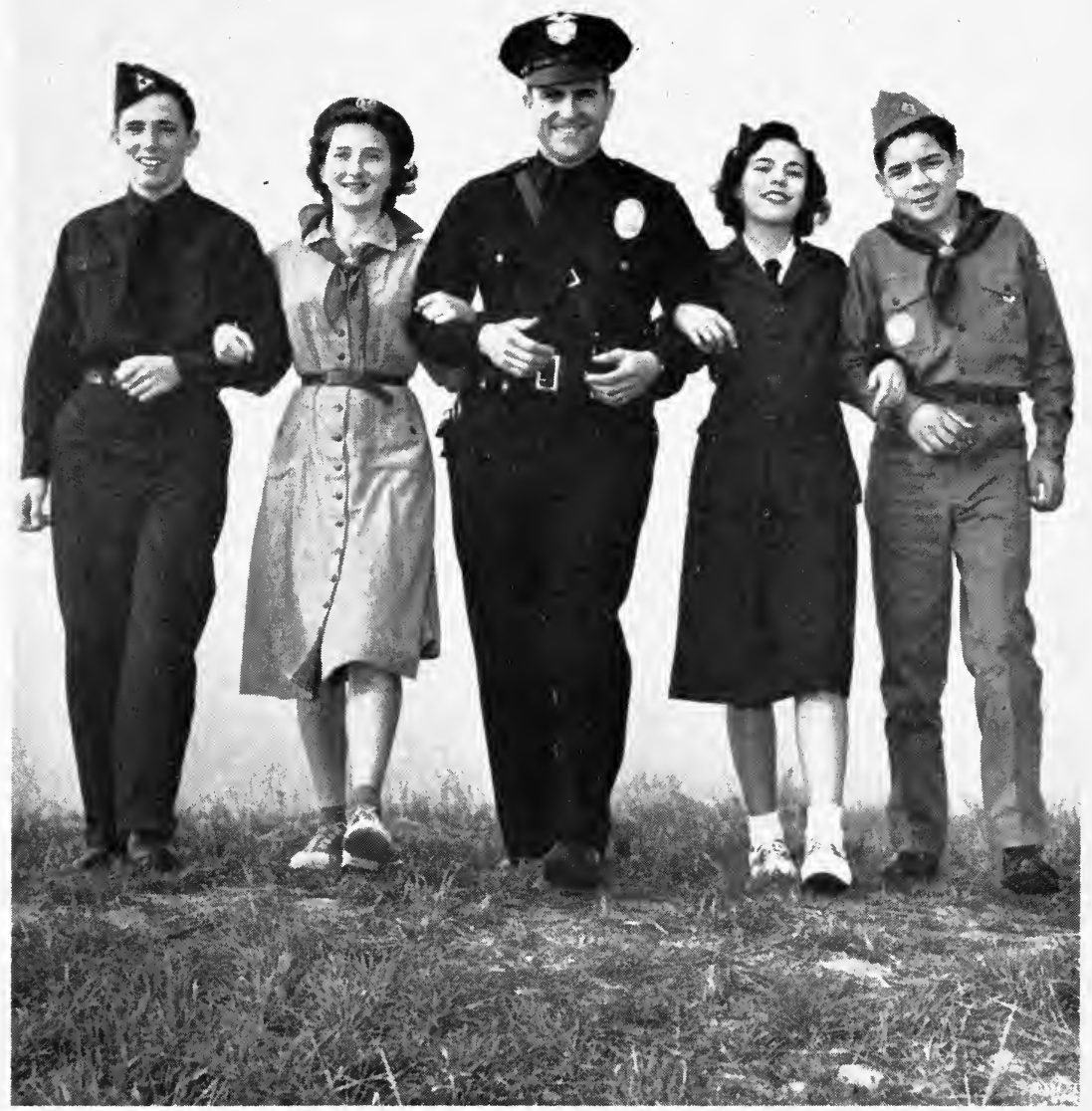

Tomorrow's Citizens and the Police 


\title{
PUBLIG RELATIONS
}

\section{AND \\ THE POLICE}

\author{
By \\ G. DOUGLAS GOURLEY, M.S. \\ Captain, Los Angeles Police Department \\ Commander, Training Division \\ Instructor, Police Science and Administration \\ Civic Center Division \\ School of Public Administration \\ University of Southern California \\ Los Angeles, California
}

With a Foreword by

AUGUST VOLLMER

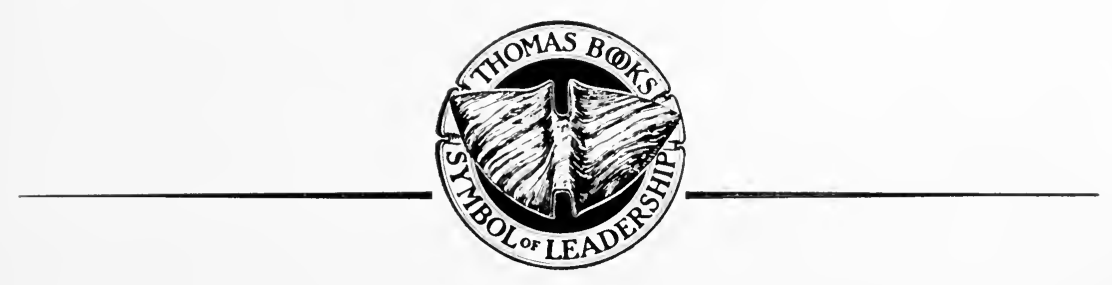

CHARLES C THOMAS - PUBLISHER

Springfield - Illinois - U.S.A. 


\section{CHARLES C THOMAS - PUBLISHER \\ BaNNerstone House}

301-327 East Lawrence Avenue, Springfield, Illinois, U.S.A.

Published simultaneously in the British Commonwealth of Nations by

Blackifell Scientific Publications, Ltd., Oxford, England

Published simultaneously in Canada by

The Ryerson Press, Toronto

This monograph is protected by copyright. No part of it may be reproduced in any manner

without written permission from the publisher.

Copyright 1953, by Charles C Thomas - Publisher 
To

My Wife

Virginia 



\section{FOREWORD}

P

OLICEMEN receive small pay and few commendations for their invaluable contributions to our social order; they travel their beats day and night, regardless of weather conditions; their hours of employment are shifted from month to month, thus hampering comfortable enjoyment of family life; and they are exposed to more hazards to life and health than are persons engaged in most other public services. Less than two hundred thousand peace officers hold an estimated six million criminals in check, and reduce to an appreciable extent unlawful attacks upon law-abiding citizens; they preserve the peace in industrial disputes, race riots and disasters; they regulate the flow of traffic, eliminate the accident-prone driver and keep down the death and injury rate on the streets and highways; they are compelled to enforce unpopular laws; and they play a more important part than is generally known in preventing problem children from becoming habitual offenders.

In spite of their magnificent efforts, a large percentage of the people they serve so faithfully and efficiently often appear ungrateful, hypercritical and, not infrequently, seem to place obstacles in the path of their police officers which prevent them from discharging their obligations in the most satisfactory manner.

In fact, many people refuse to cooperate with the police either as informers, complainants, witnesses or jurors. Newspapers frequently ridicule their best efforts, preachers denounce them and the movies, radio and television occasionally portray them as dishonest incompetents. Therefore, it is pertinent to inquire: Why are policemen held in such low esteem? What have policemen done or left undone which has produced such unfavorable public attitudes? And, finally, what can policemen do to win the support and respect of the citizens they serve?

In this notable contribution to police management, the author focuses the statistical spotlight on relations that presently exist between the public and police, and in so doing illuminates the factors that have produced present public attitudes, torvard the 
police. In a scholarly manner, the author has also outlined the methods by which police chiefs may institute similar inquiries and obtain authentic information concerning the standing of their department in the thoughts and feelings of the people they serve. Finally, very practical suggestions are submitted by the author for the consideration of policemen and police executives which, if followed, will definitely improve police public relations and help win for the police the public esteem and support they must have to adequately and efficiently perform their assigned functions.

Berkeley, California

August Vollmer 


\section{PREFACE}

$\mathrm{T}$

HE IMPORTANCE of public support in the enforcement of law and order cannot be over-emphasized. Policemen represent only a small fraction of the public which they serve, and can never adequately discharge their obligations to protect life and property unless they are reinforced by the "good will" and cooperation of the public.

It is highly important that the citizen and the policeman understand and appreciate each other's problems and viewpoints. The citizen has definite obligations in this matter. He must realize that his security and welfare are, to a large measure, dependent upon the maintenance of an orderly society which, in turn, is dependent upon the efficiency and prestige of the police.

The policeman, on his part, must always remember that law enforcement is not an end in itself; but is, rather, a means to an end-and that end is the maintenance of an orderly society.

During the past 1 oo years the police have made great strides along the road toward professionalization. As in other fields, however, the greatest advances have been those which deal with scientific techniques and equipment. The social problems in policing have not received their fair share of attention.

The present manuscript is an effort to add to the available knowledge in one segment of this sociological aspect of policing; namely, the nature, intensity, and, to some extent, the causes of public attitudes toward the police-commonly called "Police Public Relations."

G. D. G. 



\section{ACKNOWLEDGMENTS}

I wish to express my sincere appreciation to William H. Parker, Chief of Police, and to Major General William A. Worton, United States Marine Corps (Retired), former Chief of Police of Los Angeles, whose broad vision and progressive attitudes have made this searching inquiry possible.

To Dean Emery E. Olson, Drs. John M. Pfiffner and John D. Gerletti, and Mr. John P. Kenney, of the School of Government, University of Southern California, under whose supervision this survey was conducted, I am indebted for valuable advice and encouragement. I also wish to acknowledge the help given me by Donal E. J. McNamara, New York Institute of Criminology.

In an effort to learn what had been done by others to determine attitudes of the public toward their police, and to evaluate the various survey techniques available, reliance was not placed upon literature alone. An extensive correspondence was initiated with many persons in the fields of Police Administration, Education, and Market and Consumer Research.

I desire to acknowledge particular assistance of this nature from: Frank M. Boolsen, Fresno State College; George Gallup, American Institute of Public Opinion; John D. Gerletti, University of Southern California; Richard O. Hankey, College of the Sequoias; Richard L. Holcomb, State University of Iowa; J. D. Holstrom, Chief of Police, Berkeley, California; Franklin M. Kreml, Director, Traffic Division, International Association of Chiefs of Police; David A. Kronick, National Opinion Research Center; V. A. Leonard, State College of Washington; Rollin M. Perkins, University of California at Los Angeles; Clarence E. Ridley, International City Managers' Association; Elmo Roper, International Public Research, Inc.; Willard E. Schmidt, San Jose State College; Robert H. Scott, Michigan State College; Gordon H. Sheehe, University of Washington; Bruce Smith, Institute of Public Administration; August Vollmer, University of California (Retired); Sidney J. Williams, National Safety Council; and O. W. Wilson, University of California. 
The extensive nature of this inquiry could not have been possible without the enthusiastic cooperation of Captain Stanley Sheldon, Commander of the Public Information Division, and the time-consuming efforts of Sergeants Lenwood D. Rottier and Robert F. Green, Policewoman Sergeant Mary E. Galton, and Officers Denis P. Lynch and Donald G. Ingalls, who acted as enumerators in supervising the filling in of the questionnaires.

Original tabulations from the questionnaires filled 100 pages. Credit for this exhaustive statistical treatment must go to Rhoda Cross, Police Statistician, and to her assistant, Bertha Bindrup, and to the following persons who each played an essential part in the handling of the statistical information: Agnes Vollack, Rose Wackeen, Veleta Reese, Elia Wilson, Helen Dixon, Vivian Gilbert, Hope Hofland, Marguerite Wold, Ruth Barr, Hilda Lancaster, and Irene Luckie.

Sergeant John H. Cummings, of the Planning and Research Division, prepared the charts. The photographs were furnished by courtesy of the Public Information Division, the Traffic Services Division, and the Photographic Section of the Scientific Investigation Division, Los Angeles Police Department. Sergeant Jack C. Dederick is the artist who so generously permitted the inclusion of his cartoons. Mrs. Verdabelle Hooper, Miss Maxine Gindele, and Miss Patricia Newton contributed valuable clerical assistance.

I wish to express my sincere gratitude to Miss Afton Farnsworth, who typed and edited the entire manuscript.

G. D. G. 


\section{CONTENTS}

FOREWORD $\ldots \ldots \ldots \ldots \ldots \ldots \ldots \ldots \ldots \ldots \ldots \ldots \ldots \ldots \ldots$ vii

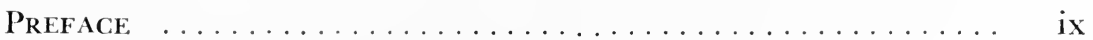

AcknowledgMents $\ldots \ldots \ldots \ldots \ldots \ldots \ldots \ldots \ldots \ldots \ldots \ldots \ldots$

List of ILLUSTRATIONS $\ldots \ldots \ldots \ldots \ldots \ldots \ldots \ldots \ldots \ldots \ldots \ldots \ldots \ldots$

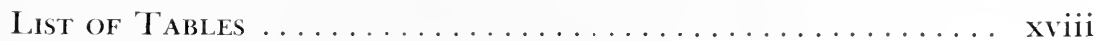

Chapter Page

I. The Public Relations Probleni of the Police ..... 3

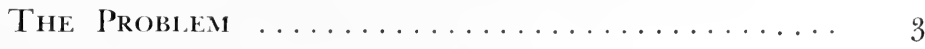

Importance of the Problen $\ldots \ldots \ldots \ldots \ldots \ldots \ldots \ldots$

Adverse beliefs concerning police ........... 3

Non-criminal police contacts ............ 4

Importance of daily contacts ........... 6

Results of poor public relations ........... 6

Importance of This Study .............. 8

Need for sound factual data $\ldots \ldots \ldots \ldots \ldots \ldots$

Organization of material ............. 9

II. Previous Attitude Surveys $\ldots \ldots \ldots \ldots \ldots \ldots \ldots \ldots \ldots$

Origins of Public Opinion Polls ............ 10

Criticisms of Polls and Pollsters ........... 10

Parratt's Contribution $\ldots \ldots \ldots \ldots \ldots \ldots \ldots \ldots \ldots . \ldots \ldots$

Police and Anti-I ynch Legislation ........... 14

Attitudes toward Traffic $\ldots \ldots \ldots \ldots \ldots \ldots \ldots \ldots$

Attitudes toward Civil Service ............ 16

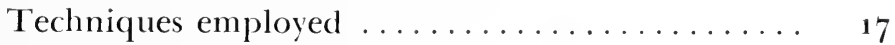

General conclusions ................. 18

Attitudes Toward Traffic Safety ........... ${ }_{18} 8$

Techniques employed .............. 18

Survey findings $\ldots \ldots \ldots \ldots \ldots \ldots \ldots \ldots \ldots$

Attitudes of Germans toward Their Post-War

Police ....................... ${ }_{26}$

Techniques employed $\ldots \ldots \ldots \ldots \ldots \ldots \ldots \ldots \ldots$

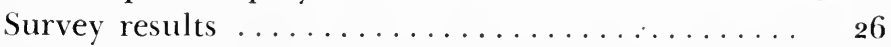

The American Soldier in W'orld War II ....... 28 
III. Research Methods and Sources of Data ........ 29

Survey Techniques $\ldots \ldots \ldots \ldots \ldots \ldots \ldots \ldots \ldots \ldots \ldots \ldots .29$

The open-question or free-answer response $\ldots . .29$

Advantages of techniques selected ......... $3^{0}$

Background information $\ldots \ldots \ldots \ldots \ldots \ldots \ldots \ldots$

Method of Stratification ........................ $3^{1}$

Composition of Los Angeles population ....... $3^{1}$

"Social areas" .................. $3^{1}$

Conversion of postal zones to "social areas" .... 32

Composition of Los Angeles by social area, sex, age,

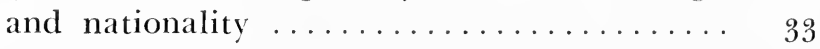

Stratified sample or "universe" ........... 33

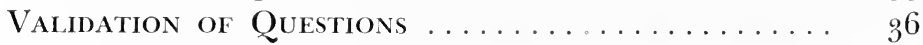

Parratt's contribution $\ldots \ldots \ldots \ldots \ldots \ldots \ldots \ldots 3^{6}$

Auditing the scale $\ldots \ldots \ldots \ldots \ldots \ldots \ldots \ldots \ldots$

The Survey Form ................. 40

Cooperation of respondents ............ $4^{\circ}$

Biographical data ................ $4^{1}$

Multiple-choice questions ............. $4^{1}$

Free-answer responses ............... $4^{1}$

Contacting Respondents ................ 42

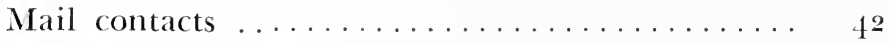

Group contacts ................. 42

Cooperation of the Los Angeles Police Department 42

Tallying Respondents' Replies ............ 43

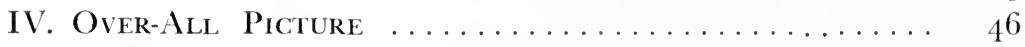

Multiple-Choice Responses ............. $4^{6}$

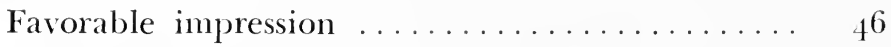

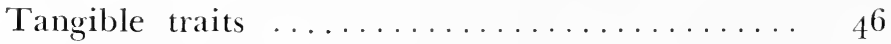

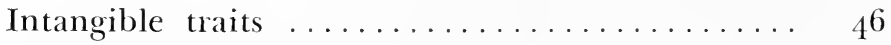

Citizens' lack of knowledge ............ $5^{\text {o }}$

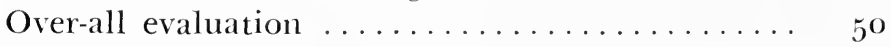

Free-Answer Responses .............. $5^{\mathrm{o}}$

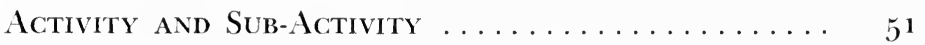

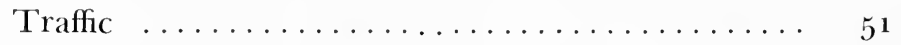

Uniformed motor patrol .............. 53

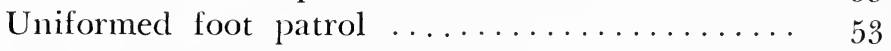

Detective operations ............... 53

Juvenile activities ................. 53

Miscellaneous functions $\ldots \ldots \ldots \ldots \ldots \ldots \ldots, 57$ 
Police department as a whole $\ldots \ldots \ldots \ldots \ldots \ldots 5^{8}$

Police contacts and public relations ........... $5^{8}$

Comment and Sub-Comment $\ldots \ldots \ldots \ldots \ldots \ldots \ldots \ldots$

Attitudes of officers .................. 59

Actions of officers $\ldots \ldots \ldots \ldots \ldots \ldots \ldots \ldots \ldots \ldots$

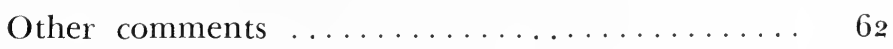

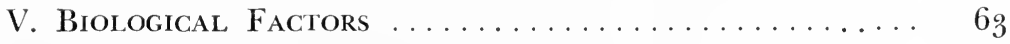

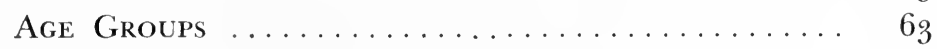

Basis for selection ......................... 63

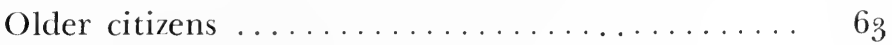

Severest critics .................... 66

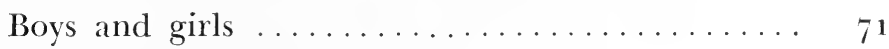

Strength of convictions ............... $7^{1}$

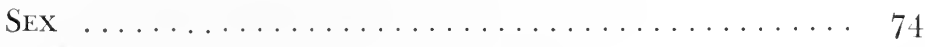

More favorable attitude of males ............ it

Lack of knowledge by females ............. 74

Appearance and physical condition ........... 74

VI. Sociological Factors .................... 75

NATIONALity ......................... 75

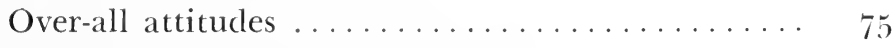

Attitudes regarding specific traits $\ldots \ldots \ldots \ldots \ldots .75$

Exceptions to over-all attitudes ..............

Strength of convictions .................. 77

Marital Status .................... 78

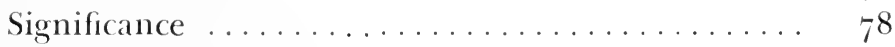

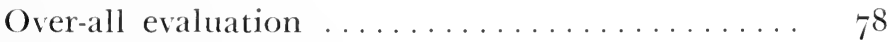

Strength of convictions ............... 78

Education ............................ 79

Composition of the sample .............. $\quad 79$

General trend ...................... 79

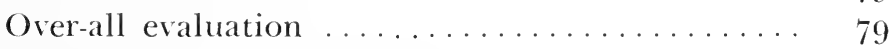

Evaluation of specific traits $\ldots \ldots \ldots \ldots \ldots \ldots 8_{1}$

LENGTH OF Residence . . . . . . . . . . . . . . 82

VII. Occupation $\ldots \ldots \ldots \ldots \ldots \ldots \ldots \ldots \ldots \ldots \ldots \ldots .8_{5}$

Distribution of SAMPLE $\ldots \ldots \ldots \ldots \ldots \ldots \ldots \ldots, 85$

Public Servants $\ldots \ldots \ldots \ldots \ldots \ldots \ldots \ldots \ldots \ldots \ldots \ldots \ldots$

UNSKILLED LABORERS $\ldots \ldots \ldots \ldots \ldots \ldots \ldots \ldots \ldots$

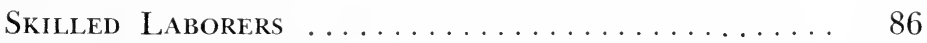

Transportation WORKERS $\ldots \ldots \ldots \ldots \ldots \ldots \ldots, 87$

Professionals $\ldots \ldots \ldots \ldots \ldots \ldots \ldots \ldots \ldots \ldots$ 
Figure 29. A Los Angeles policewoman .............. 73

Figure $3^{0}$. Over-all evaluation by nationality $\ldots \ldots \ldots \ldots \ldots 7^{6}$

Figure 31 . Community activity .................. 80

Figure 32 . Over-all evaluation by length of residence ...... 83

Figure 33 . Evaluation of honesty $\ldots \ldots \ldots \ldots \ldots \ldots \ldots \ldots . \quad 89$

Figure 34 . A favorable contact with housewives .......... 91

Figure 35. The great majority of police work is done under difficult circumstances $\ldots \ldots \ldots \ldots \ldots \ldots \ldots \ldots \ldots \ldots . \ldots \ldots$

Figure 36 . Public relations in the court room ............ 94

Figure 37 . Training for a modern policeman $\ldots \ldots \ldots \ldots \ldots .9^{6}$

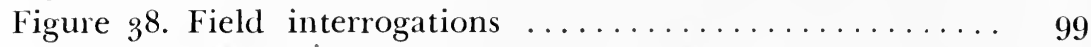

Figure 39. "March of Dimes" Parade, Wilshire Blvd., Los

Angeles .............................. 100

Figure 40 . A thousand eyes are on you .............. 101

Figure 4 1. Conveying the facts $\ldots \ldots \ldots \ldots \ldots \ldots \ldots \ldots \ldots \ldots$

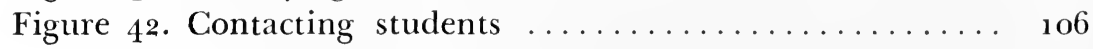

\section{LIST OF TABLES}

I. Stratification of the sample, showing relation to total population before and after weighting in traffic survey ..... 20

II. Attitude of respondents toward traffic law enforcement .... 21

III. Population composition of Los Angeles by social area, sex, age, and nationality .................... 33

IV. Stratification of the actual sample showing relation to total population of Los Angeles ..................... 34

V. Stratification of the adjusted sample showing relation to total population of Los Angeles 


\section{PUBLIC RELATIONS AND \\ THE POLICE}





\section{Chapter I \\ THE PUBLIC RELATIONS PROBLEM OF THE POLICE}

\section{THE PROBLEM}

A

merican Police Departments have a serious public relations problem to face; and upon its correct solution, their eventual success or failure will depend. Despite this situation, very few departments have done much about the problem-and even these few have proceeded with very little factual information about attitudes of people upon which to build an adequate public relations program. ${ }^{1}$

\section{IMPORTANCE OF THE PROBLEM}

Adverse Beliefs Concerning Police: No matter how well a police department is organized, or how efficient and honest its administration, it is judged by individual citizens and, consequently, by the nature of its public contacts. People believe the old adage that "By their fruits, ye shall know them." 2 Police contacts are usually made under difficult circumstances, for there are many adverse beliefs concerning police which exist in varying strength throughout the land. Among these are the frequently found convictions that policemen are uneducated and of low mentality; that they are selected for physical strength and courage alone; that they are of doubtful honesty and integrity; that they are engaged in a continuous offensive against society; that they are often rude and domineering; that they get angry easily, and assume a "smartalec" attitude more easily; that they resort to the illegal "third degree"; and that the only way to be safe from this tyranny is to have wealth or "pull."

Not all of these indictments can be fairly charged to any one

${ }^{1}$ Allen, Eric W.: The Public Relations Problem of the Police. The Commonwealth Review, 2r:212, November, 1939 .

${ }^{2}$ Courtesy. F.B.I. Law Enforcement Bulletin, $8: 33$, November 1, 1939. 
police department; but, unfortunately, at various times and places each has been successfully proved. Today's policemen have inherited the reputation of their predecessors-and the police "past" has been rather inglorious. The iniquity of the fathers is visited upon the children unto the third and fourth generations. Also, despite the fact that many police organizations have made rapid strides and are on the verge of professionalization, current standards in others leave much to be desired.

Non-Griminal Police Contacts: In the early days of police departments, the "good" citizens of the community felt a sincere alliance with the police against thieves and outlaws who preyed upon them. Today, in an urban community, the citizens too often have no such feeling of alliance. Police work is no longer concerned primarily with a small outlaw-group. Modern police departments have become large, complex organizations whose many new duties require intimate day-to-day contacts with all citizens. The greatest number of police contacts today is not with the criminal element of society, but rather with the "good" citizens of a community. It has been estimated that at least go per cent of all police business is not of a strictly criminal nature. ${ }^{3}$

Extensive use of the automobile has made necessary an increasing number of restrictions upon the driving public, and the old division of the community into law-breakers and law-observers has thus been destroyed. Today, everyone is a law-breaker-and many are deliberate offenders. Fines and other penalties for traffic-law violations often leave the violator far from convinced of the justice of such action.

As long as policemen confined their activities to repression, detection, and investigation of offenses which were common-law crimes, they won a great measure of popular support. However, as the police have become over-burdened with duties outside the sphere of what people usually consider criminal law enforcement, public support has weakened. These additional duties are often of a minor regulatory nature, rarely produce impressive social benefits, and often prove irritating to the feelings of people who believe they have a right to do as they please. Restrictions and

${ }^{3}$ Pickert, Heinrich A.: Your Security. Detroit Police Department, Detroit, p. 6. 


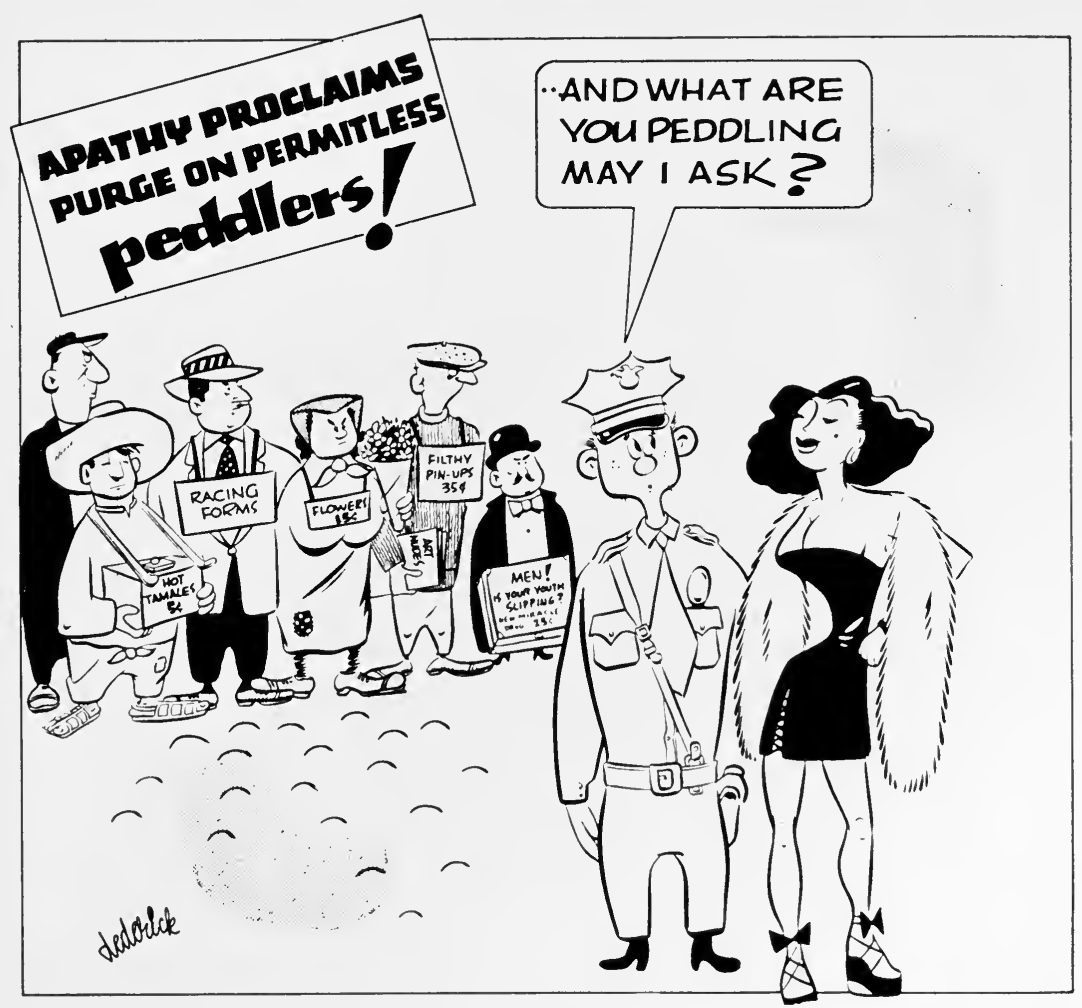

Figure 1. Duties of a Minor Regulatory Nature

complexities of law easily fall into disrepute; and the police, upon whom the administration of law falls, are faced with the disagreeable task of imposing laws upon an often uncooperative and resentful public.

It is unlikely that any single instance of police action has ever been completely satisfactory to everyone concerned; for no matter how efficient or brilliant the example of police work may be, it is not likely to be viewed with enthusiasm by the thwarted or apprehended offender or his family or friends. ${ }^{4}$

Defiance of law and authority is not alone an individual phenomenon. It is practiced by groups as well. The individual, whose activities the policeman may be required to restrict, is often a

\footnotetext{
${ }^{4}$ Massen, John B.: Selling Police Work to the Public. Public Management, 23:135, Chicago, May, 1941 .
} 
symbol of a racial, social, religious, or economic group. To become involved with such an individual is to invite the resentment of the entire group; and it is extremely easy to become involved for most members of minority groups are sensitive and defensive. As a rule, any efforts of the police to control actions of citizens meet with resistance. The American Citizen is a rugged individualist, and strongly resists any effort to control his "freedom." This American individualism, and revolt against authority, is traditional.

No other form of public service is more likely to cause ill-feeling among the public it serves than is the agency whose duty it is to enforce laws and restrict the citizen's activities and control his conduct. Actually, it is the governmental agency which restricts the activities of its citizens; but, so far as the individual is concerned, the government is an abstraction. He regards its symbol-the policeman-as the cause of his troubles; and his resentment is reserved for the officer, and no one else.

Importance of Daily Contacts: Despite the difficulties involved, every effort must be made to create as many favorable contacts as possible between the police and the public because the constantly-accumulating effect, created by these thousands of manto-man contacts, determines the degree of public acceptance or the state of police public relations. Good public relations involves far more than mere saying-it involves doing. It is the common policeman out on his beat, the police officer in a radio car or on a motorcycle, and the desk officer or jailer in the station who make friends or enemies for the department. Though there are other influences involved, the police themselves are the most important factor in determining public attitudes. By building the proper relationships and attitudes between the police and the public, a high degree of acceptance will result and other media affecting public relations, such as the press, radio, moving pictures and fiction writers, will be forced to "get on the band wagon" and do their share toward improving relations between the police and the public. The policies of these media are determined by what the public wants and, consequently, by beliefs and attitudes of the public itself.

Results of Poor Public Relations: If the public relations of the police are not what they should be, unjust charges will be 


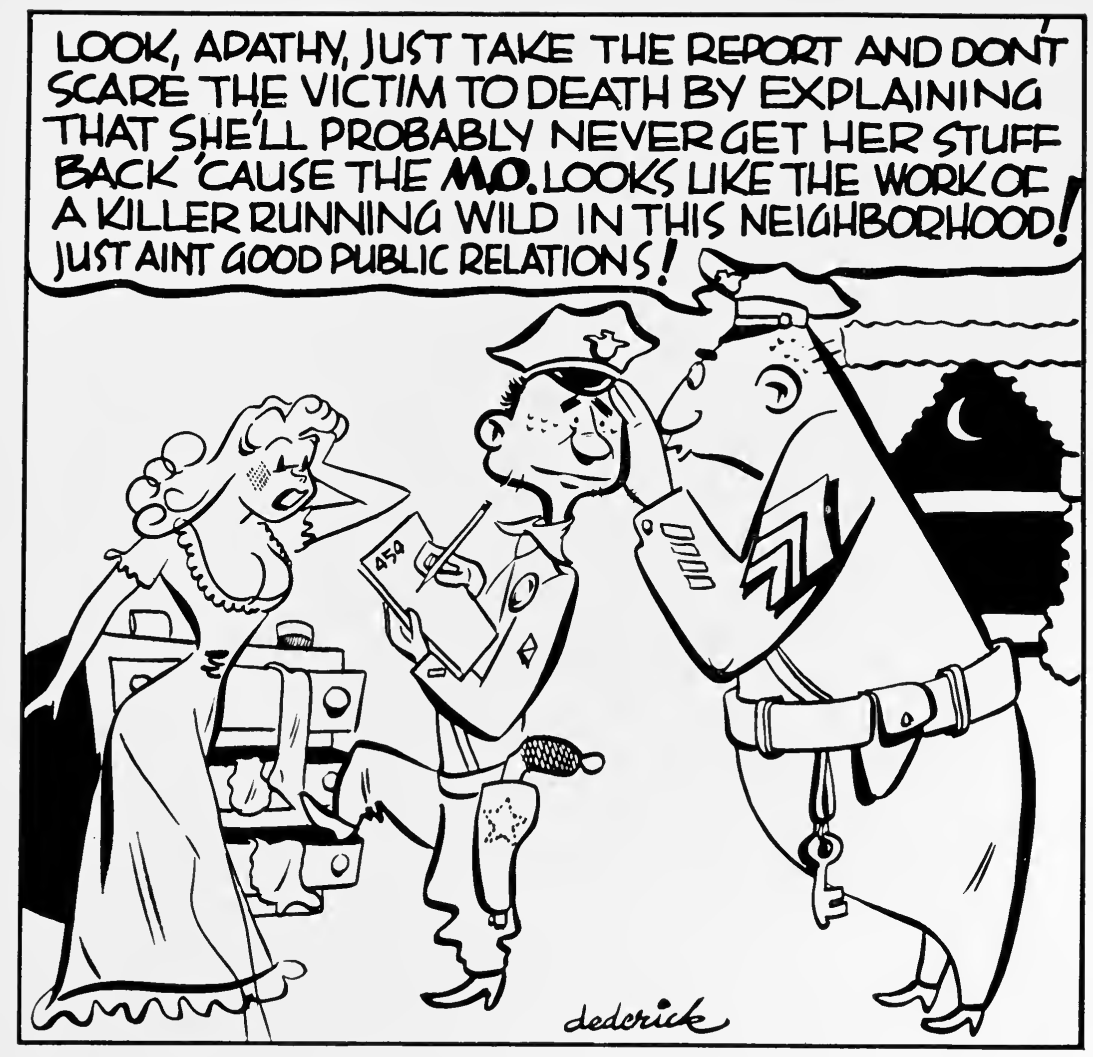

Figure 2. Importance of Properly Handing Plrsonal Contacts

made against them, progressive programs will be impossible, and the police will find themselves in a position where they are fearful of doing anything constructive or progressive because of anticipated resistance by the public. If unfair criticisms are made, it will be because of an improper state of mind and lack of proper attitude on the part of the public. There are many distinct advantages to be gained from maintaining a spirit of free cooperation with the public. When such cooperation exists, police morale will be improved, which, in turn, will lead to increased police effort and improved police service. Difficult programs, which would otherwise be impossible to undertake, then become possible. A general increase in police efficiency will result in still greater appreciation of police, creating a desire on the part of citizens to observe 
laws, comply with regulations, and assist the police in the performance of their functions.

Without such assistance, arrests become difficult, and convictions almost impossible. Without it, the police are held up to ridicule, criticism, and censure at every move. Under such circumstances, the public overlooks no opportunity to make the task of the policeman more difficult and his working conditions more disagreeable. Legislatures are nothing more or less than segments of the public, and reflect its attitudes and beliefs. Legislatures can embarrass the police by passing ill-advised laws, and by refusing to pass laws advocated by law-enforcement agencies. In the court room the most carefully prepared cases may fail because the testimonies of policemen are ignored, or greatly discounted, by jurymen. Juries are, after all, only small parts of the public-at-large. and they naturally reflect current attitudes and prejudices. Under such adverse circumstances, salaries are likely to be reduced rather than increased: days off, vacations, pensions, sick reliefs, and other benefits possessed by the police may be lost either through actual demand by the public or by the administration itself, which may feel it necessary to increase departmental strength by these means in view of the charges of inefficiency hurled by a dissatisfied citizenry. ${ }^{5}$

\section{IMPORTANCE OF THIS STUDY}

If, then, police public relations or contacts are made under such difficult circumstances, and are so extremely important to the successful operation of a police department, it would seem only logical that procedures should be devised to measure the status of public relations at any particular time; and to determine which police techniques, actions, and attitudes are approved-and which are not.

Need for Sound Factual Data: Before an intelligent effort can be made to improve police contacts with the public and, consequently, the citizens' attitudes toward the police, the nature and extent of these attitudes must be known. Although many intelligent estimates have been made by police administrators, and

\footnotetext{
${ }^{5}$ The Police and the Public. Municipal Police Administration. Chicago, The International City Managers Association, 1943, p. 487 .
} 
others, concerning the nature and extent of public attitudes, very little of a scientific nature has been undertaken. This present study was designed to create a device for measuring public attitudes toward the police; and to utilize this device to measure the attitudes of local residents toward the Los Angeles Police Department.

Organization of Material: The present chapter will be followed by Chapter II, in which will be discussed previous attitude surveys in the police and related fields; Chapter III, detailing the research methods and sources of data; Chapter IV, evaluating respondents' replies by the biological factors of age and sex; Chapter VI, considering the responses according to the sociological factors of nationality, marital status, education, and length of residence; Chapter VII, pointing out the effects of occupation upon the citizens' attitudes, and Chapter VIII, summarizing the entire research project.

The bibliography contains, in addition to the works used in the preparation of this manuscript, references to books, articles, and pamphlets pertaining to the field of police public relations. The bibliography is incomplete; but in a field in which the literature is so meager, it should prove of substantial value to students and administrators. 


\section{Chapter II}

\section{PREVIOUS ATTITUDE SURVEYS}

\section{ORIGINS OF PUBLIC OPINION POLLS}

A

LTHough preceded many years by market and consumer surveys, the origins of public opinion polls go back to the first part of the Twentieth Century. The first polls were conducted by newspapers, confined to a local area, and frequently biased. The Farm Journal was probably the pioneer of opinion polls on a national scale, starting in 1912. This was followed by the Literary Digest Polls-which proved very wrong in the 1936 elections. Three polltaking organizations came into existence about this time, founded by research men with experience in sampling methods. These organizations were headed by Elmo Roper, Archibald Crosley, and George Gallup.

The most characteristic feature of Roper's technique is the use of attitude scales. Under this technique, the person being interviewed is given four or more statements, and asked to indicate which most nearly represents his opinion or attitude.

Although Gallup has become the universally-accepted symbol for the public opinion polls, his was neither the first of the modern polls nor the most accurate. Gallup owes his eminence in the public's eye to his journalistic presentation of the results. To achieve public acceptance of his results, he emphasizes simplicity by using questions which require simple "Yes" or "No" answers.

Crosley has generally held that exact measurement is secondary to prediction, or the decisions and actions to be taken as a result of the research. He, therefore, considers many factors other than attitudes. $^{1}$

\section{CRITICISMS OF POLLS AND POLLSTERS}

Claims made, and methods employed, by the takers of polls and attitude surveys, have been criticized by many persons; but, prob-

\footnotetext{
${ }^{1}$ Blankenship, Albert B.: How to Conduct Consumer and Opinion Research. New York, Harper \&. Brothers, 1946, p. 289.
} 
ably, most vehemently and thoroughly by Lindsay Rogers ${ }^{2}$ in The Pollsters. In this book he advances the following arguments:

1. Public opinion is not the sum of answers that people are willing to give to strangers.

2. The intensity of the "Yeas" and "Nays" cannot be measured.

3. Opinion, like beauty, cannot be measured.

4. It is impossible to frame unbiased and unambiguous questions.

5. The often large percentage who have no opinion is frequently ignored in reporting the results.

Most of these arguments can be disposed of by pointing out that-as imperfect as the techniques are, they are better than no techniques; they serve a useful purpose; and, in most cases, are sufficiently reliable. In the present study the objections are further overcome by the techniques described in Chapter III.

\section{PARRATT'S CONTRIBUTION}

Efforts were made, utilizing the so-called "Thurstone Method," by Herman C. Beyle and Spencer D. Parratt, ${ }^{3}$ in 1933 , to determine what citizens think of the third degree; and by Spencer D. Parratt, ${ }^{+}$Professor of Political Science at Syracuse University, in 1937, to determine what citizens think about police behavior.

This type of attitude scale consists of a number of statements intended to reveal the presence of the attitude in question in varying degrees. Statements are selected which indicate a range from extreme preference to extreme rejection on the specific matter in question. The arrangement of these questions so that numerical values can be attached to them then becomes the principal problem. This is done by submitting them to a jury which ranks them in order. The value of each item, or statement, is the central tendency of the jury ratings. Since there is rarely complete agreement as to the significance of each statement, the value of each is

\footnotetext{
${ }^{2}$ Rogers, Lindsay: The Pollsters. New York, Alfred A. Knopf, Inc., 1949, 239 pp.

${ }^{3}$ Beyle, Herman C. and Parratt, Spencer D.: Measuring the Severity of the Third Degree. The Journal of Criminal Law and Criminology, 24:485, July-August, 1933. ${ }^{4}$ Parratt, Spencer D.: A Scale to Measure Effectiveness of Police Functioning. Journal of Criminal Law and Criminology, 28:739-56, January-February, $193^{8}$.
} 
somewhat ambiguous, and the ambiguity of the statement is measured by the dispersion of the ratings. The statements selected are arranged in a linear order to make up the scale. A person's attitude toward the topic in question-all the way from a high positive to a high negative-is determined and given a numerical rating as a result of his checking the scale statements which are acceptable and unacceptable to him.

Professor Parratt, in his work, first questioned 45 citizens concerning their attitudes toward police in general. As a result of this first questioning, two things became apparent: First, there were such differences of attitudes toward the police in various governmental levels that, to obtain an accurate picture, it would be necessary to confine such a survey to one particular level or jurisdiction; and second, attitudes toward the police should be broken down into attitudes toward police activities and traits.

The seven questions asked of the second group, therefore, were as follows: What is your opinion of the Police Force as to-

1. Characteristics of the men composing the Force?

2. Their dealings with minorities?

3. Their dealings with suspicious criminals and witnesses?

4. Their efficiency or skill in preventing or suppressing crime?

5. Their success in suppressing, or their toleration of, vice?

6. Their influence of, or freedom from, politics?

7. Their methods of dealing with the public and with the press?

The next step was to analyze the responses of 97 citizens, to the above questions, for common patterns. Whenever responses appeared to have re-occurred three or more times, a summary statement was written as near to the typical response as seemed practicable. From this analysis, 473 statements were developed and were presented to 21 graduate students in political science and public administration, who checked them for ambiguous statements and unnecessary duplications. From this list, 342 were retained. The next step involved the placing of these $34^{2}$ statements into 11 , equally-appearing intervals, with the hypothetical neutral position at the middle point. From these statements, as distributed on the scale, 126 were selected so as to provide contrast statements, insofar as possible, in every classification or characteristic de- 


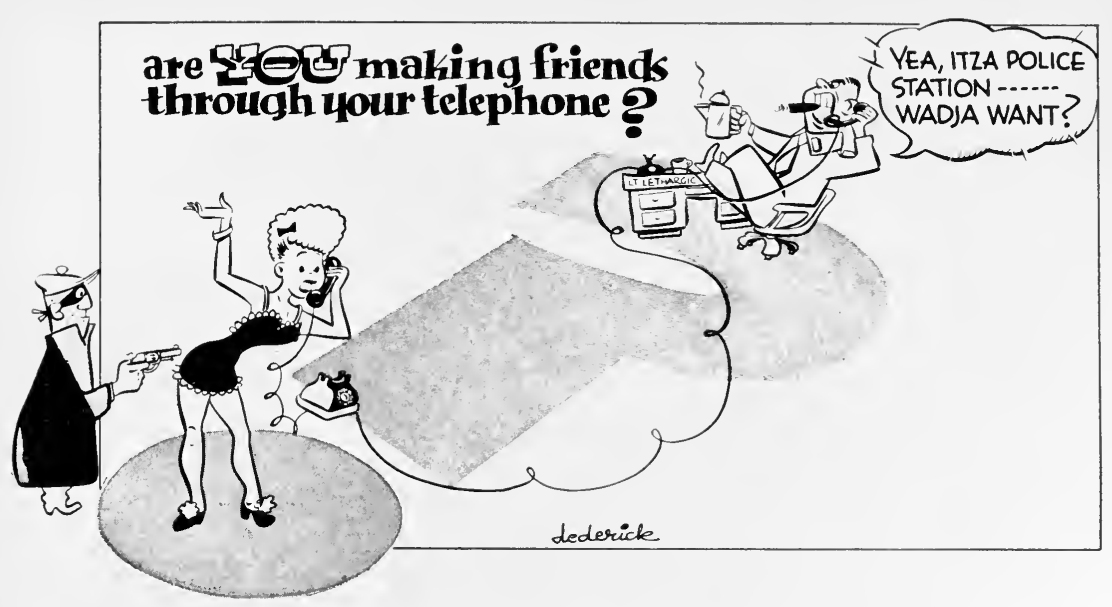

Figure 3 A and 3 B. Telephone Manners

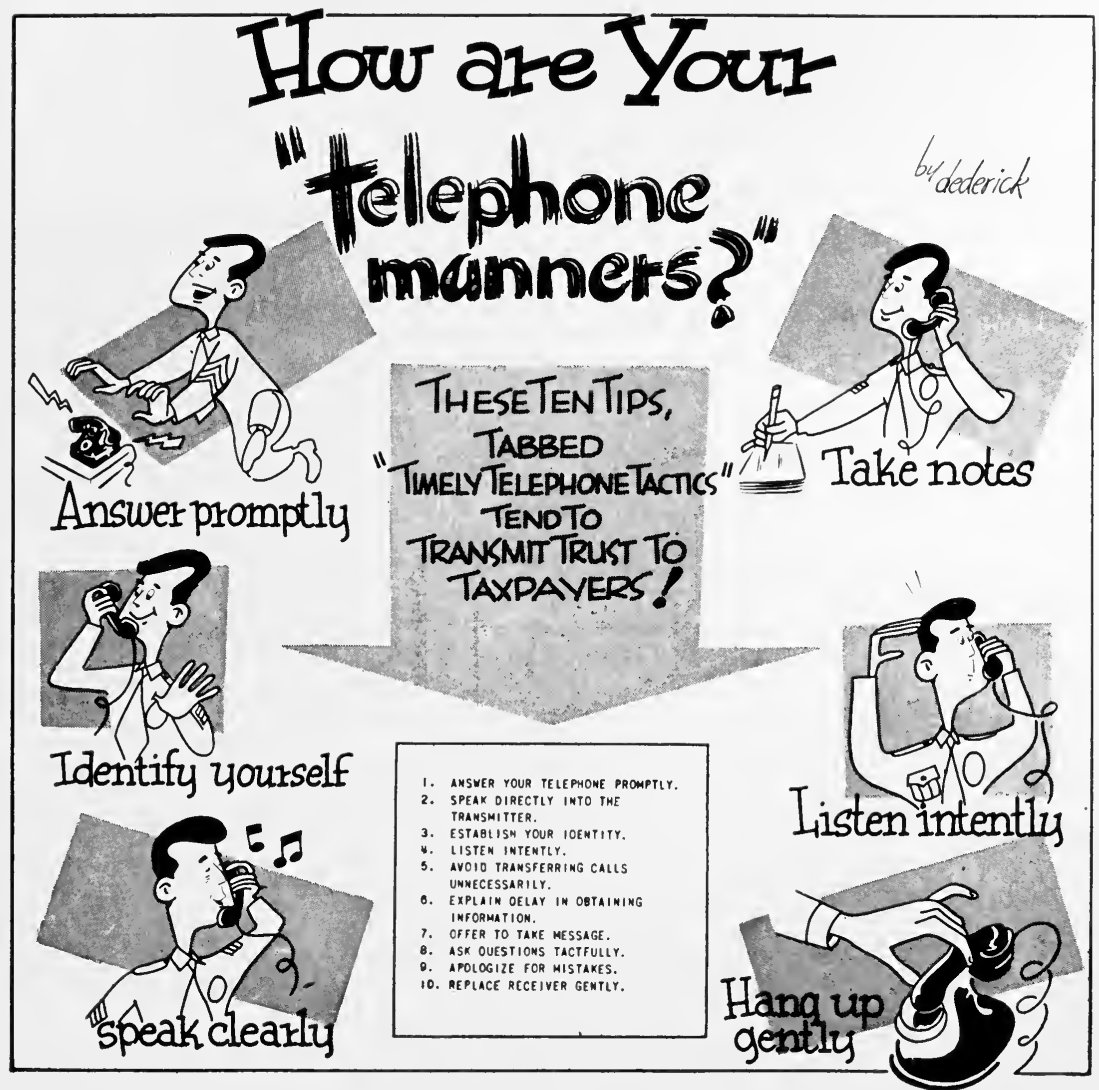




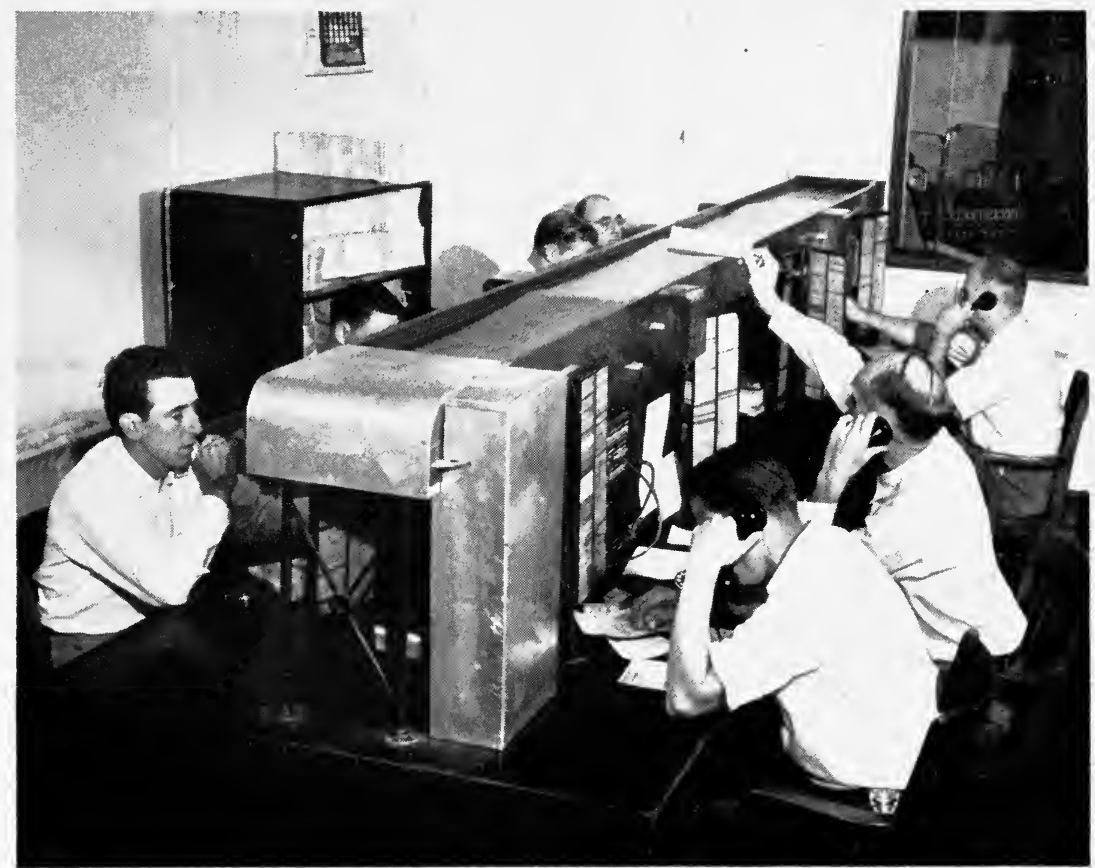

Figure 4. Complaint Board, Los Anghles Police Departmint

Here telephone messages are received and relayed, if indicated, via an endless belt, to the "Mike Room" for transmission to police "Radio Cars." In an emergency, the telephone call can be switched directly to the "Mike Room."

scribed. This scale, which included an approximately equal number of statements evaluated as contributing to the effectiveness of the police and statements rated as hindrances, was then ready for use in measuring the level of public acceptance of a given police department.

\section{POLICE AND ANTI-LYNCH LEGISLATION}

In January, 1938, the American Institute of Public Opinion conducted a poll on specific provisions of the Wagner-Van Nuys Bill, which proposed to make lynching a Federal crime. ${ }^{5}$ The results of this sampling referendum showed that the Country endorsed the bill which would give the Federal Government power to:

"America Speaks (A News release). American Institute of Public Opinion, January $20,193^{8}$. 
1. Fine and imprison local policemen who were negligent in protecting a prisoner from a lynch mob.

2. Make counties in which a lynching occurred pay a fine up to $\$ 10,000$ to the victim or his family.

For the Nation as a whole, a majority-53 per cent-voted in favor of the bill. The New England, Middle Atlantic, East Central, and West Central Sections all returned majorities for the legislation.

The comments received from the voters in the survey clearly indicated that it was the second part of the Wagner-Van Nuys Bill which most offended the public. The majority of those who opposed the bill were against a Federal fine on a county in which a lynching is perpetrated. Most comments, on the other hand, were favorable to the first part of the bill; that is, the section which sought to give the Federal Government the right to punish local policemen who were negligent in protecting a prisoner from a lynching mob. As a justification for this belief, a number of voters pointed out that the Federal Government is responsible for enforcing the Fifteenth Amendment, which guarantees that no person shall be deprived of life without due process of law.

\section{ATTITUDES TOWARD TRAFFIC}

Although very few efforts have been made to determine citizens' attitudes toward policemen, several studies have been undertaken to learn the public's attitudes toward specific phases of law enforcement. Among these is a public opinion survey on traffic problems made by John B. Massen, ${ }^{6}$ in Evanston, Illinois, in 1940. He was assisted by a technical staff of market research analysts and students from Northwestern University's political science and sociology classes. The research technique was not reported other than the fact that two questionnaires were submitted to separate groups of three hundred persons, carefully selected so as to provide a cross-section of the population, in order to measure public opinion toward the police department in the traffic court. Results of the first questionnaire showed concealed enforcement-that is,

\footnotetext{
${ }^{6}$ Massen, John B.: Selling Police Work to the Public. Public Management, 23:13538, May, $194^{1}$.
} 


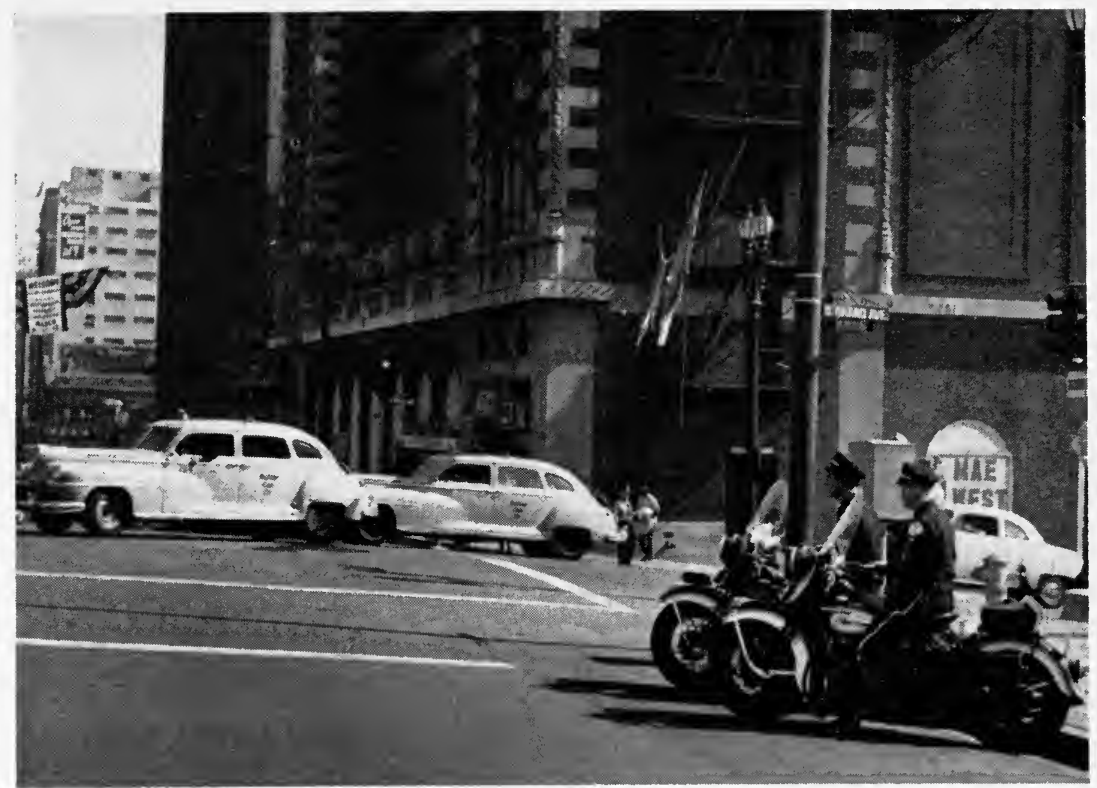

Figure 5. Sitting, IN

Citizens are not so apt to object when the officer is in the open. They do strongly object to concealed enforcement; that is, where the officer is not clearly visible.

officers watching from a concealed or partially hidden locationto be unpopular. In the second questionnaire, with which was furnished information as to the reason for the concealed enforcement, three out of four persons felt it to be justified-thus indicating that an educational campaign would be fairly successful in securing wider acceptance of this policy. Other subjects covered by the surveys were: Booking Violators at Police Stations, Punishment of First Offenders, Punishment of Drunken Drivers, and Courtesy of Officers.

\section{ATTITUDES TOWARD CIVIL SERVICE}

Although not directly in the police field, a survey was conducted, in 1940 , by Robert S. Avery, ${ }^{7}$ Northwestern University, as to the attitudes of residents of Evanston, Illinois, toward the activities of

${ }^{7}$ Avery, Robert S.: Civil Service and Citizen Opinion. National Municipal Review, $X X X: 412-27$, July, 1941 . 
their Civil Service Commission. As many police departments come under Civil Service regulations, this survey is considered pertinent. The objectives of the survey were three in number:

1. To determine whether or not the people of Evanston were in favor of Civil Service for City employees, and to ascertain whether or not they were well enough informed about Civil Service to be able to express intelligent opinions concerning it.

2. To determine whether or not the public believed that City government was likely to be more honest and more efficient if its employees were placed under Civil Service.

3. To determine the extent to which the public was informed about the actual work of the Evanston Civil Service Commission, and whether reaction to its work was favorable or unfavorable.

Techniques Employed: The sampling technique used to arrive at a representative cross-section of the City was similar to that employed by Dr. George Gallup in his public opinion polls. The sample was set up, proportionally, according to six factors: Age, Sex, Political Affiliation, Economic Status, Race, and Population by Voting Precincts.

Several questionnaires were drawn up, and discussed before a graduate seminar in public administration, before one was finally decided upon for use in this survey. Even then, the one selected was given a pre-sampling test in order to eliminate flaws in phraseology, etc., that might make interpretation difficult. The personalinterview technique was employed, in preference to a questionnaire sent out by mail, as a further precaution to insure that men and women in all walks of life would be represented in the sample. The following questions were asked:

1. Do you think that Civil Service for city employees is a good thing?

2. Do you think that all employees of the City of Evanston should be under Civil Service?

3. In this question, all classes of employees engaged by the City were listed and the respondents permitted to state which they thought should be classified under Civil Service. 
4. Does Civil Service insure honesty in City government; or does corrupt politics, working behind the scenes, overshadow all efforts toward honest administration?

5. In general, are you satisfied or dissatisfied with the work being done by the Evanston Civil Service Commission?

General Conclusions: The general conclusions reached in this survey are: that Civil Service is understood, primarily, as a theoretical concept relating to efficiency in government, as contrasted with administration based upon the spoils or patronage system; and beyond this point the public knows very little. When pinned down to phrases concerning the facts and operation of Civil Service in their own city government, the public acknowledged its lack of information necessary to form an opinion. Apparently, the principles of Civil Service, based upon a merit system, have not been brought sufficiently before the public.

Mr. Avery feels that it is discouraging to discover that, in a City such as Evanston, the general public knows so little about the work of its own Civil Service Commission. He feels that it is the task of Civil Service to continue to educate the public in the theory and practice of Civil Service Administration, and that there must be far greater emphasis placed upon this factor, in the future, until the public is made alert and interested in the problem. Then -and only then-he feels, can the influence of the public be made the wholesome and vitalizing force it should be.

\section{ATTITUDES TOWARD TRAFFIC SAFETY}

Between August 22, 1945, and September 5, 1945, the Opinion Research Corporation conducted, for the National Safety Council, a Public Opinion Survey based on a national sample of 2917 personal interviews with persons twenty-one years of age and older. ${ }^{8}$

Techniques Employed: A representative cross-section of the Nation's population was selected. Interviewing was done in all of the forty-eight states and the District of Columbia. Representatives included men and women, rich and poor, urban and rural residents, drivers and non-drivers, etc., in about the same proportion

${ }^{8}$ The Public's Attitude on Traffic Safety. Princeton, New Jersey, Opinion Research Corporation, 1946, $79 \mathrm{pp}$. 
that they occur in the Nation's population, with the exception of occupation. The sample included a somewhat higher proportion of white-collar workers than occurs in the national population, and a correspondingly lower proportion of skilled workers.

In order to bring the occupational distribution of the sample into line with the total population, the sample was weighted. This was done by duplicating $74^{2}$ punched cards of skilled workers, manual workers, and farmers and adding them to the sample. This weighting method gave a total of 3659 tabulating cards, and made the sample conform to the occupational distribution of the national population.

The total number of cases used in the tables is the "weighted total." Results of this weighting procedure are shown in Table I.

Survey Findings: The findings of this survey are of such importance to law enforcement officers that they are quoted in part:

1. The public is acutely conscious of the traffic accident PROBLEM AND IS ACTIVFIY INTERESTED IN ITS SOLUTION.

Therefore, state and local officials and their organizations, as well as private organizations, can make their plans for the future with the assurance of a favorable public attitude. Note the following:

a. Ninety-four people out of every 100 say that they think traffic accidents are a "serious problem."

$5 \%$ say they are not serious.

$1 \%$ say they "don't know."

b. And the public expects the problem to become more serious.

$77 \%$ say they think there will be more traffic accidents in the next year or two than there are now.

$18 \%$ think there will not be any more.

$5 \%$ have no opinion.

In anticipating this increase in accidents, the public is thinking mainly of the increased traveling and faster driving resulting from the end of gas rationing and the rundown condition of cars.

c. But the people do not take a hopeless view of the traffic accident problem. Three out of every five believe the number of traffic accidents can be reduced. 
TABle I

STRATIFICATION OF THE SAMPLE, SHOWING RELATION TO TOTAL POPULATION BEFORE AND AFTER WEIGHTING IN TRAFFIC SURVEY

\begin{tabular}{|c|c|c|c|}
\hline & $\begin{array}{c}\text { Before } \\
\text { Weighting }\end{array}$ & $\begin{array}{c}\text { After } \\
\text { Weighting }\end{array}$ & Nation \\
\hline Number of cases & 2917 & $3^{6} 59$ & \\
\hline White-collar workers & $42 \%$ & $33 \%$ & $33 \%$ \\
\hline Skilled workers & 23 & $3^{6}$ & $3^{6}$ \\
\hline Manual workers & 16 & 15 & 15 \\
\hline Farmers & 19 & 16 & 16 \\
\hline \multicolumn{4}{|l|}{$\operatorname{Sex}$} \\
\hline Men & $44 \%$ & $45 \%$ & $43 \%$ \\
\hline Women & $5^{6}$ & 55 & 57 \\
\hline \multicolumn{4}{|l|}{ Age } \\
\hline Under $3^{\circ}$ years & $19 \%$ & $19 \%$ & $23 \%$ \\
\hline $3^{0-44}$ years & 35 & 35 & 33 \\
\hline 45 years and over & $4^{6}$ & $4^{6}$ & 44 \\
\hline \multicolumn{4}{|l|}{ Income } \\
\hline Upper income & $15 \%$ & $13 \%$ & $16 \%$ \\
\hline Middle income & 57 & $5^{6}$ & 49 \\
\hline Lower income & 28 & $3^{1}$ & 35 \\
\hline \multicolumn{4}{|l|}{ Race } \\
\hline White & $91 \%$ & $91 \%$ & $90 \%$ \\
\hline Colored & 9 & 9 & 10 \\
\hline \multicolumn{4}{|l|}{ City Size } \\
\hline Farm & $20 \%$ & $18 \%$ & $20 \%$ \\
\hline Under 2500 & 20 & 20 & 20 \\
\hline $2500-25.000$ & 16 & 17 & 17 \\
\hline $25,000-100,000$ & 11 & 1.1 & 12 \\
\hline $100,000-500,000$ & 12 & 12 & 13 \\
\hline $5^{00,000}$ and over & 18 & 19 & 18 \\
\hline \multicolumn{4}{|l|}{ Section } \\
\hline New England & $8 \%$ & $8 \%$ & $6 \%$ \\
\hline East & 22 & 23 & 24 \\
\hline Midwest & 32 & 32 & 31 \\
\hline South & 26 & 25 & 28 \\
\hline Mountain & 3 & 3 & 3 \\
\hline Far West & 9 & 9 & 8 \\
\hline
\end{tabular}


TABLE II

ATTITUDE OF RESPONDENTS TOWARD

TRAFFIC LAW ENFORCEMENT

Do you think Traffic Regulations around here ought to be enforced MORE strictly or LESS strictly than they are now

\begin{tabular}{|c|c|c|c|c|c|}
\hline & $\begin{array}{l}\text { Respond- } \\
\quad \text { ents }\end{array}$ & $\begin{array}{l}\text { More } \\
\text { Strictly }\end{array}$ & $\begin{array}{c}\text { About Same } \\
\text { as Now }\end{array}$ & $\begin{array}{l}\text { Less } \\
\text { Strictly }\end{array}$ & $\begin{array}{l}\text { Don't } \\
\text { Know }\end{array}$ \\
\hline \multirow{3}{*}{$\begin{array}{l}\text { Total } \\
\text { Men } \\
\text { Women }\end{array}$} & $3_{5}^{6} 9$ & $71 \%$ & 23 & 1 & 5 \\
\hline & 1669 & $71 \%$ & 24 & 2 & 3 \\
\hline & $199^{\circ}$ & $72 \%$ & 22 & * & 6 \\
\hline \multirow{3}{*}{$\begin{array}{l}\text { Under } 30 \text { years } \\
30-40 \text { years } \\
45 \text { years and over }\end{array}$} & 718 & $70 \%$ & 25 & 1 & 4 \\
\hline & 1286 & $71 \%$ & 24 & 1 & 4 \\
\hline & 1655 & $73 \%$ & 21 & 1 & 5 \\
\hline \multirow{3}{*}{$\begin{array}{l}\text { Upper income } \\
\text { Middle income } \\
\text { Lower income }\end{array}$} & $4^{669}$ & $71 \%$ & 26 & * & 3 \\
\hline & 2056 & $72 \%$ & 23 & 1 & 4 \\
\hline & 1134 & $71 \%$ & 22 & 1 & 6 \\
\hline \multirow{2}{*}{$\begin{array}{l}\text { White } \\
\text { Colored }\end{array}$} & 3332 & $71 \%$ & 23 & 1 & 5 \\
\hline & 327 & $76 \%$ & 17 & 1 & 6 \\
\hline \multirow{2}{*}{$\begin{array}{l}\text { Under } 2500 \\
2500-100,000\end{array}$} & $13^{8} 7$ & $72 \%$ & 24 & * & 1 \\
\hline & 1141 & $69 \%$ & 24 & 1 & 6 \\
\hline Over 100,000 & 1131 & $73 \%$ & 21 & 1 & 5 \\
\hline \multirow{4}{*}{$\begin{array}{l}\text { East } \\
\text { Middle West } \\
\text { South } \\
\text { Far West }\end{array}$} & 1134 & $66 \%$ & 28 & 1 & 5 \\
\hline & 117 & $72 \%$ & 23 & * & 5 \\
\hline & 920 & $78 \%$ & 16 & 1 & 5 \\
\hline & 434 & $68 \%$ & 26 & 1 & 5 \\
\hline \multirow{4}{*}{$\begin{array}{l}\text { White-collar workers } \\
\text { Skilled workers } \\
\text { Manual workers } \\
\text { Farmers }\end{array}$} & 1128 & $72 \%$ & 23 & 1 & 4 \\
\hline & $123^{6}$ & $70 \%$ & 23 & 1 & 6 \\
\hline & $5^{\circ} 4$ & $72 \%$ & 23 & 1 & 4 \\
\hline & $55^{\circ}$ & $74 \%$ & 22 & 1 & 3 \\
\hline \multirow{2}{*}{$\begin{array}{l}\text { Driver } \\
\text { Nondriver }\end{array}$} & $235^{8}$ & $70 \%$ & 26 & 1 & 3 \\
\hline & 1301 & $73 \%$ & 18 & 1 & 8 \\
\hline \multirow{2}{*}{$\begin{array}{l}\text { Have had accident } \\
\text { Have not had accident }\end{array}$} & 1039 & $70 \%$ & 24 & 1 & 5 \\
\hline & 2620 & $72 \%$ & 22 & 1 & 5 \\
\hline \multirow{2}{*}{$\begin{array}{l}\text { Have been arrested } \\
\text { Have not been arrested }\end{array}$} & 881 & $68 \%$ & 27 & 2 & 3 \\
\hline & 2778 & $73 \%$ & 22 & * & 5 \\
\hline \multirow{2}{*}{$\begin{array}{l}\text { Have been "bawled out } \\
\text { Have not been "bawled } \\
\text { out" }\end{array}$} & $t^{\prime \prime} 73^{6}$ & $71 \%$ & 24 & 2 & 3 \\
\hline & 2817 & $72 \%$ & 23 & * & 5 \\
\hline
\end{tabular}

* Less than one-half per cent. 
"Do you think the number of traffic accidents can be cut down, or will there always be about as many as there are now?"

$61 \%$ say they can be cut down.

$28 \%$ say there will always be as many.

$8 \%$ say there will be more.

$3 \%$ say they "don't know."

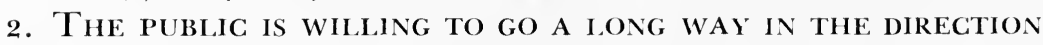
OF ACCIDENT PREVENTION.

Evidence from the survey makes it abundantly clear that measures to decrease traffic hazards will have the support of the public.

As is shown in detail later in this report on question after question having to do with traffic safety, large majorities of the people vote in FAVOR of the things they think will help reduce accidents.

3. In the pUblic's thinking at PRESENT, the bEST WAY TO PREVENT ACCIDENTS IS BY STRICTER ENFORCEMENT.

Over and over again, throughout the survey, people say, "Enforce the regulations," "Fine them," and "Make them obey the law."

This does not mean that the public disapproves of engineering and education measures. As a matter of fact, as shown later in this report, when asked to choose among the three methods the public divides about evenly.

But enforcement is in the forefront of their thinking today (see Table II).

\section{Witness:}

a. Seven out of every 10 people are in favor of stricter enforcement of traffic regulations. Only 1 per cent think regulations are too strictly enforced now.

"Do you think traffic regulations around here ought to be enforced more strictly or less strictly than they are now?" $71 \%$ say more strictly enforced.

$1 \%$ say less strictly enforced.

$23 \%$ say about the same as now.

$5 \%$ have no opinion. 
b. When asked what might be done to cut down accidents in their own community, a majority of the people think first of STRICTER ENFORCEMENT.

$29 \%$ say enforcement should be tightened up.

$12 \%$ say police should eliminate reckless driving.

$7 \%$ say police should clamp down on drunken driving.

$7 \%$ ask for an increased police force.

$5 \%$ say make stricter laws.

$16 \%$ say reduce the speed limit.

Only $9 \%$ say educate the public.

Only $8 \%$ say improve roads and highways.

And $8 \%$ suggest more stop signs and lights.

(Percentages add to more than 100 because some people gave more than one answer.)

c. When asked what might be done to curtail common annoyances of the road, the public suggests enforcement measures.

$22 \%$ say enforce the laws.

$16 \%$ say increase the number of fines and arrests.

$8 \%$ say the police should be more efficient.

$3 \%$ say offenders should be reprimanded for minor offenses.

$8 \%$ say make stricter laws.

$13 \%$ say educate the public.

d. Similarly, enforcement measures are mentioned more frequently than others as a means of preventing "driver accidents."

$18 \%$ say stricter enforcement is needed.

$13 \%$ say eliminate drunken driving.

$5 \%$ say cut down on speeding.

$4 \%$ suggest stricter penalties for careless driving

$5 \%$ say reduce the speed limit.

$16 \%$ say tighten up on driver requirements.

$11 \%$ suggest stricter car inspection.

$10 \%$ suggest education of the public.

$27 \%$ say simply that drivers should be more careful. 


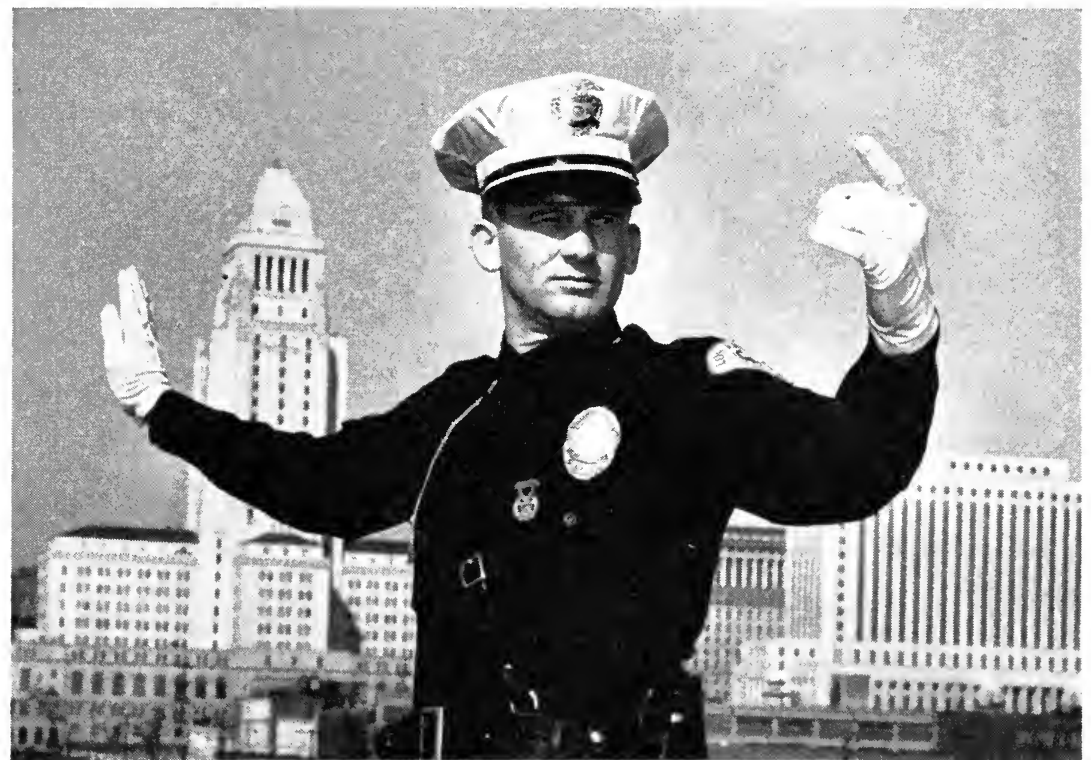

Figure 6. A AND 6B. U Niforil Haid Sigitals

Iniform hand signals increase efficiency of traffic control and are greatly appreciated by the public.

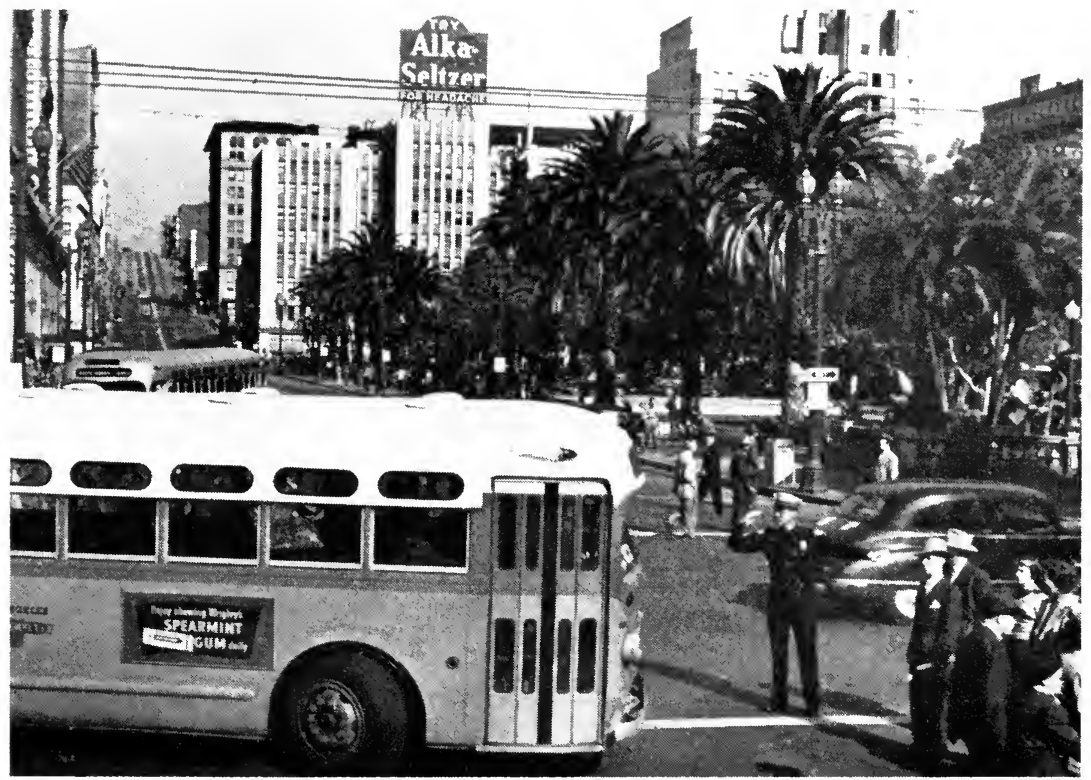


4. Nor is the above mere lip-Service to accident prevention. EVEN THOSE WHO HAVE BEEN ARRESTED OR GIVEN A TRAFFIC TICKET SAY-TWO TO ONE-THAT THEY FELT IT WAS JUSTIFIED AND THAT THEY WERE MORE CAREFUL ABOUT OBEYING THE LAW AFTERWARD.

Almost one fourth of the people-24 per cent-say they have been arrested or given a traffic ticket (including parking tickets) and two thirds of these people-16 per cent of the total public-say they think it was justified. Similarly, the same proportion-16 per cent-say they were "more careful about obeying the law afterwards."

Moreover, the 24 per cent who have been given a ticket vote about the same as the total population for stricter enforcement.

Sixty-eight per cent of these people say traffic regulations should be more strictly enforced, as compared with 71 per cent of the total public.

5. The CONDUCt OF THE POLICE IN MAKING ARRESTS AND GIVING TRAFFIC TICKETS IS APPROVED BY TWO THIRDS OF THE OFFENDERS.

"How did you feel about the way the police handled the matter?"

Very favorable reaction $23 \%$

Moderately favorable $44 \%$

Unfavorable $27 \%$

"Don't remember" $\quad 6 \%$

Similarly, most of those who went to court have a favorable impression of the court's treatment of them. (Over two-fifths of the cases didn't have to go to court.)

"How did you feel about the way the court handled the matter?"

$\begin{array}{lr}\text { Satisfied } & 35 \% \\ \text { Dissatisfied } & 13 \% \\ \text { Other answers } & 8 \% \\ \text { Didn't have to go to court } & 44 \%\end{array}$ 


\section{ATTITUDES OF GERMANS TOWARD THEIR POST-WAR POLICE}

An excellent survey as to the attitudes of German citizens toward their post-war police was made on request of the Civil Administration Division of the Office of Military Government of the United States by the Opinion Survey Branch, Information Service Division, in December, 1948..$^{9}$ This survey also covered the awareness of the Germans as to democratization and decentralization, and their knowledge of civil rights.

Technigues Employed: The sample contained a total of 1900 residents in Amzon, Berlin, and Bremen, and represented a scientific cross-section of the population within these areas. The interviews were made by trained German interviewers supervised by American Field Officers.

Surver Results: As a result of this survey, the following information was obtained:

1. Sixty-four per cent of Amzon respondents say they are satisfied with the present German Police Force, with somewhat higher approval among Berlin and Bremen residents.

2. A plurality-47 per cent-of Amzon respondents also think that the police force today provides as much security and order as in former times, though a large minority has greater praise for past policemen.

3. Among those who think the police force was better in former days, the Nazi Era was more frequently mentioned than any other prior time.

4. Forty-five per cent in Amzon do not think the police should have more authority than they now have. When the 31 per cent who would like the police to have more power in certain areas were asked to specify, the battle against the black market and control over Displaced Persons were most frequently mentioned.

${ }^{9}$ Public Attitudes Toward Post-war German Police. I. General Appraisals. Report No. 166, Opinion Surveys Branch, ISD, OMGUS A PO 807. Bad Nauheim, Germany. Mimeographed $8 \mathrm{pp}$.

Public Attitudes Toward Post-war German Police. II. Awareness of Civil Rights Versus Police Powers. Report No. $1_{7}$, Opinion Surveys Branch, ISD, OMGUS A PO 807 . Bad Nauheim, Germany. Mimeographed 9 pp. 
5. Only a very few respondents-4 per cent-in Amzon, name areas in which they think the police have too much authority at present.

6. Six in 10 Amzon respondents do not want members of the police force to take an active part in political life.

7. Fifty-five per cent in Amzon think that policemen should not run for a public office. Bremen and Berlin figures are not quite so high.

8. It is the opinion of half of Amzon respondents that members of the present police force are not drawn from any particular population groups. A strong majority also feel that the members of the police force should be evenly drawn from all parts of the population.

9. When asked whether or not they think the local police should be under the Ministry of the Interior, Bavaria and Wuerttemberg-Baden residents tend more frequently to favor decentralized control, while in Bremen and Hesse a plurality more often favor control at the Land Level. High "No Opinion" figures show that people are not wellacquainted with the issue involved.

10. Only one person in 20 in Amzon says he is aware of provisions in his Land Constitution designed to protect him from arbitrary use of police power, and still fewer can name a specific provision for this purpose.

11. Nevertheless, large majorities-between 80 and go per centhave a sensible proposal as to what they would do if they felt that the police had violated their rights.

12. About six people in 10 in Amzon (more in Berlin and Bremen) are aware that a policeman off duty is "just another citizen" and is not vested with any particular authority.

13. Over three-quarters of the people in the American Zone think that the police have a right to search a private dwelling without a warrant merely on suspicion that a suspect may be there. This despite specific prohibition of such search in all Laender Constitutions. When the question on the right to search a dwelling without a warrant is loaded a little, only 8 per cent can be found who will declare that a citizen has the right to refuse permission for a search. 
14. The new German Police are not permitted to levy on-thespot fines. The police and judiciary are kept sharply separate. Yet, when asked about a hypothetical case in which a policeman levied such a fine, less than half of the people knew that he was exceeding his authority.

15. On the other hand, over half the people in Amzon are aware of a suspect's right to be brought before a judge within a reasonable period of time after arrest.

16. Even more are unaware that a police chief has no right to break up a peaceful public meeting on the grounds that he doesn't like the sentiments expressed there.

17. Finally, about six in 10 are aware that a police chief is not authorized to pre-censor newspaper editorials of which he disapproves.

18. In all these cases of civil rights, certain population groups stand out as most aware of the citizens' rights. These are the better educated, the upper classes, the young, the men, and the people in Berlin and Bremen.

19. Conversely, the greatest ignorance of the rights of citizens, or the greatest deference to authority, is found among the uneducated, the lower classes, the elderly, the women, and the Bavarians.

\section{THE AMERICAN SOLDIER IN WORLD WAR II}

No résumé of research on attitudes would be complete without at least a passing reference to the monumental, four-volume work on the attitudes of the American Soldier in World War II. ${ }^{10} \mathrm{Al}$ though not directly in the police field, these volumes are a rich source not only of actual attitudes, but also of methodology. They are the product of the four-year activity of the Research Branch, Information and Education Division, of the United States Army.

In many ways, it is a unique record because never before had modern methods of social science been employed on so large a scale by such competent technicians. Its value should prove great, not only to the military, but also to social scientists and students.

\footnotetext{
${ }^{10}$ U. S. Army (Research Branch Information and Education Division). The American Soldier. Vols. I, II, III, and IV. Princeton, Princeton University Press, 1949.
} 


\section{Chapter III}

\section{RESEARCH METHODS AND SOURCES OF DATA}

\section{SURVEY TECHNIQUES}

A frer a thorough evaluation of the various survey and polltaking techniques available, it was decided to use for this study a combination of the multiple-choice or "cafeteria" question used by Roper, and the open-question or free-answer response used by John D. Gerletti. ${ }^{1}$

The multiple-choice question is one which presents several possible answers in an attempt to obtain a graded response. The type selected for the study consists of a series of four statements from which the respondent is to select the one which most nearly represents his opinion or attitude. The advantages of this method are that the results are easily tabulated, the number of respondents who claim to have no opinion is reduced, and replies indicate the intensity of the respondents' feelings. The disadvantages are the difficulty of establishing clear-cut alternatives and the danger of irritating the respondent.

The Opfn-Question or Free-Answer Response: The openquestion or free-answer response is one in which the respondents are given an opportunity to say what they think in their own words rather than being forced to choose between suggested answers. This technique has great value in exploration; that is, to discover problems or attitudes that have not been foreseen. By this method, the danger of suggesting plausible answers to the respondent is avoided, and it results in a much fuller understanding of the respondents' attitudes because the reasons for the attitudes are often given. The disadvantages of this survey method are that it requires more time and effort of the enumerators and the respondents, and may result

\footnotetext{
${ }^{1}$ Gerletti, John D.: A Problem Analysis of the Work of the Juvenile Officer for the Purpose of Developing Materials for an In-Service Training Program. A Doctoral Dissertation. University of Southern California, 1949.
} 
in a large percentage that refuse to answer or claim that they have no opinion. These replies are also very difficult to tabulate. ${ }^{2}$

Advantages of Techniques Selected: It was felt that the advantages and disadvantages, and the strength and weaknesses, of these two techniques would supplement and offset each other in the present study. The criticisms made by Lindsay Rogers, ${ }^{3}$ and others, were to a large extent overcome by:

1. A job of salesmanship by the enumerators to convince the respondents that it was to their advantage to report accurately and truthfully.

2. Multiple-choice answers allowing more than a mere "Yes" or "No"; that is, some range of intensity of feeling.

3. Questions having been tried out on many people and their average verdicts tabulated.

4. The percentage of "Do Not Knows" being reported in each case as it is considered as important as any of the other answers in this type of survey.

It is believed that any differential in external factors, (that is, press releases, etc.), taking place during the period covered by the present survey, has been adequately compensated for, and nullified by, the large size of the sample used-3100 cases.

Background Information: A list of personal data, or background information, such as sex, nationality, age, occupation, etc., was included for two reasons: (1) So as to be able to make comparative studies among the various classes and groups indicated; (2) So as to be able to select a representative sample or "universe" based on a "quota system"; that is, to select groups of people in the same age, sex, nationality, and economic groups, and in the same proportion as they appear in the community. The fundamental principle of scientific sampling is simply that a sample must be representative; that is, as near as possible a model of the total population to be sampled and paralleling the larger group in all of its major proportions. The question of size of the sample is of secondary consideration.

${ }^{2}$ Blankenship, Albert B.: How to Conduct Consumer and Opinion Research. New York, Harper and Brothers, 19.6, p. 278 .

${ }^{3}$ Rogers, Lindsay: The Pollsters. New York, Alfred A. Knopf, Inc., 1949, 239 pp. 


\section{METHOD OF STRATIFICATION}

There are two general methods of drawing representative samples: taking a purely random selection, and building a sample as a working model of the larger group on the principle of stratification. This latter method of stratification has been followed in the present study; but, contrary to the customary method of making the stratification before contacting the respondents, the participation of a large number of persons was solicited in groups and the stratification later made by machine methods, based upon information reported by Eshref Shevky and Marilyn Williams in The Social Areas of Los Angeles. ${ }^{4}$

Composition of Los Angeles Population: As a result of their research, these authors have determined what kind of people live in Los Angeles and just where they live. They point out that this is a highly urban center in one of the most urban states in the Country; that it is a "white-collar" town; that, compared with other parts of the Country, this city has a larger proportion of population in the middle and later years, and a smaller proportion in the very young age bracket; and that it is a community built up of migrants from all parts of the Nation.

"Social Areas": Shevky and Williams devised a yard stick for measuring these people, and for assigning them to nine "Social Areas." Measurement is done in terms of social rank and urbanization. Three factors are combined to form social rank. These are: (1) level of occupation; (2) level of education; and (3) level of income. These three are inter-related and tend to move together. The three measures of urbanization are: (1) fertility, or the number of children under five years of age for each thousand women in the child-bearing ages; (2) the proportion of women in the labor force; and (3) the occupancy of single-family dwelling units. Like the three components of social rank, these three factors tend to move together. Social rank is divided into three levels-low, middle, and high. Urbanization is also divided into three segments-low, middle, and high. By arranging these factors as indicated by the chart, Figure 7 , nine social areas result-each having a certain de-

\footnotetext{
${ }^{4}$ Shevky, Eshref and Williams, Marilyn: The Social Areas of Los Angeles. Berkeley, University of California Press, 1949, $172 \mathrm{pp}$.
} 


\section{URBANIZATION}

HIGH

AVERAGE

LOW

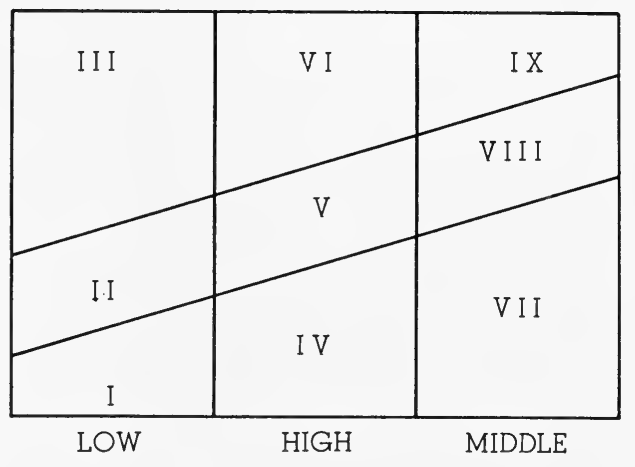

\section{SOCIAL RANK}

Figure 7

Social Areas of Los Angeles by Social Rank and Urbanization

(Diagram from Social Areas of Los Angeles)

gree of social rank and a certain degree of urbanization. The "Social Areas," are not geographically continuous; segments of each appear at various locations throughout the city.

On the basis of census data, the position of each census tract was rated as low, average, or high social rank; and low, average, or high level of urbanization. By combining homogeneous tracts, nine social areas were created. These range from Area I-with low social rank and low level of urbanization-to Area IX-with high social rank and high level of urbanization. All figures are averages, and their use is primarily a descriptive one to indicate general placement within the total framework. Obviously, not all the people in every tract within a single social area have the same level of education, income, etc. The figure merely indicates the tract's position when compared with other tracts.

Conversion of Postal Zones to "Social Areas": For the present study postal zones, which were asked for in the questionnaire, were converted to "social areas" by combining census tracts. This was done by transposing a postal zone map onto a census tract map. Where more than one social area was represented in a given 
postal zone, a subjective determination of the social area to be assigned to a given respondent was made on the basis of other information given; that is, occupation, education, and race.

Composition of Los Angeles by Social Area, Sex, Age, and Nationality: From publications of the Haynes Foundation ${ }^{5}$ and the Welfare Council of Metropolitan Los Angeles, ${ }^{6}$ the current percentage of Negroes and Mexicans in Los Angeles was determined to be 11 per cent and 7.6 per cent respectively. These figures were combined with information contained in Social Areas of Los Angeles ${ }^{7}$ to form Table III, which shows the composition of Los Angeles broken down by social area, sex, age, and nationality.

Table III

POPULATION COMPOSITION OF LOS ANGELES BY SOCIAL AREA, SEX, AGE, AND NATIONALITY

\begin{tabular}{|c|c|c|c|c|c|}
\hline Area & $\begin{array}{c}\% \text { of City } \\
\text { in Area }\end{array}$ & $\begin{array}{c}\% \text { of Men } \\
\text { in Area }\end{array}$ & $\begin{array}{l}\% \text { of People } \\
50 x \text { in Area }\end{array}$ & $\begin{array}{c}\% \text { of Neg. } \\
\text { in Area }\end{array}$ & $\begin{array}{c}\% \text { of Mex. } \\
\text { in Area }\end{array}$ \\
\hline I & 1.3 & 51.0 & 27.8 & .2 & .2 \\
\hline II & 12.7 & 19.5 & 25.2 & 2.2 & $3 \cdot 3$ \\
\hline III & 1.1 & 59.8 & 27.8 & $\cdot 3$ & .5 \\
\hline IV & 6.8 & 49.5 & $25 \cdot 4$ & .1 & .6 \\
\hline $\mathrm{V}$ & 45.3 & 47.1 & 24.1 & $5 \cdot 5$ & 2.1 \\
\hline VI & 14.6 & 43.2 & $37 \cdot 7$ & 2.1 & .8 \\
\hline VII & 2.5 & 44.8 & $3^{8.7}$ & .1 & .0 \\
\hline VIII & 12.1 & 43.2 & 26.1 & $\because 5$ & .1 \\
\hline IX & $3 \cdot 3$ & $43 \cdot 5$ & $3^{8.7}$ & .0 & .0 \\
\hline TOTAL & 100 & $\overline{19.2}$ & $3^{0.3}$ & 11.0 & 7.6 \\
\hline
\end{tabular}

Stratified SAMPle or “Universe”: By using the information set forth in this table, it was possible to prepare a stratified sample, or "universe," which was a very accurate miniature of the total

${ }^{5}$ Hanson, Earl and Beckett, Paul: Los Angeles: Its People and Its Homes. Los Angeles, The Haynes Foundation, 1944.

Shevky, Eshref and Lewin, Molly: Your Neighborhood. Los Angeles, The Haynes Foundation, 1919, p. 10.

${ }^{6}$ Frank, Elizabeth R.: Background for Planning. Los Angeles, Research Department, Welfare Council of Metropolitan Los Angeles, 1949, p. $3^{6 .}$

${ }^{7}$ Shevky, Eshref and Williams, Marilyn: The Social Areas of Los Angeles. Berkeley, University of California Press, 1949, 172 pp. This study was made and published under the auspices of The John Randolph Haynes and Dora Haynes Foundation, Los Angeles. 


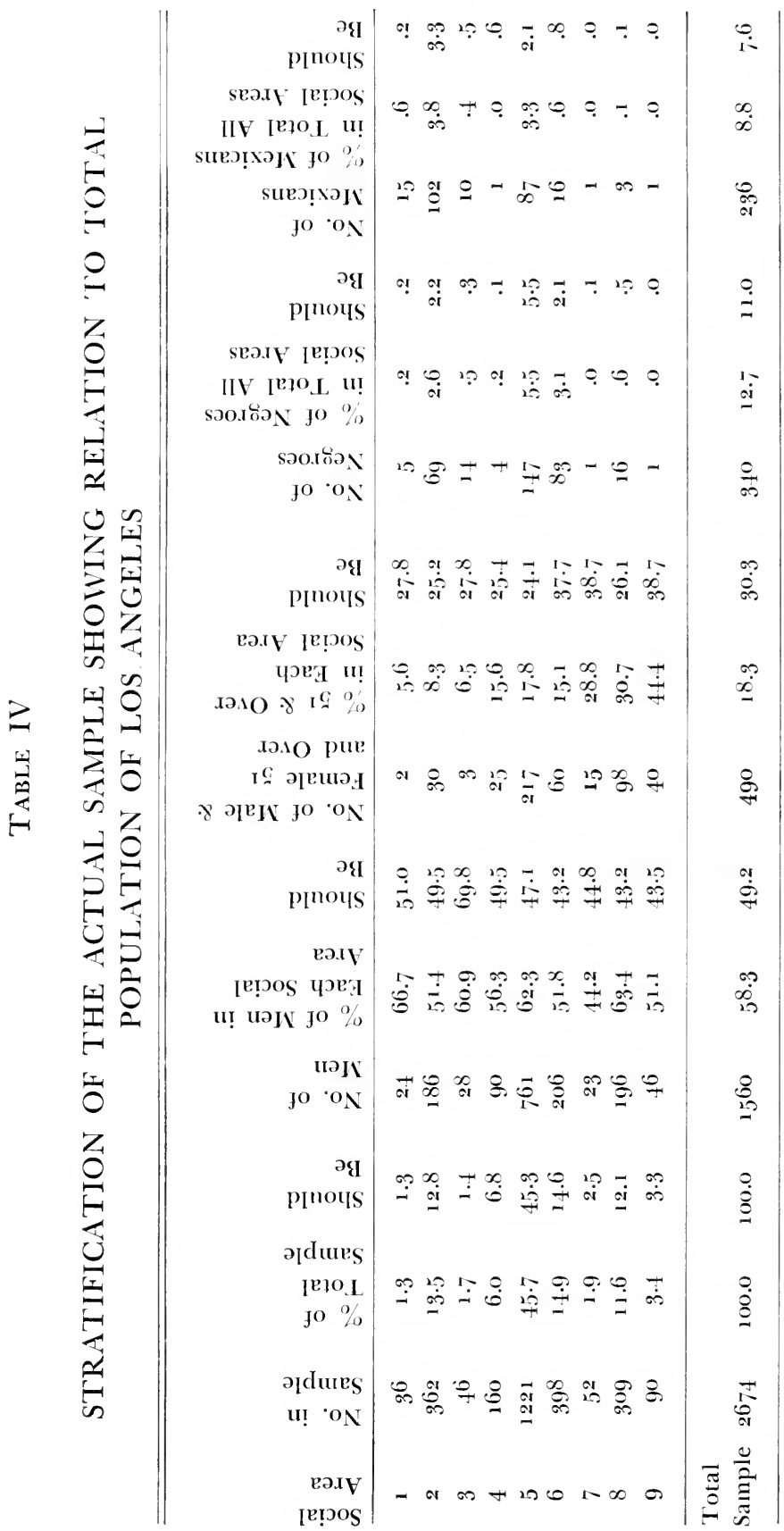




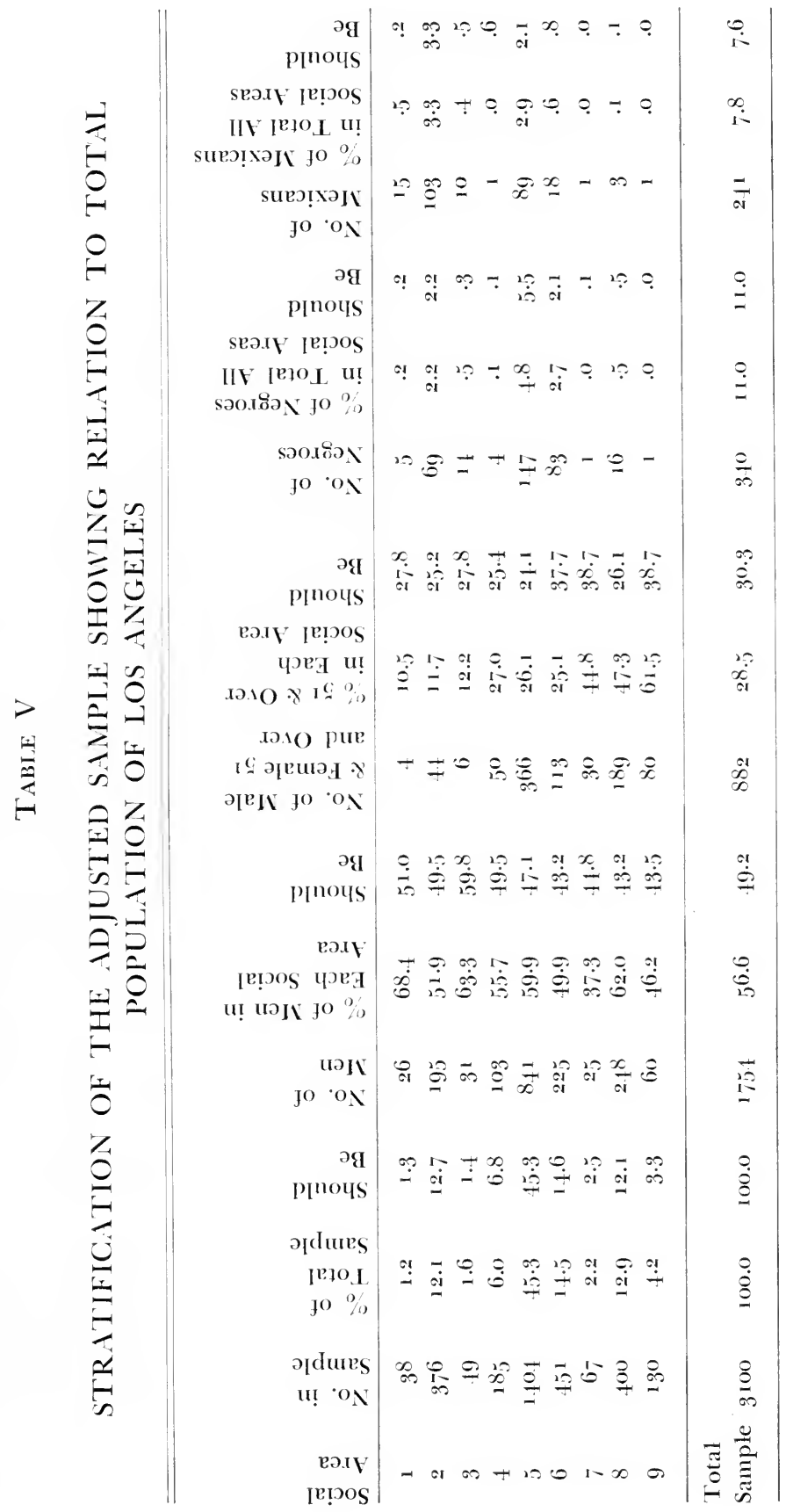


population of Los Angeles. The distribution of the 2674 cases in the actual sample is indicated in Table IV. This distribution corresponds very closely to that of the entire city as regards social area, sex, and race. However, as not enough older people were included, the sample was adjusted (as indicated in Table V) by duplicating punched cards for some of the older respondents. Throughout the balance of this report, whenever reference is made to the sample, it will be the adjusted sample of 3100 cases.

\section{VALIDATION OF QUESTIONS}

Parratt's Contribution: The statements in the multiple-choice section of the questionnaire (Figure 8) were taken largely from those developed by Spencer 1). Parratt. ${ }^{8}$ The responses of 97 citizens to seven questions concerning their opinions of certain police forces were analyzed to determine common patterns. Summary statements were prepared of the most frequently occurring responses. Of these, $34^{2}$ were retained and placed in order in 11 piles or intervals so as to permit relative evaluation of each statement as an aid or hindrance to police effectiveness.

Auditing the Scale: This auditing, or testing, of the scale was

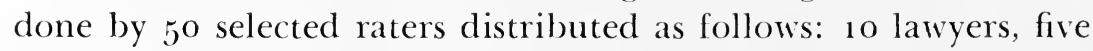
public administrators not involved in police work, five judges, 10 professional men and women, eight professors and graduate students, 10 prisoners in a county jail, a chief of police, a sheriff and an ex-sheriff, an assistant warden, and a jail keeper in a state penitentiary. The ambiguity index of each statement was computed, and those having an ambiguity index of more than 3.9 scale units were eliminated as lacking descriptive sharpness. From these statements, 126 were selected so as to provide contrasting statements insofar as possible in every classification or characteristic described. This scale included an approximately equal number of statements evaluated as contributing to or hindering the effectiveness of police functioning. From these 126 statements, there was selected, for each facet of police activity to be covered in the study, a statement with a very high index of effectiveness, and one with a very

\footnotetext{
${ }^{8}$ Parratt, Spencer D.: “A Scale to Measure Effectiveness of Police Functioning." J. Crim. Law and Criminol., 28:739-56, Jan.-Feb., $193^{8}$.
} 
GROUP NO

LOS ANGELES POLICE PUBLIC RELATIONS SURVEY

Dear Los Angeles Citized

No Pollce Department can be better than the quallty of 1 ts service to the Public. In order for your pollcenen to render the best possible service to you, they nus koov wat you think of their gualificetions, actions, and techniques; in order to iaprove thelr perforase in the puture, it is necessary that they know which of these you approve and which you do not. This nurvey has been designed so that you can tell the these things. Wth your identity reasing unaova.

To sasist us in this ourvey. we vould like to kno sev thiags about you which you can supply in the spaces indicated below.

Your tiae and effort 1 s sincerely apprecisted. Te know that you will be repaid through lmproved police service. Kindly furnisb all information requested a accurately a posable.

Age 1a years (1) $\mathrm{Male}$

Nationality: (1) American Negro

(3) Awerlcan Span18h

(2) Awerican Mexican

other: (Specify)

Marital Status
(1) single

(3) Dirorced

(2) Married

(4) $\mathbf{1}$ dowed

Rasidence: Pontal Zone or neareat crosa streets

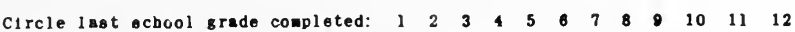

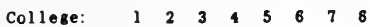

Length of residence in Lon Angolos: Yeara Montho

Occupation (Specify exactly)

If warted, occupation of hasband or wife

Below are listed toplcs dealing with various phases of police activity. Onder each topic appear four statements representing various degrees or etsndarda of police perforance. Kindly place an ' $X$ ' before the one statenent in esch group that represents oot nesrly your persons 1 opinion of Los angeles Policemen. Be sure and mark one, and only one, in each group of four. Thank you.

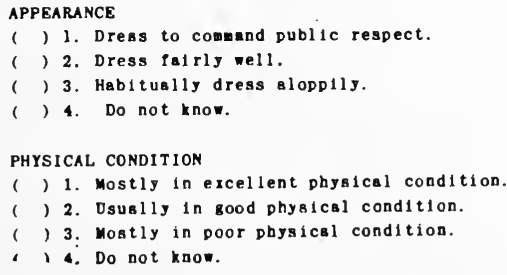

Figure 8. Questionnaire Used in Survey 


\section{EDUCATION}

( ) 1. Usually men of high school education or bigher.

( ) 2. Mostly men baving at least elementary school education.

( ) 3. Usually wen of little or no education.

( ) 4. Do not know.

\section{HONESTY}

( ) 1. Mostly aen of unquestionable honesty.

( ) 2. Usually men tho are falrly honest.

( ) 3. Mostly wen who are dishonest.

() 4. Do not know.

\section{COURTESY}

( ) 1. Habltually courteous in dealing $w$ th public.

( ) 2. Sometimes discourteous in dealing with the public.

() 3. Very discourteous in dealing with the public.

( ) 4. Do not know.

PROFESSIONUL INTEREST

( ) 1. Have bigb profesalonal interest in work.

( ) 2. Have moderate profesalonal interest in work.

( ) 3. Have only slight professional interest in work.

( ) 4. Do not know.

\section{TRAINING}

() 1. Highly trained in modern pollce nethods.

( ) 2. Fairly well trained.

( ) 3. Mostly poorly trained.

( ) 4. Do not know.

\section{BASIS OF SELECTION}

( ) 1. Members selected for personal werit and ability.

( ) 2. Members usually selected for peraonal merit and abllity.

( ) 3. Mewbers seldom selected for personal merit and ability.

() 4. Do not know.

DEPARTMENTAL DISCIPLINE

( ) 1. Operate under excellent discipline.

( ) 2. Operate under falrly good discipline.

( ) 3. Operate under poor discipline.

() 4. Do not know.

EQUIPMENT AND PACILITIES

() 1. Make use of all avallable modern Dolice equipaent.

( ) 2. Use some modern equipaent.

( ) 3. Do not understand the use of modern equipant.

() 4. Do not know.

INFLUENCE OF POLITICS

( ) 1. Apprebend criminals indiscriminately without regard for pressure brought by influential persons.

() 2. Occasionally show favoritisa to politicians.

( ) 3. Lose jobs by refuaing to obey orders of political bosses.

( ) 4. Do not know.

CRIME PREVENTION

() 1. Make consistent effort to educete public in how best to protect property.

( ) 2. occasionally give information to the public on how to protect property.

( ) 3. Seldom try to educate the public in means of protecting property.

() 4. Do not know.

Figure 8. Questionnaire Usfo in Survey

(Continued) 
JUVENILE DELINQUENCY

( ) 1. Uaully watcbel to prevent fureolle delingueocy.

( ) 2. Occasionally put fortb sone effort to prevent juvenile delinquency.

( ) 3. Indifferent concerolng juvenile dellaquency.

( ) 4. Do not know.

\section{INPLUENCE OP PRESS}

( ) 1. Operate independeotly frow newspaper publicity.

( ) 2. Pay particular atteotion to those criaes reported in the nevspapers.

( ) 3. Make serious effort to suppress crime only when newpapers complain.

() 4. Do not knov.

\section{INVBSTIGATION AND APPREHENSION}

( ) 1. Uaually aporebeod criainsla in difficult cases.

( ) 2. Have oderate mount of success in difficult cases.

( ) 3. Rarely get their wa in difficult cases.

() 4. Do not knov.

\section{TREATMENT OP SUSPBCTS}

( ) 1. Respect constitutional rights of suspocted crininals.

( ) 2. Use watever desree of force found convenlent.

( ) 3. Often consciencelese and brutal in performing duties.

( ) 4. Do not knov.

BOYS AND GIRLS

( ) 1. Liked by boys and al rls.

( ) 2. Boys and girls are indifferent.

() 3. Peared by boys ead sirls.

( ) 4. Do not knov.

\section{MINORITY GROUPS}

( ) 1. Usually falr id dealing with wority groups.

( ) 2. Sometimes unfriedily lo deslíg with minority groups.

() 3. Definitely prejudiced against inority groups.

( 4. Do not koov.

PROTECTION OP INNOCBNT

( ) 1. Careful not to arrest innocent peraons.

( ) 2. Occsaionally arrest innocent persons.

( ) 3. Indiffereat whether persons arrested are innocent or not.

() 4. Do not know.

\section{SUPERVISION}

( ) 1. Directed by blghly competent and efficient supervisors.

( ) 2. Supervisors are fairly competent and efficient.

( ) 3. Supervisors are inefficient and not qualified.

( ) 4. Do not know.

\section{TOP ADMINISTRATION}

() 1. Administrators or executives are very competent and well trained.

( ) 2. Adainistrators or executives are of average ability and competence.

( ) 3. Administrators or executives are incompetent and untrained.

( ) 4. Do not know.

\section{OVERALL EVALUATION}

( ) 1, One of the very best Police Departments in the country.

( ) 2. About on an average with other large Police Departaents.

( ) 3. Definitely below standard in comparison with other large Police Departwents.

() 4. Do not know.

Figure 8. Questionnaire Used in Survey

$$
\text { (Continued) }
$$


Most of your contacta with the Los Anceles Police Departaent bave been, and will continue to be, through lodividual Police officers. The balance of this survey ia designed to let you tell thea exactly wich of their actions, attitudes, etc. you like and which you dislike. You will be given several blue slipa and several pink slips. Kindly place the number which appeara on the top of this fora on each slip in order to prevent their being alspleced.

On the blue slips, describe very briefly incidenta, contacts or observations involving Los Angeles Pollceaed bicb you have perbonally experienced and of which you approved. Be aure to state exactly wat attitude, action, etc. you liked.

On the pink slips describe briefly incidents or contacts with Los Angeles Police officers which you have peraonally experiebced and of which you disspproved.

Place only one incldent or experience on each slid, but prepere as any slips as you recall incldents or as tive persits.

Attach the completed and nubbered slips to this for 1 th the paper clip provided.

Thank you agaid for the tiae and effort you bave given to this survey.

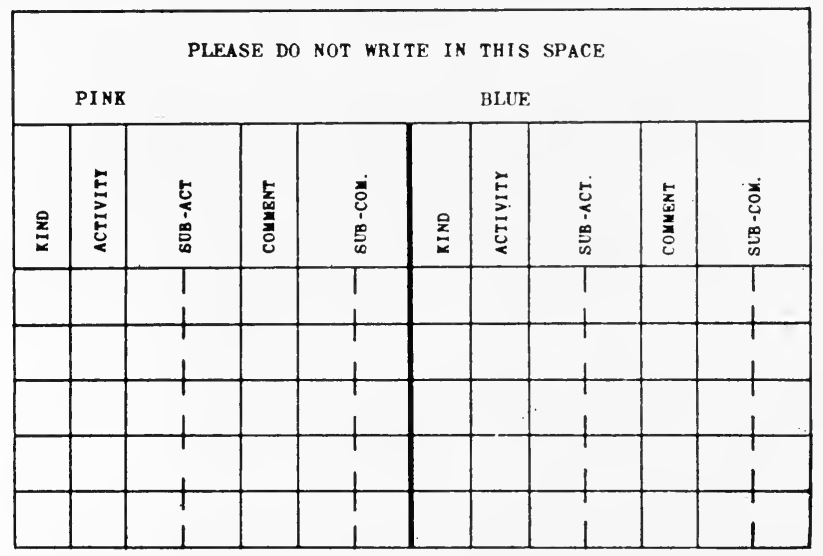

Figure 8. Questionnaire Used in Survey

(Continued)

low index of effectiveness. Where possible, one with a medium index of effectiveness was also selected; but where none was depicted on the scale, a statement representing a middleground was prepared. By index of effectiveness is meant the place on the 11point scale where the jury of $5^{\circ}$ persons had placed the particular statement in question. By this technique, it is believed that high contrasting statements with low indices of ambiguity were obtained.

\section{THE SURVEY FORM}

Cooperation of Respondents: Inasmuch as a survey of the nature of the present one is dependent almost entirely upon the 
cooperation of the respondents, it was pointed out in the questionnaire that in order for Los Angeles Policemen to render the best possible service to the public, they must know what the citizens think of their qualifications, actions, and techniques; that they know which of these are approved, and which are not. It was also indicated that this survey had been designed so that the policeman could be told these things with the respondent's identity remaining unknown.

Biographical Data: In order to be able to determine how different classes and groups of people responded to the questionnaire, the following personal or biographical data was solicited: age, sex, nationality, marital status, education, location of residence, length of residence in Los Angeles, and occupation.

Multiple-Choice Questions: Following the biographical information in the questionnaire appeared four statements concerning each of 22 topics dealing with various phases of police activity. These topics were: Appearance, Physical Condition, Education, Honesty, Courtesy, Professional Interest, Basis of Selection, Departmental Discipline, Equipment and Facilities, Influence of Politics, Crime Prevention, Juvenile Delinquency, Influence of the Press, Investigation and Apprehension, Treatment of Suspects, Boys and Girls, Minority Groups, Protection of Innocent, Supervision, Top Administration, and Overall Evaluation.

Under each topic appeared four statements representing three degrees or standards of police performance, together with a "Do Not Know" category. Respondents were asked to place an " $\mathrm{X}$ " before the one statement in each group that represented their personal opinion of Los Angeles Policemen. They were cautioned to mark one-and only one-in each group of four.

Free-Answer Responses: The final section of the questionnaire solicited free-answer responses. In connection with these, it was indicated that most of the respondent's contacts with the Los Angeles Police Department had been-and would continue to bethrough individual police officers; also, that an opportunity was now being presented for the respondent to tell the policeman exactly which of his actions, attitudes, etc., were liked, and which were disliked. Again, the respondent's anonymity was stressed. 
Lined half-sheets of paper, both blue and pink, were furnished with the questionnaires. Respondents were instructed-both in writing and, later, orally by the enumerator-to place the number which appeared on the questionnaire on the top of the slips in the space provided in order to prevent their being misplaced. The respondents were asked to report very briefly on the blue slips incidents, contacts, and observations involving Los Angeles Policemen which they had personally experienced, and of which they approved. On the pink slips, they were asked to report incidents or contacts of which they disapproved. They were instructed to place only one incident or experience on each slip; but were requested to prepare as many slips as incidents were recalled, or as time permitted, and to attach the completed and numbered slips to the questionnaire form with the paper clip provided.

\section{CONTACTING RESPONDENTS}

Mall Contacts: Upon considering available methods for contacting respondents, use of the mails was discarded because of the low rate of return to be expected, the cost involved, and the selectivity or bias which results from this technique. Mailed questionnaires are apt to be answered most readily by the better educated and more favorably inclined. ${ }^{9}$

Group Contacts: A method was conceived of contacting respondents in groups where they could be met face-to-face, and their cooperation urged. In order to have available a representative sampling, it was decided to contact groups containing a great variety of ages, economic levels, political philosophies, educations, and nationalities.

Cooperation of the Los Angeles Police Departalent: The cooperation of the Los Angeles Police Department, which is vitally interested in the results of this survey, was solicited, and arrangements made for members of the Public Information Division to act as enumerators. In this way, it was possible to obtain a much more extensive coverage than would have otherwise been possible.

Contacts with respondent groups were made through the Los

'Parten, Mildred: Surveys, Polls, and Samples. New York, Harper and Brothers, 195 o, p. 391 . 
Angeles Police Public Information Division, Traffic Education Unit, Geographical Division Commanders, Juvenile Officers, and through schools, colleges, and other organizations. Very important contacts, because of the normal difficulty of getting to them, were made with many union organizations-the American Federation of Labor, the Congress of Industrial Organizations, and othersthrough the Commander of the Metropolitan Division, whose work brings him into close and frequent association with these groups.

A face sheet was prepared and attached to each group of questionnaires giving the group number, the title of the organization, its address and telephone number, the name of the person in charge, and the name of the person through whom the contact was made; also, the number in the group, the date of the survey, and the name of the police representative or enumerator. Space was provided for comments by the enumerator.

The enumerators were given a short course of instruction, and a large, blown-up section of the questionnaire, containing the personal or biographical data, was prepared and used as a visual aid in explaining to the respondents the proper method of filling in the form.

\section{TALLYING RESPONDENTS' REPLIES}

All information on the questionnaire was coded and a punched card prepared for each respondent's replies (see Figure 9). A method of coding the free-answer responses was devised so that these replies could be placed on the punched card along with all other information by each respondent. The code consists of a seven-digit number. The first digit represents the kind of response; that is, blue or pink-favorable or unfavorable. The second digit describes the police activity involved; that is, traffic, motor patrol, detectives, etc. The third and fourth digits refer to the sub-activities; that is, writing traffic citations, giving information, patroling, etc. The fifth digit describes the subject of the comment; that is, whether it concerns attitudes, actions, words, etc. The sixth and seventh digits go into detail in telling just what the attitude was, or what exact action or words are referred to. At the top of each blue or pink slip was provided a series of seven boxes in which to record 


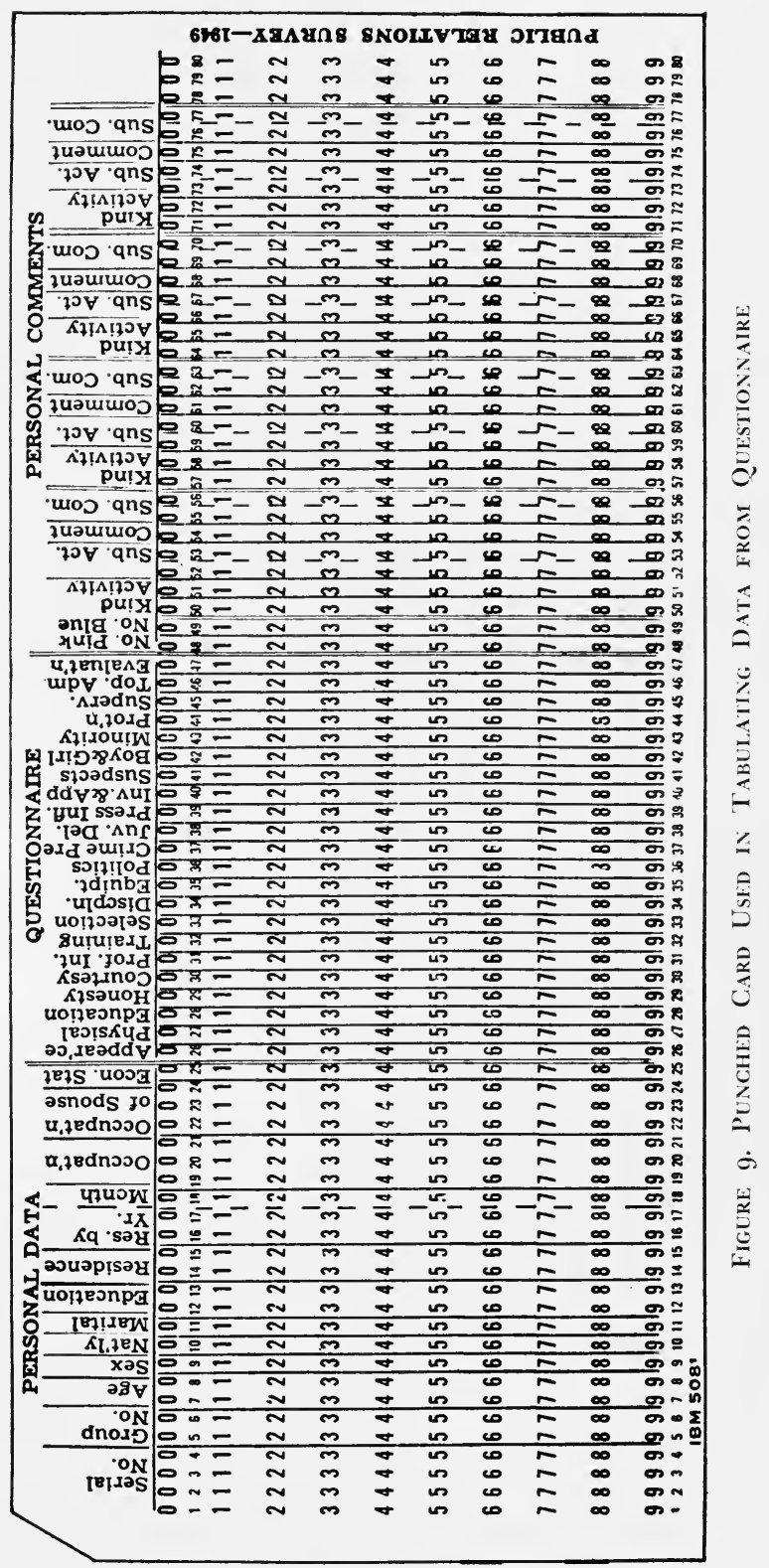


the appropriate code number. At the end of the questionnaire space was provided to note the number of blue and pink slips, and a space containing 10 series of seven boxes in order that the code number could be transferred from the colored slips to the questionnaire. This procedure allowed the key punch operator to work entirely from the questionnaire forms.

From the punched cards, tabulations were made and tables prepared showing the survey results by total respondents, age, sex, nationality, marital status, education, length of residence in Los Angeles, and occupation. The results of these tabulations are discussed in the following chapters. 


\section{Chapter IV}

\section{OVER-ALL PICTURE}

\section{MULTIPLE-CHOICE RESPONSES}

Favorable Impression: The general impression gained from a tabulation of the total sample is that the citizens of Los Angeles feel they have a very good police department. Although 47.6 per cent state that their department is about on an average with other large police departments, 27.6 per cent maintain that it is one of the very best in the Country, and only 10.4 per cent feel that it is below standard. Fourteen and four-tenths per cent admit that they do not know how the Los Angeles Police Department compares with other large departments.

Tangible Traits: The rating of the total sample is higher for those traits and modes of conduct which can be physically seen and measured; that is, Appearance, Physical Condition, Education, and Equipment and Facilities. The percentages in the top bracket for these traits are: $72.6,52.3,67.1$, and 55.9 , respectively; and the percentages in the lowest bracket are: $.5, .9,1.5$, and 2.4 , respectively.

Intangible Traits: The more intangible traits and qualities do not bring forth such enthusiastic responses; for example, only 29.2 per cent feel that Los Angeles Policemen are men of unquestionable honesty, while $5^{2.7}$ per cent admit that they are usually men who are fairly honest. The respondents seem to have a similar attitude toward police courtesy. Only 32.2 per cent think that policemen are habitually courteous in dealing with the public, while 55.4 per cent feel that they are sometimes discourteous. In other matters, the respondents are fairly evenly divided as between the top and middle brackets. Examples are: Professional Interest, 32.8 per cent and 39.6 per cent; Training, 43.0 per cent and 37.6 per cent; Basis of Selection, 33.7 per cent and 34.1 per cent; Departmental Discipline, 32.4 per cent and 39.7 per cent; Influence of Politics, 30.8 per cent and 38.5 per cent; Treatment of Suspects, 



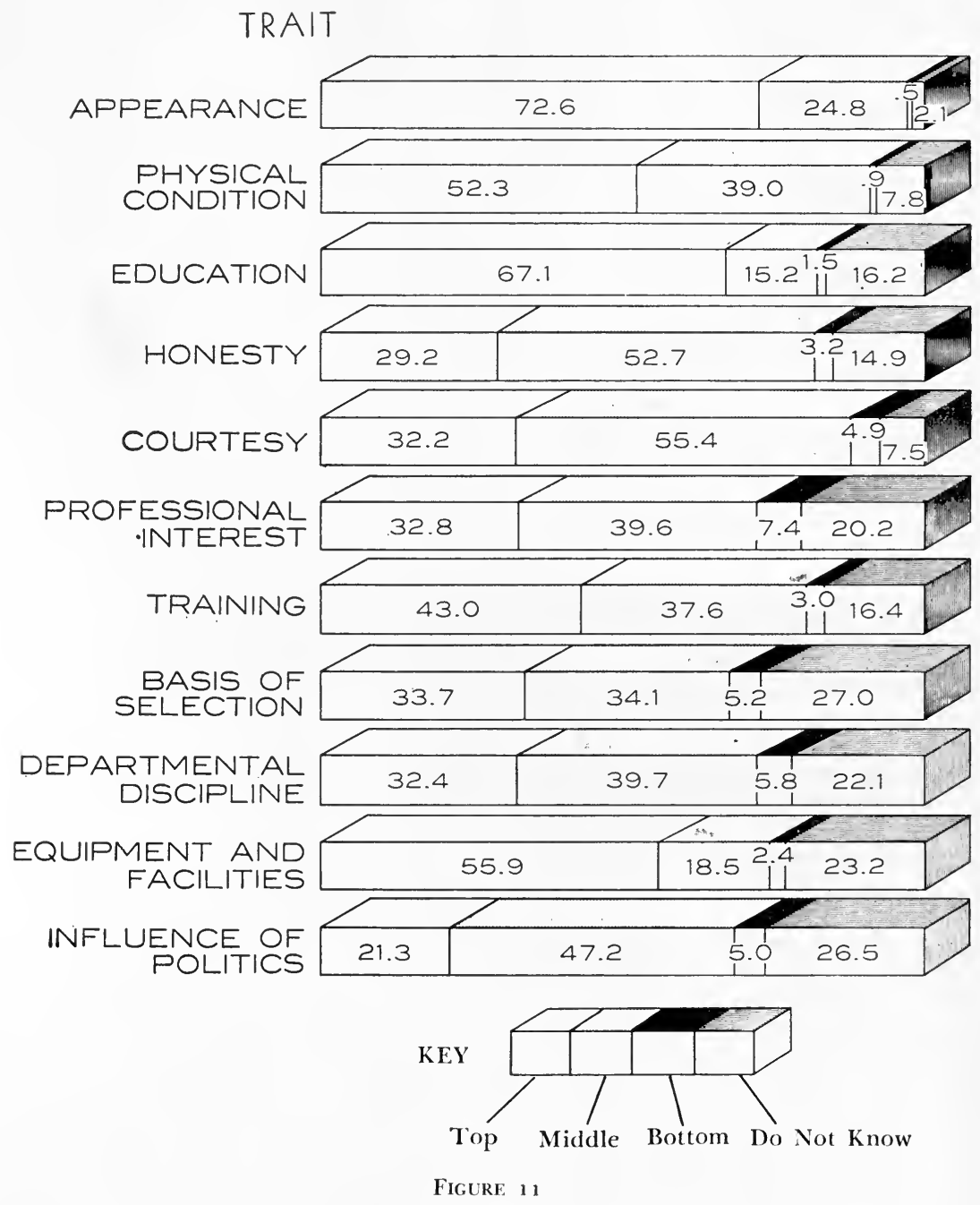

Distribution of total respondents' ratings of Los Angeles policemen by traits, showing percentage rating in top, middle, and bottom brackets, and percentage who do not know how to rate. 


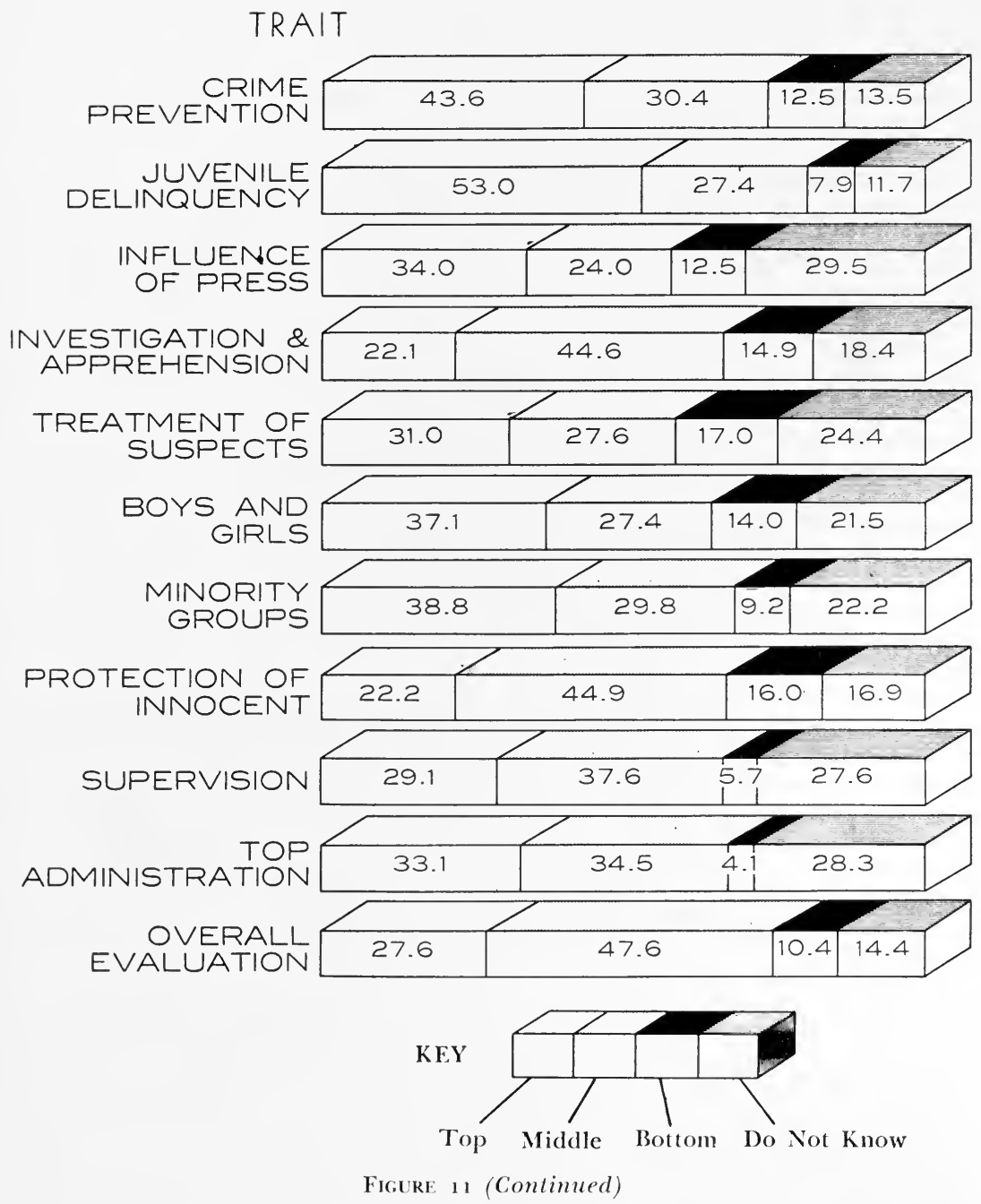

Distribution of total respondents' ratings of Los Angeles Policemen by traits, showing percentage rating in top, middle, and bottom brackets, and percentage who do not kuow how to rate. 
31.0 per cent and 27.6 per cent; Top Administration, 33.1 pe1 cent and 34.5 per cent, respectively.

Citizens' Lack of KNowledge: The validity of the survey is indicated by the low "Do Not Know" responses for those traits that are easily observed; for instance, Appearance, 2.1 per cent and Physical Condition, 7.8 per cent; and by the high "Do Not Know" responses for those traits which are not so readily observed by citizens; that is, Professional Interest, 20.2 per cent; Basis of Selection, 27.0 per cent; Departmental Discipline, 22.1 per cent; Influence of Politics, 26.5 per cent; Influence of the Press, 29.5 per cent; Treatment of Suspects, 24.4 per cent; Attitudes of Boys and Girls, 21.5 per cent; Attitudes Toward Minority Groups, 22.2 per cent; Supervision, 27.6 per cent; and Top Administration, 28.3 per cent.

About one fourth of all respondents admit that they do not know how to rate Los Angeles Policemen regarding the more intangible traits. This is a very high and significant percentage. It probably indicates a need for more thorough and concentrated effort to inform citizens how their police officers actually measure up to standards in these fields.

Over-all Evaluation: Figure 11 shows how the respondents rate Los Angeles Policemen as regards the various traits. It is interesting to note that a numerical average of respondents ratings for all 22 traits is more favorable than their over-all evaluation of Los Angeles Policemen. An average of all traits places 38.4 per cent in the top, 35.4 per cent in the middle, and only 7.5 per cent in the bottom brackets; whereas, the one item, Over-all Evaluation, places 27.6 per cent in the top, 47.6 per cent in the middle, and 10.4 per cent in the bottom brackets. There are probably many reasons for these differences-the principal one being that the various traits listed are not all of equal weight or value.

\section{FREE-ANSWER RESPONSES}

An examination of a tabulation of the free-answer, or written, responses brings to light many interesting facts. Of a total of 2,778 statements, 1,530-or 55.1 per cent-are unfavorable; and 1,248or 44.9 per cent-are favorable. The total responses thus average slightly less than one for each respondent-the unfavorable averag- 
ing one half, and the favorable slightly less than one half. Many respondents recorded several incidents; while others failed to report a single experience with the police. Where more than one statement was made on a single paper, it was broken down into its component parts and each expressed attitude given appropriate consideration.

\section{ACTIVITY AND SUB-ACTIVITY}

Traffic: Concerning the traffic field, 1205 written responses were recorded. Of these, 616-or $5^{1.1}$ per cent-are unfavorable; and 589 -or 48.9 per cent-are favorable. It should be noted, however, that the 616 adverse comments constitute only 40.3 per cent of the total unfavorable responses; while the 589 approving comments make up 47.2 per cent of the total favorable responses. Three hundred and six, or 49.7 per cent, of the unfavorable; and 175 , or 29.7 per cent, of the favorable comments regarding traffic concern the writing of citations. The directing of traffic, on the other hand, brings out 129 , or 21.9 per cent, of the approving, and only 71 , or 11.5 per cent, of the adverse statements.

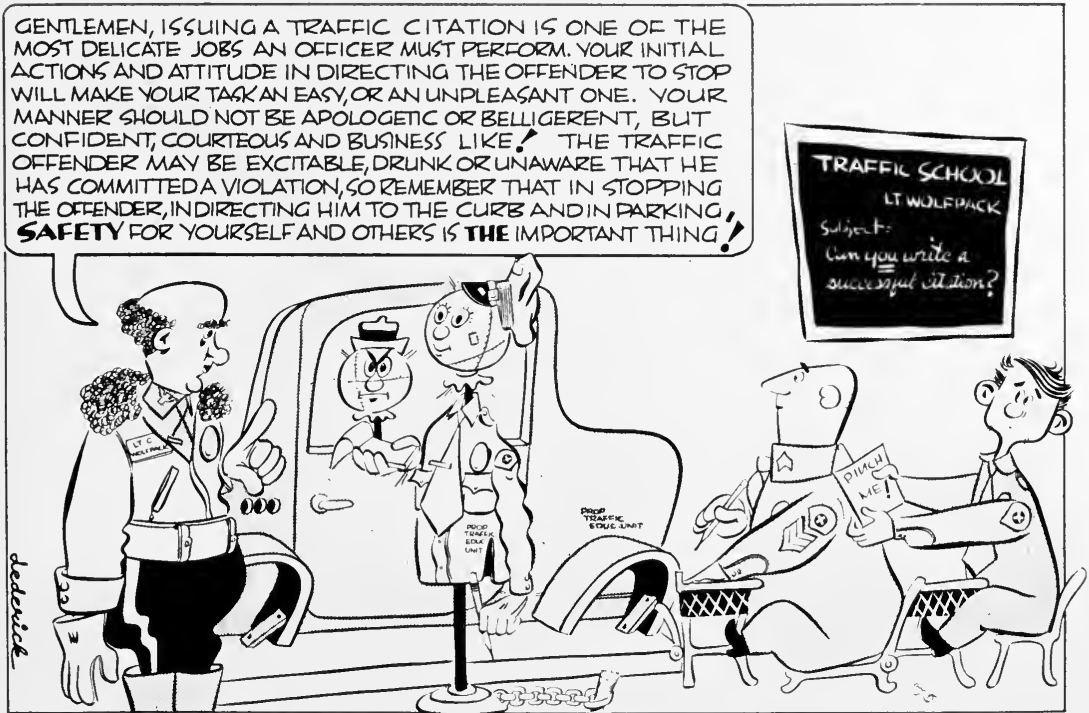

Figure 12. Issuing Traffic Citations 


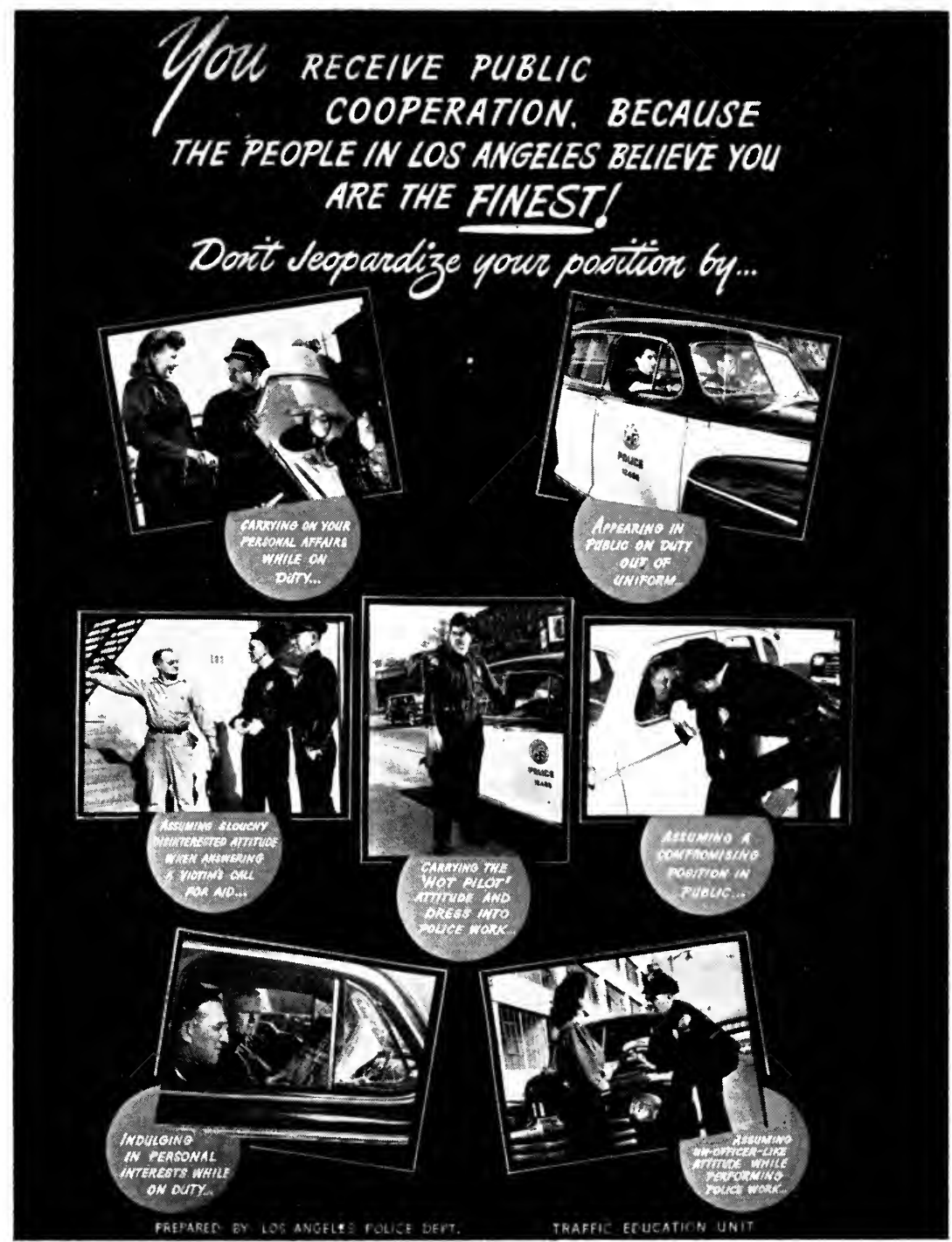

Figure 13. Actions and Attitudes to Avoid 
Uniformed Motor Patrol: Uniformed motor patrol other than traffic elicited less comments of both kinds than did traffic. This is understandable when one considers the relative frequency with which citizens are contacted by the two branches of police service. Of the $33^{6}$ comments in the field of uniformed motor patrol, 227 , or 67.6 per cent, are unfavorable; and 109 , or 32.4 per cent, are favorable. These unfavorable replies are only 14.8 per cent of all such responses, and the favorable ones only 8.7 per cent of all favorable responses. Of the 227 adverse comments regarding uniformed motor patrol other than traffic, 81-or 35.7 per cent - concern the answering of calls; 55 , or 24.2 per cent, deal with the making of field interrogations (shakedowns); and 44, or 19.4 per cent, with straight patrolling. Of the 109 satisfactory comments in this field, $5^{8}$, or 53.2 per cent, are concerned with the answering of calls; 21 , or 19.3 per cent, with patrolling; and 12, or 11.0 per cent, with giving assistance of various kinds.

Uniformed Foot PAtrol: Uniformed foot patrol induced 101 unfavorable and 30 favorable, or a total of 131 comments. Of the unfavorable, 36 , or 35.6 per cent, deal with field interrogations; 21 each, or 20.8 per cent, with making arrests and patrolling; and 16 , or 15.8 per cent, with the handling of drunks. Of the endorsing comments, 10 , or 33.3 per cent, mention patrolling; 7 , or 23.3 per cent, field interrogations; and 4 , or 13.3 per cent, the giving of information.

Detective Operations: Concerning detective operations, 134 comments were made. Of these, 72 , or 53.7 per cent, are unfavorable; and 62 , or 46.3 per cent, favorable. Of the antagonistic comments, 13 , or 18.1 per cent, each are made about the contacting of suspects, investigations at the scene of a crime, and investigations in general; and 11 , or 15.3 per cent, deal with the recovering of property. On the other hand, of the 62 approving comments about detective operations, 17, or 27.4 per cent, are about investigations at the scene of a crime; 14, or 22.6 per cent, about investigations in general; and 9, or 14.5 per cent, concern the recovering of property.

Juvenile Activities: Juvenile activities brought forth $115 \mathrm{com}$ ments, of which 65 , or $5^{6.5}$ per cent, are unfavorable; and $5^{0}$, or 43.5 per cent, favorable. Of the 65 adverse replies, 20 , or 30.8 per 


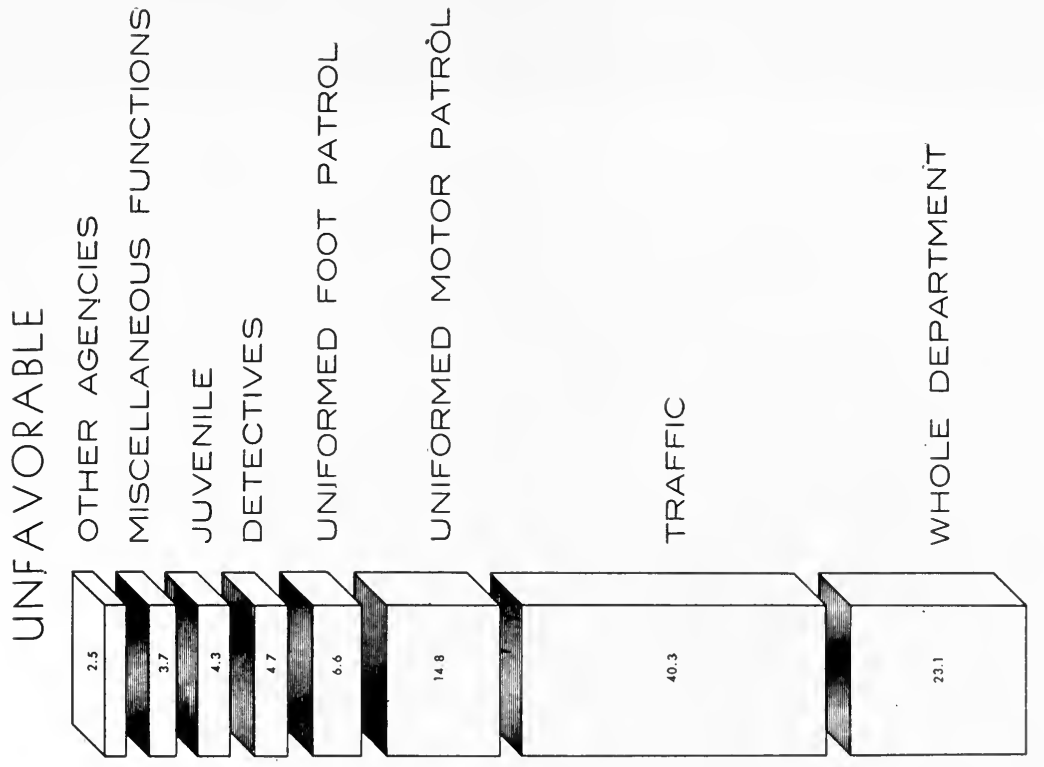

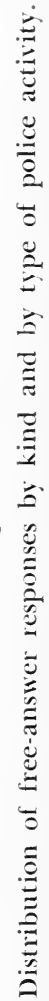

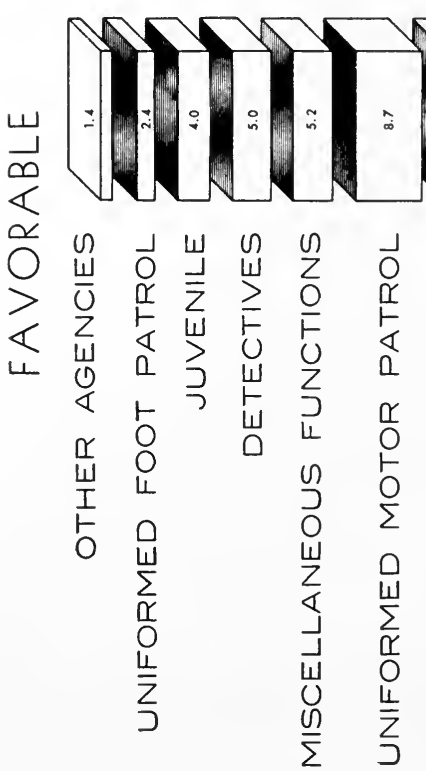

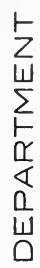

$\frac{1}{3}$ 


\section{POLICE ACTIVITY PER CENT}
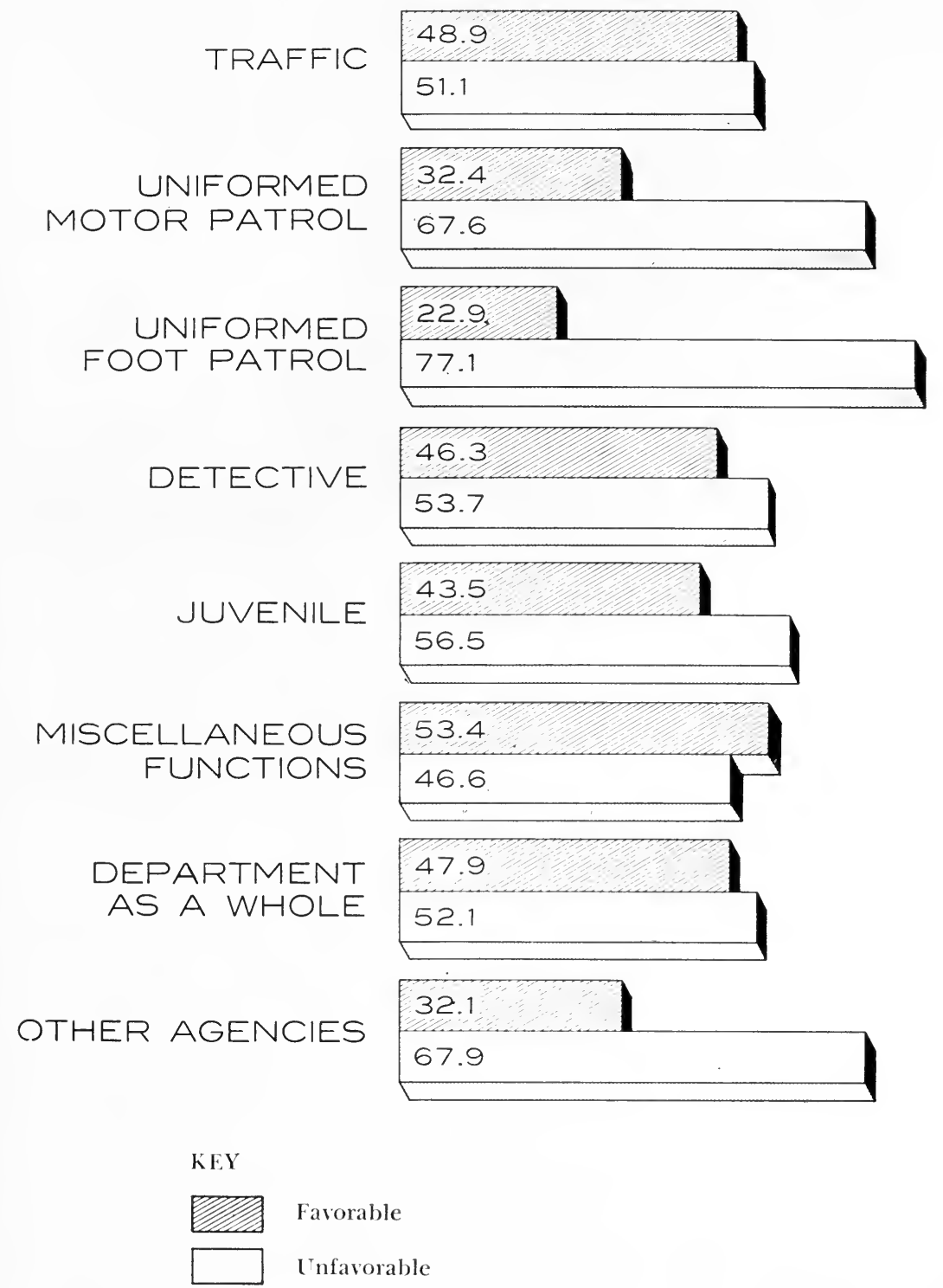

FigURE 15

Distribution of free-answer responses by type of police activity and by kind of response, i.e., favorable and unfavorable. 


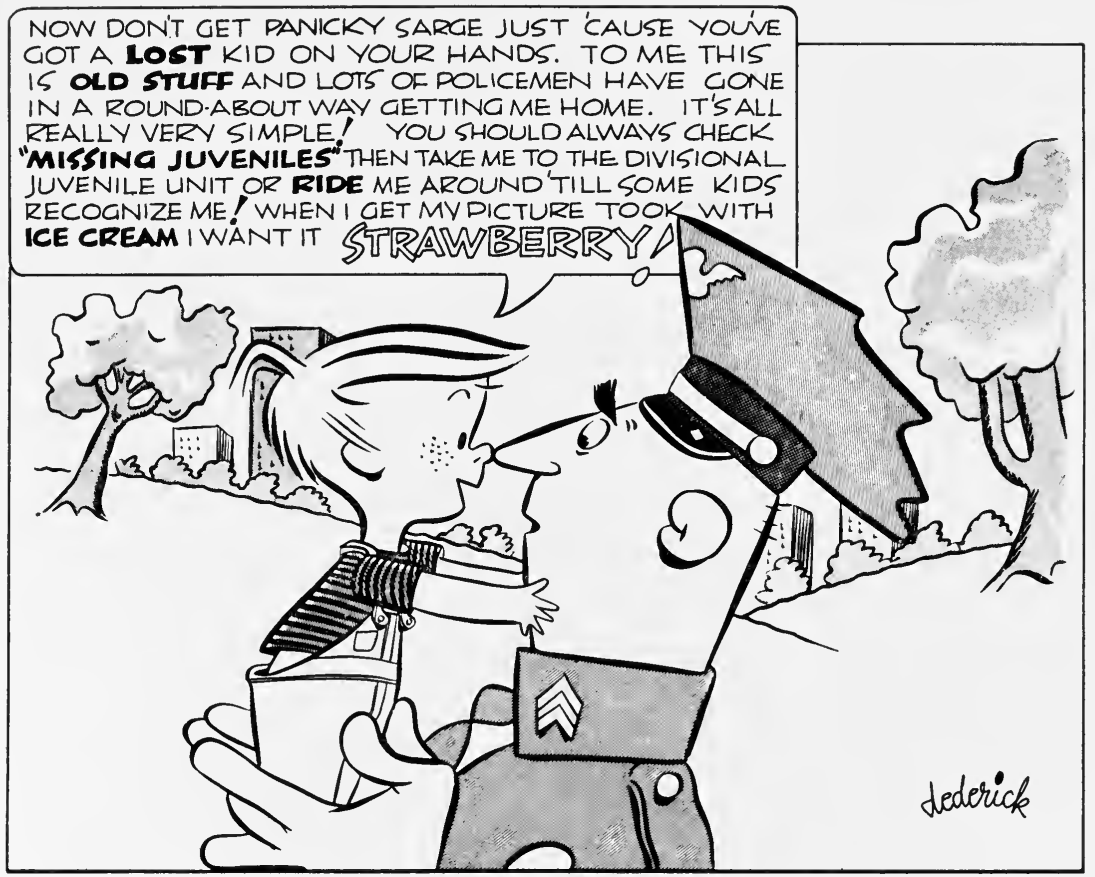

Figure 16A And 16B. A Lost Child

Contacts with children offer many opportunities for favorable public relations.

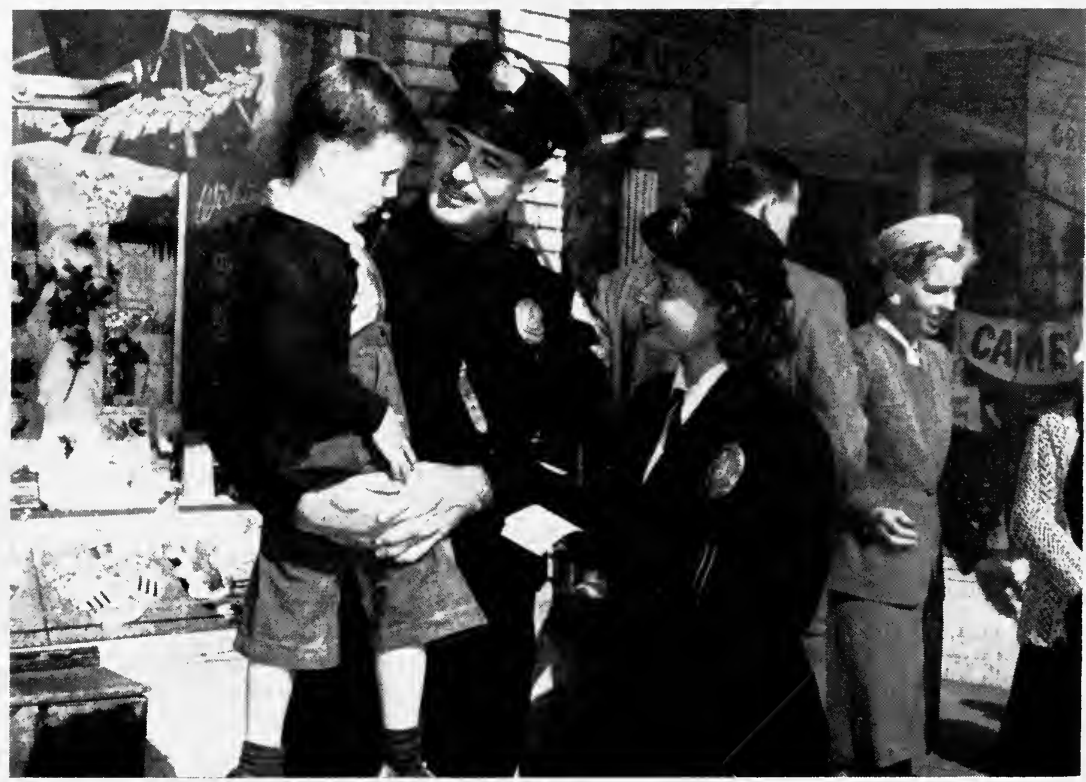


cent, concern the apprehending of juvenile offenders; 13, or 20.0 per cent, deal with the checking of exposed places (indecent shows, pool rooms, etc.); and 9, or 19.8 per cent, contacting suspects. Among the 50 approving comments concerning juverile activities, 21 , or 42.0 per cent, mention the curbing of juvenile delinquency; and 10 , or 20.0 per cent, the finding of lost children.

Miscellaneous Functions: Under a heading of Miscellaneous Functions, 57 unfavorable and 65 favorable replies, or a total of 122 comments, are recorded. This grouping contains 4.4 per cent of all voluntary statements. A majority of the comments- $53 \cdot 4$ per cent-are favorable. It should be observed that this is the only class of police activity about which more favorable than unfavorable comments were made. In the favorable category are 11 , or 16.9 per cent, dealing with public relations; 8 , or 12.3 per cent, about the Deputy Auxiluary Police Force; 7, or 10.8 per cent, concern giving

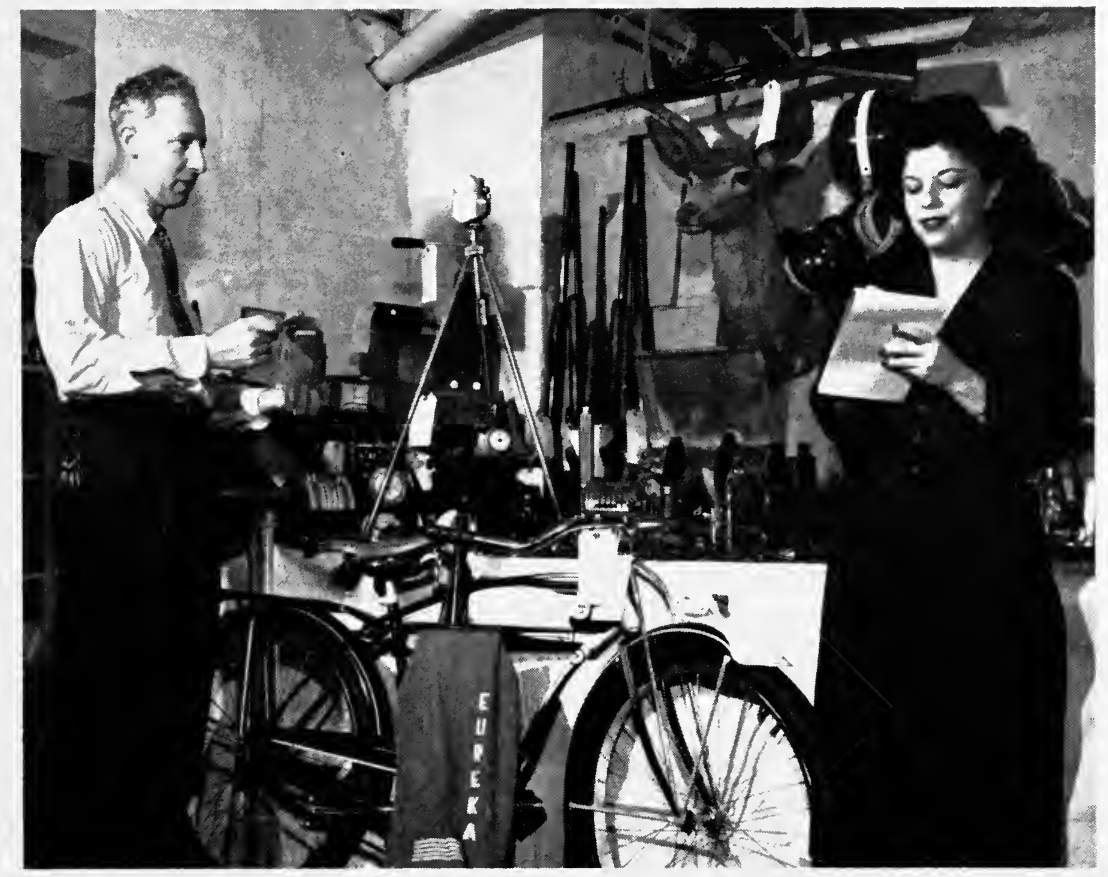

Figure 17. Ricovered Property

Efficient recovery of property and its return to rightful owners create confidence in the police on the part of the public. 
information over the counter or by correspondence; and 6 , or 9.2 per cent each, about giving testimony in court, handling crowds, and supervising civilian defense activities. Among the unfavorable comments are 14, or 24.6 per cent, dealing with the handling of vice situations; 11 , or 19.3 per cent, concerning custody of prisoners; 9, or 15.8 per cent, are about telephone conversations; and 8 , or 14.0 per cent, are about report taking.

Police Departifnt as a Whole: Dealing with the police department as a whole are 679 comments, of which 354 , or $5^{2.1}$ per cent, are unfavorable; and 325 , or 47.9 per cent, are favorable. Of the 354 unfavorable comments, 237 , or 66.9 per cent, are about general activities, as are also 297 , or 91.4 per cent, of the favorable comments. Thirty-one of the adverse statements, and 12 of the comments of endorsement, are concerned with administration.

Police Contacts and Public Relations: A study of the above facts would appear to indicate convincingly that public attitudes toward the police, or police public relations, are in direct proportion to the number of contacts between the police and the public;

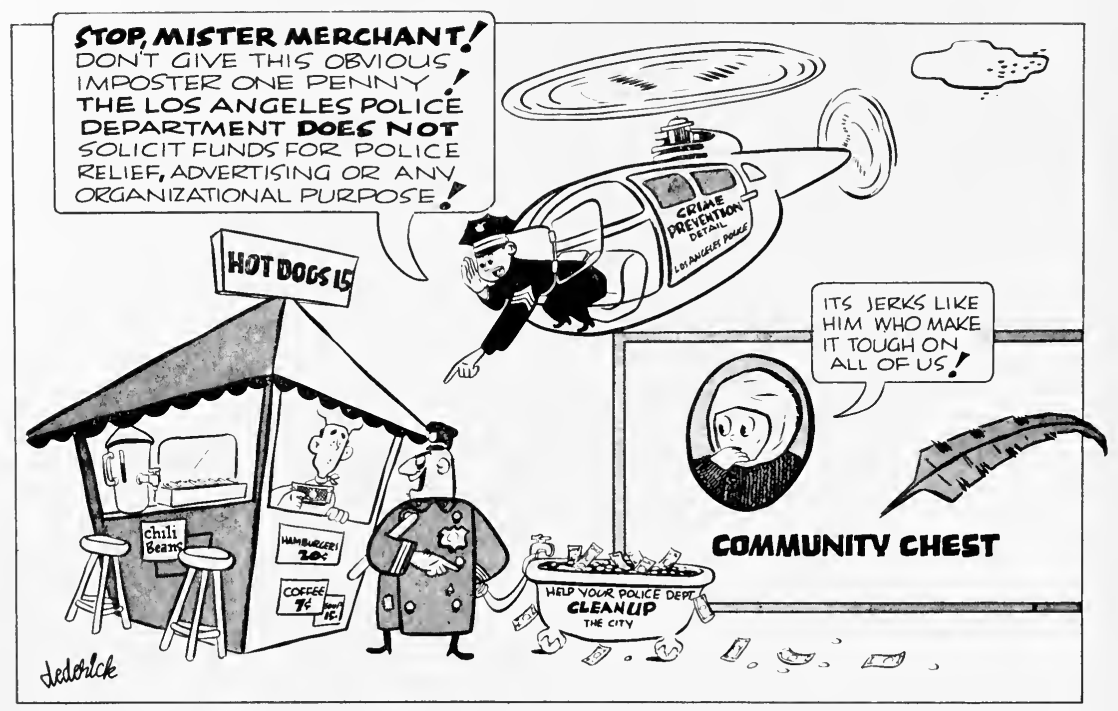

Figure 18. Solicitation by Polich

The public often resents solicitation of funds by the police. If absolutely necessary, one drive should be held at the same time each year. Rackets using police names or relationships should be constantly watched for and eliminated. 
and that whether these relations are good or bad depends upon whether the preponderance of contacts are favorable or unfavorable. This survey clearly shows, as indicated in Figures 14 and 15 that even in the field of traffic, where many adverse punitive contacts must, of necessity, be made, a preponderance of favorable attitudes can be developed and maintained. Uniformed foot patrol which, on the other hand, because of its vast possibilities for favorable contacts, could produce a great majority of desirable attitudes, does not necessarily do so. The controlling factors would appear to be the quality of selection, training, and supervision of policemen assigned to the various facets of police activity.

\section{COMMENT AND SUB-COMMENT}

Attitudes of Officers: Among the 2778 comments, 963, or 34.7 per cent, refer to the attitudes of police officers. Of these comments, 526 , or 54.6 per cent, are unfavorable; and 437 , or $45 \cdot 4$ per cent, are favorable. Among the most frequently mentioned adverse comments regarding the attitudes of Los Angeles Policemen are 110 , or 20.9 per cent, concerning discourtesy; 91, or 17.3 per cent, dealing with some form of prejudice; 85 , or 16.1 per cent,

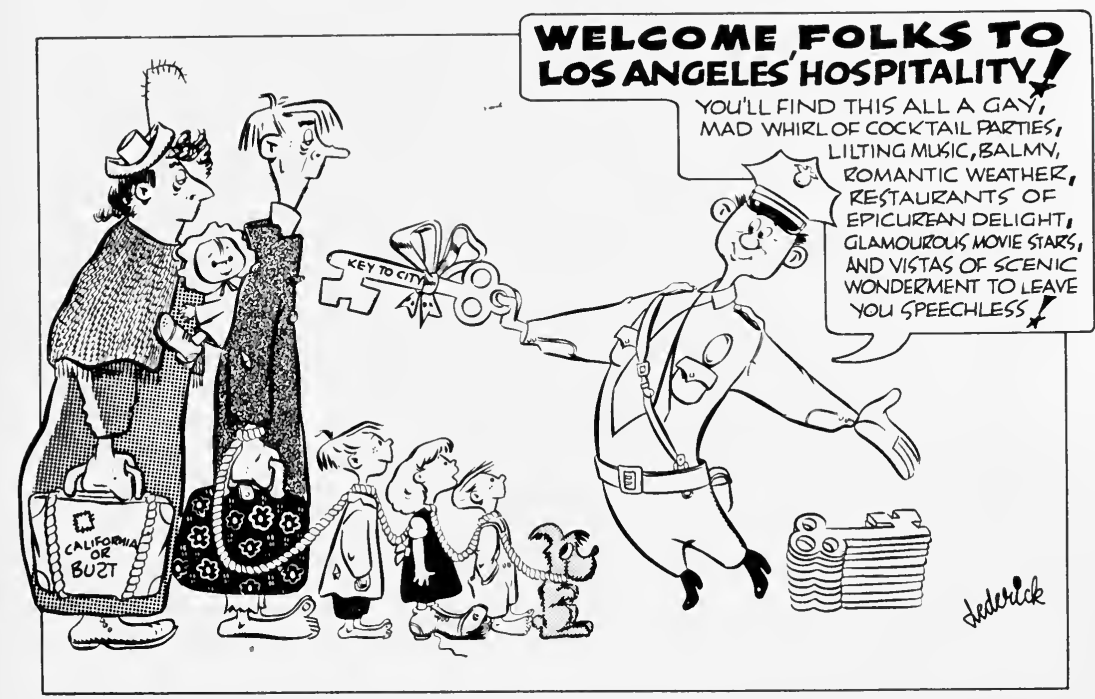

Figure 19. Tile Public Expects its Police to Be Courteous 


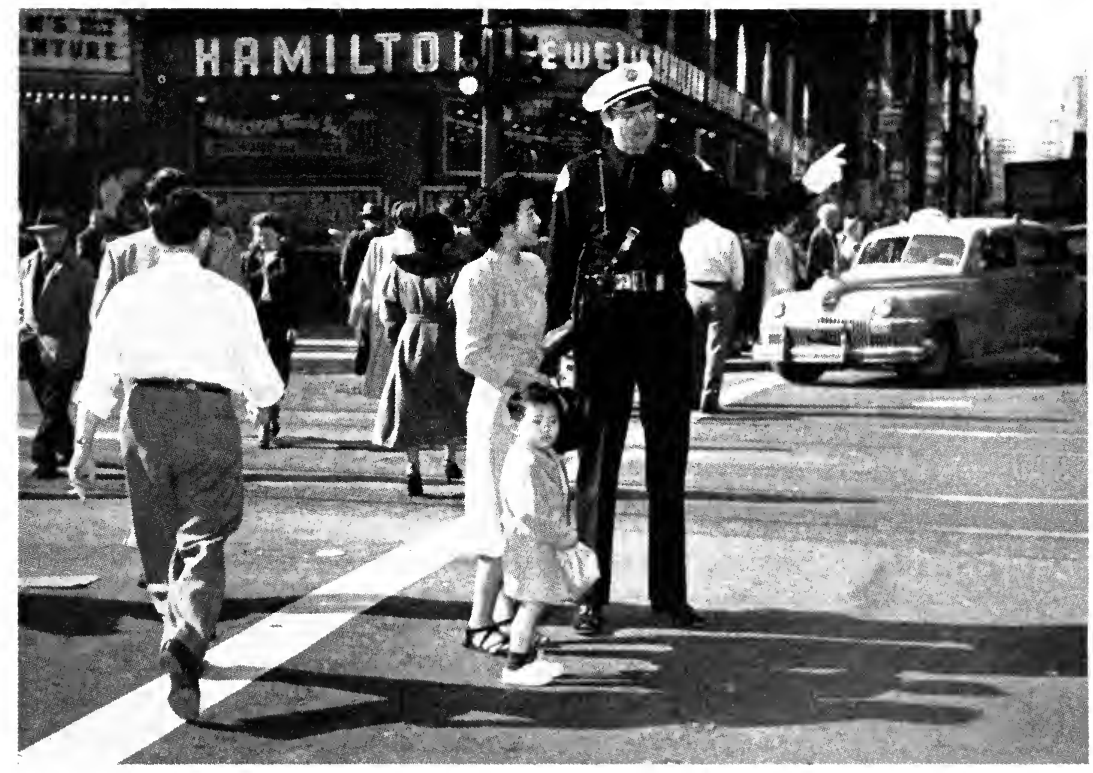

Figure 20A and 20B. Tile public Explets Its Police to Be Heipfil and Concerned

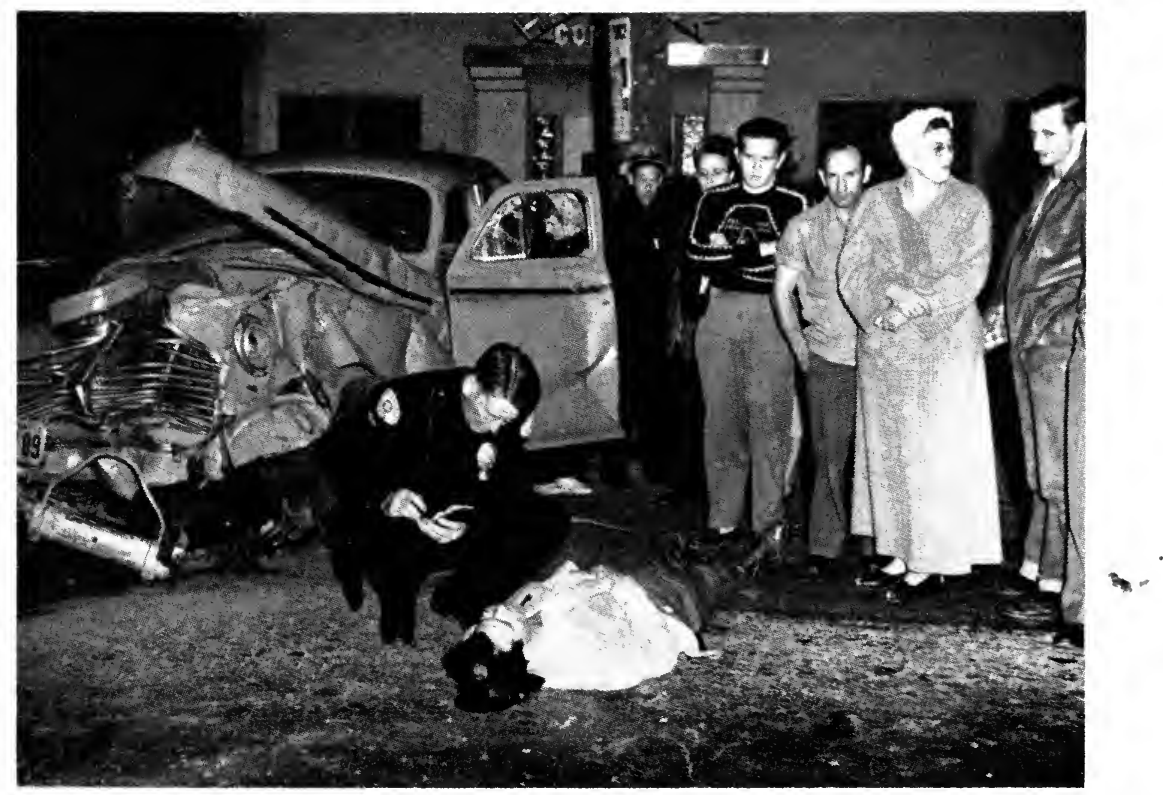


with over-bearing or superior attitudes; and 50, or 9.5 per cent, with their lack of cooperation, and indifference. Forty-one, or 7.8 per cent, of the unfavorable statement concerning attitudes are to the effect that the police have been sarcastic or belligerent.

The 437 favorable comments regarding attitudes comprise 35.0 per cent of all such comments. Among these are 257 , or $5^{8.8}$ per cent, dealing with courtesy; 59, or 13.5 per cent, concerning

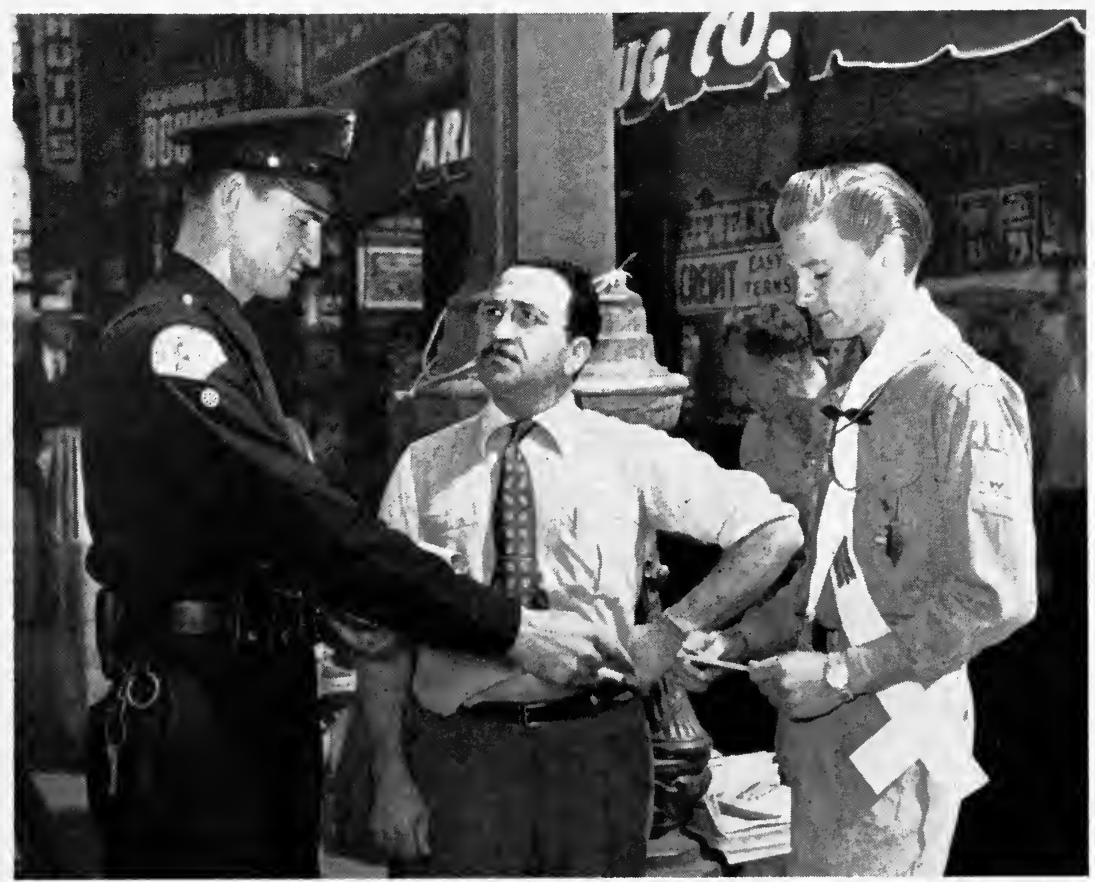

Figure 21. The Public Expects Its Police to Be Prepared

In the posed photograph, the officer has created a poor impression by borrowing a pencil in order to write a citation.

police cooperation; 46, or 10.5 per cent, regarding their sympathetic and concerned attitude; and 26 , or 5.9 per cent, dealing with their helpfulness.

Actions of Offickrs: The most frequently-occurring statements of respondents concern actions by policemen. Of all the 2778 comments, 1283 , or 46.2 per cent, deal with actions by Los Angeles Policemen. Of these, 839 , or 65.4 per cent, are unfavorable; and 444, or 34.6 per cent, are favorable. The most frequently- 


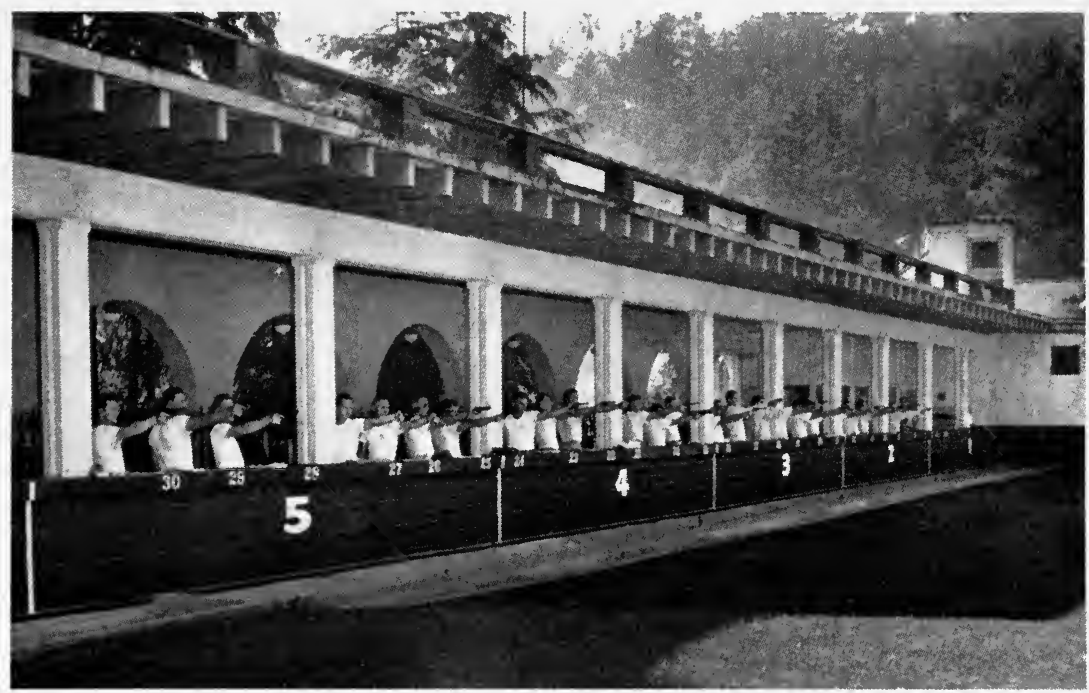

Figure 22. Practice Makes Perfect

Citizens want their policemen to be skillful and proficient. Above: Recruits practice at the Los Angeles Police Academy.

occurring adverse comments regarding police actions are: unjustified arrests or tickets, 127 , or 15.2 per cent; rough treatment, 85 , or 10.1 per cent; inconsistency of traffic enforcement, 82, or 9.8 per cent; unjustified questioning, 58 , or 6.9 per cent; incompetency, 51, or 6.1 per cent; laying speed traps, 48 , or 5.7 per cent; and "slow to answer calls," 31 , or 3.7 per cent.

The most frequently-occurring favorable comments by the respondents regarding police actions are: competency, 266, or 59.9 per cent; helpfulness, 64 , or 14.5 per cent; "no tickets given," 32, or 7.2 per cent; promptness, 28 , or 6.3 per cent; and assistance to persons, 26 , or 5.9 per cent.

Oтнer Comments: Skill and training brought out 392 comments, which is 14.1 per cent of all comments. Of these, 46 , or 11.7 per cent, are unfavorable; and 346 , or 88.3 per cent, favorable.

Strangely enough, personal appearance of Los Angeles Police Officers (which was rated so highly in the multiple-choice section) brought out only 23 statements, which is but .8 per cent of all comments. Of these, 8 , or 34.8 per cent, are unfavorable; and 15 , or 65.2 per cent, are favorable. 


\section{Chapter $V$ \\ BIOLOGICAL FACTORS}

\section{AGE GROUPS}

B

asis fOR SElection: Respondents' replies were broken down into age groups so as to obtain a picture of differences in attitudes toward the police by people of various ages. Those 17 and under were grouped together in order to sample the attitudes of high school students. The 18 to 24 age group contains most of the college students. For convenience, the other groups were selected in 1o-year spans; that is, 25 to 34,35 to 44,45 to 54 , and 55 and over. The distribution of the total sample among the selected age groups is very good. The number and per cent of respondents in each group is shown in Figure 23.

Older Citizens: The age group most favorably inclined toward the Los Angeles Police Department is definitely the 55 and over classification. This is shown by their over-all evaluation as well as by their selection among the alternatives for each of the other traits. Thirty-eight and one-tenth per cent of the senior citizens feel that they have one of the very best police departments in the Country; whereas, an average of only 27.6 per cent of all respondents agree with them. Only 3.7 per cent of the 55 and over group state that the Los Angeles Police Department is below standard in comparison with other large police departments; while an average of 10.4 per cent of all respondents feel this way.

Of the 55 and over group, 78.3 per cent believe that Los Angeles Police Officers dress to command public respect, as compared with 72.6 per cent for all respondents. As regards physical condition, 65.1 per cent of the older group indicate a belief that their policemen are mostly in excellent physical condition, as compared with 52.4 per cent of all respondents who share this view. Other traits for which the older group placed the Los Angeles Policemen in the top category more often than did all respondents are indicated at the top of the next page. 
Honesty

Courtesy

Professional Interest

Influence of Politics

Crime Prevention

Prevention of Juvenile Delinquency

Influence of the Press

Investigation and Apprehension

Treatment of Minority Groups

Protection of Innocent

Supervision

Top Administration

$\begin{array}{cc}\text { Fifty-five } & \text { All } \\ \text { and Over } & \text { Respondents } \\ 35.5 & 29.2 \\ 44.6 & 32.2 \\ 37.1 & 32.8 \\ 25.6 & 21.3 \\ 5^{0.1} & 43.6 \\ 5^{8.2} & 53.0 \\ 39.6 & 34.0 \\ 26.4 & 22.1 \\ 41.0 & 3^{8.8} \\ 26.4 & 22.2 \\ 32.7 & 29.1 \\ 39.8 & 33.1\end{array}$

The favorable attitudes of the older group are graphically illustrated by a comparison of their number who place Los Angeles Policemen in the bottom bracket for each trait, as compared with all respondents. Not a single person in the 55 and over age group feels that the officers habitually dress sloppily, or that they are in poor physical condition. Only $\mathbf{1 . 6}$ per cent of the "oldsters" feel that Los Angeles Policemen are mostly men who are dishonest; while 3.2 per cent, or twice as many of all respondents, have this uncomplimentary attitude.

The percentages for other traits for which the older group places the policemen in the lowest category less often than do all respondents are indicated below.

Courtesy
Professional Interest
Training
Basis of Selection
Discipline
Influence of Politics
Crime Prevention
Influence of Press
Treatment of Suspects
Attitudes of Boys and Girls
Treatment of Minority Groups
Protection of Innocent
Supervision
Top Administration

$\begin{array}{cc}\text { Fifty-five } & \text { All } \\ \text { and Over } & \text { Respondents } \\ 2.3 & 4 \cdot 9 \\ 1.3 & 7 \cdot 1 \\ 1.8 & 3.1 \\ 2.8 & 5.2 \\ 2.2 & 5.8 \\ 2.0 & 5.0 \\ 7.9 & 12.5 \\ 7.5 & 12.5 \\ 9.1 & 17.0 \\ 5.7 & 14.0 \\ 4.7 & 9.2 \\ 7.9 & 16.0 \\ 2.2 & 5.7 \\ 1.2 & 4.1\end{array}$




\section{AGE GROUPS PER CENT}

17 YEARS AND UNDER \begin{tabular}{|l|l|l|}
25.6 & 47.7 \\
& &
\end{tabular}
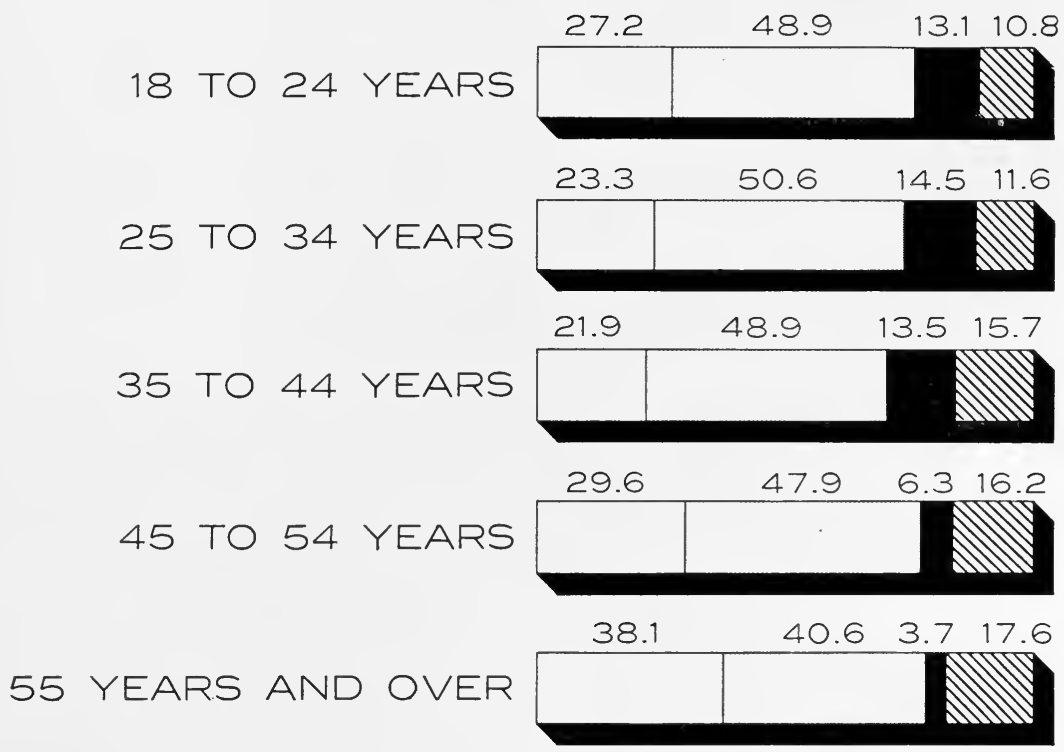

$\mathrm{KFY}$

One of the very

best Police Departments

in the country

About on an average

with other large

Police Departments

Definitely below standard

in comparison with other large Police Departments

Do not know

\section{Distribution of Sample}

Total No.

in Sample l'ercent

17 and under
18 to 24
25 to 34
35 to $4 t$
15 to 54
55 and over

$\begin{array}{rr}281 & 9.1 \\ 518 & 16.7 \\ 636 & 20.5 \\ 534 & 17.2 \\ 621 & 20.1 \\ 507 & 16.4 \\ --- & - \\ 3100 & 100.0\end{array}$

Fif;uRe 23

OVIR-All Evaluation by Agr of Rispondints.

Distribution of multiple-choice ratings of Los Angeles

Policemen by age of respondents. 


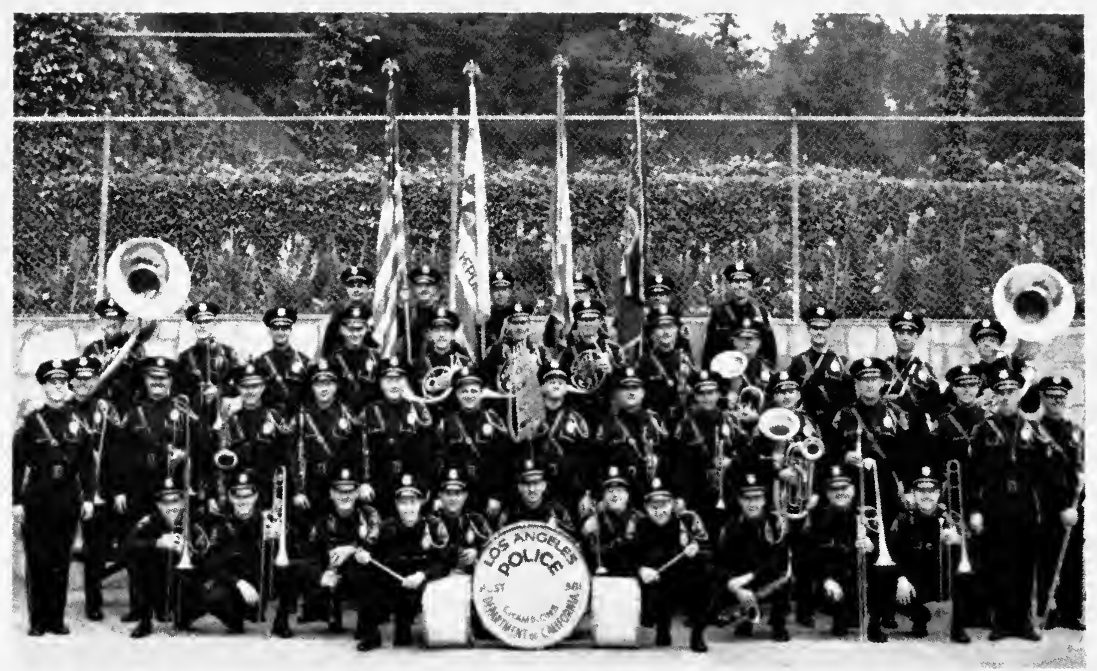

Figure 24. The Los Angeles Police Departuent Band

Many police departments sponsor bands, glee clubs, or other musical groups for purposes of public relations and internal morale.

Severest Critics: Three age groups vie with each other to be the most severe critics of the Los Angeles Police Department or, rather, to be the least enthusiastic concerning it. These are the 18 to 24,25 to 34 , and 35 to 44 year groups. Whereas, 27.6 per cent of all respondents cast their votes for the Los Angeles Police Department as being one of the very best police departments in the Country, only 27.2 per cent in the 18 to 24 age group, 23.3 per cent in the 25 to 34 age group, and 21.9 per cent in the 35 to 44 age bracket agree with this viewpoint; while 13.1 per cent in the 18 to 24 year bracket, 14.5 per cent in the 25 to 34 year bracket, and 13.5 per cent in the 35 to 44 year group, as compared with only 10.4 per cent of all respondents, feel that the Los Angeles Police Department is below standard in comparison with other large police departments.

The attitudes of these three age groups, as expressed in their over-all evaluations, are reinforced by their expressed attitudes toward most of the other listed traits. For example, an average of only 24.7 per cent in the three age groups feel that their policemen are mostly men of unquestionable honesty; whereas, an average of 


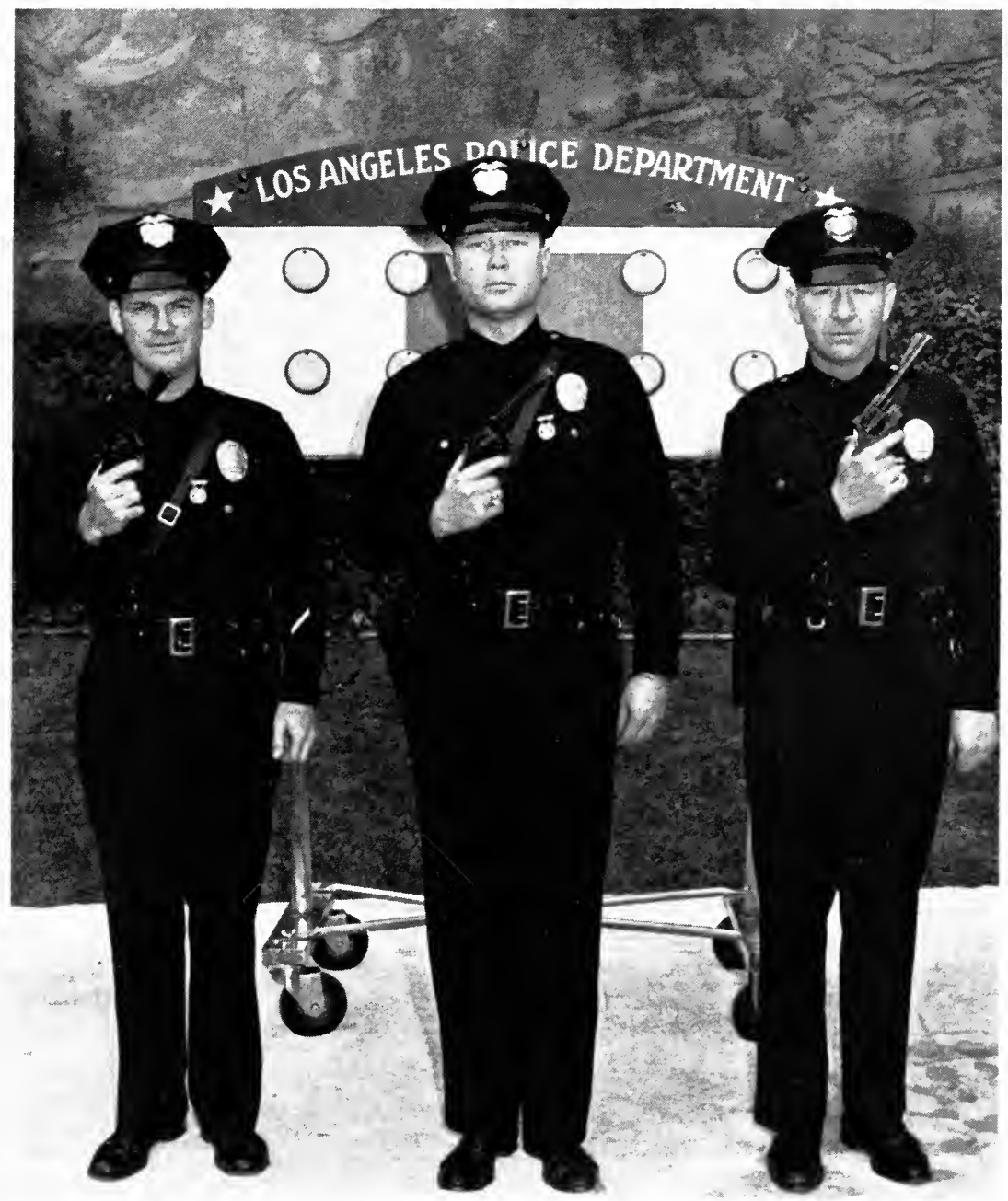

Figure 25. A Police Pistol leam

Police lepartments sponsor many athletic teams, drill teams, exhibition shooting teams, etc, all of which bring about favorable contacts with the pullic.

29.2 per cent of all respondents feel this way. An average of only 25.2 per cent of the same three groups expressed a belief that Los Angeles Policemen are habitually courteous in dealing with the public; whereas, 32.2 per cent of all respondents express this more complimentary view. 


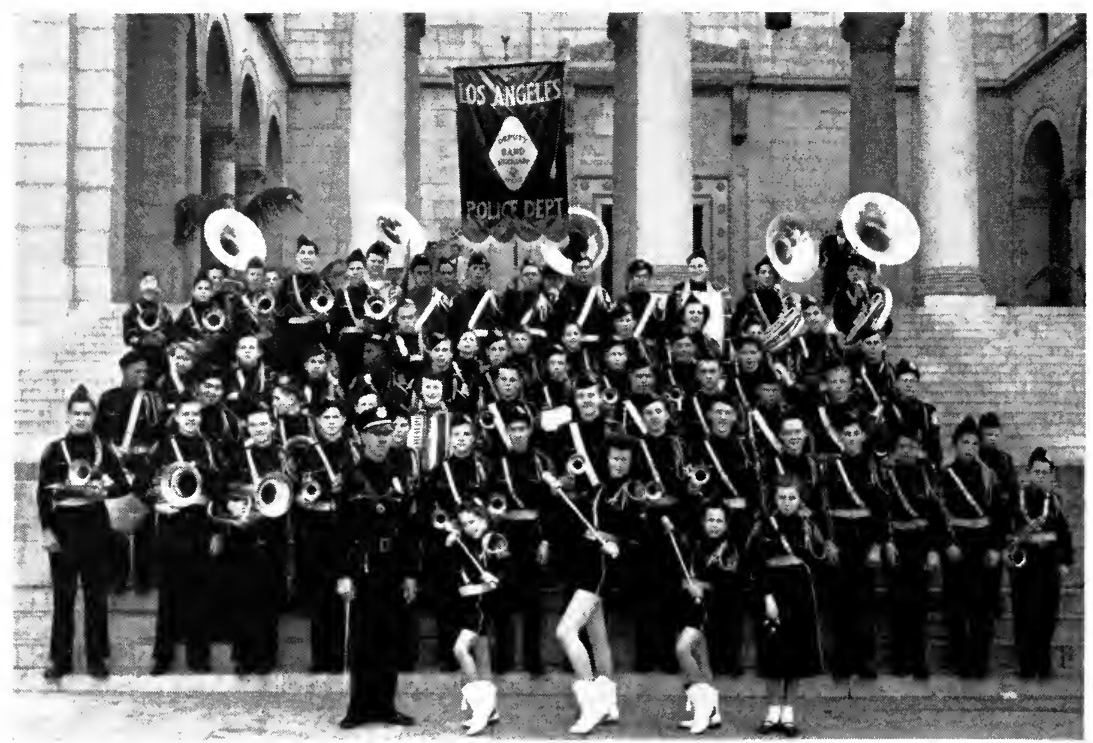

Figire 26A, B, C, D. Dhputy Alxillary Police, Los Avghles

On this and the opposite page are shown four of the many activities participated in by the Los Angeles Police Department Deputy Auxiliary Police. Such activities provide wholesome outlets for youthful energy, and make friends for the police department.

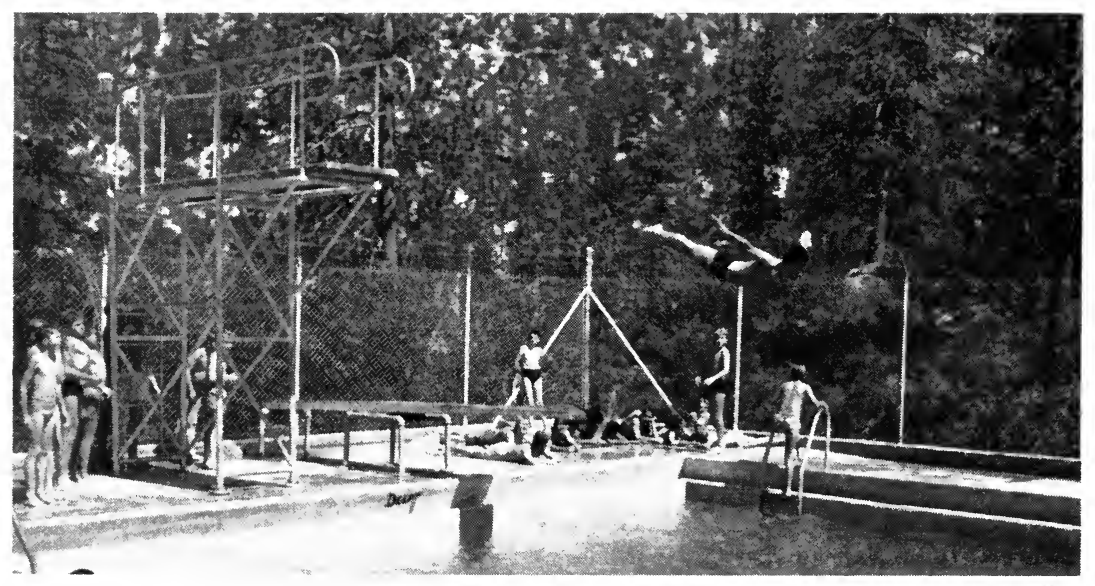



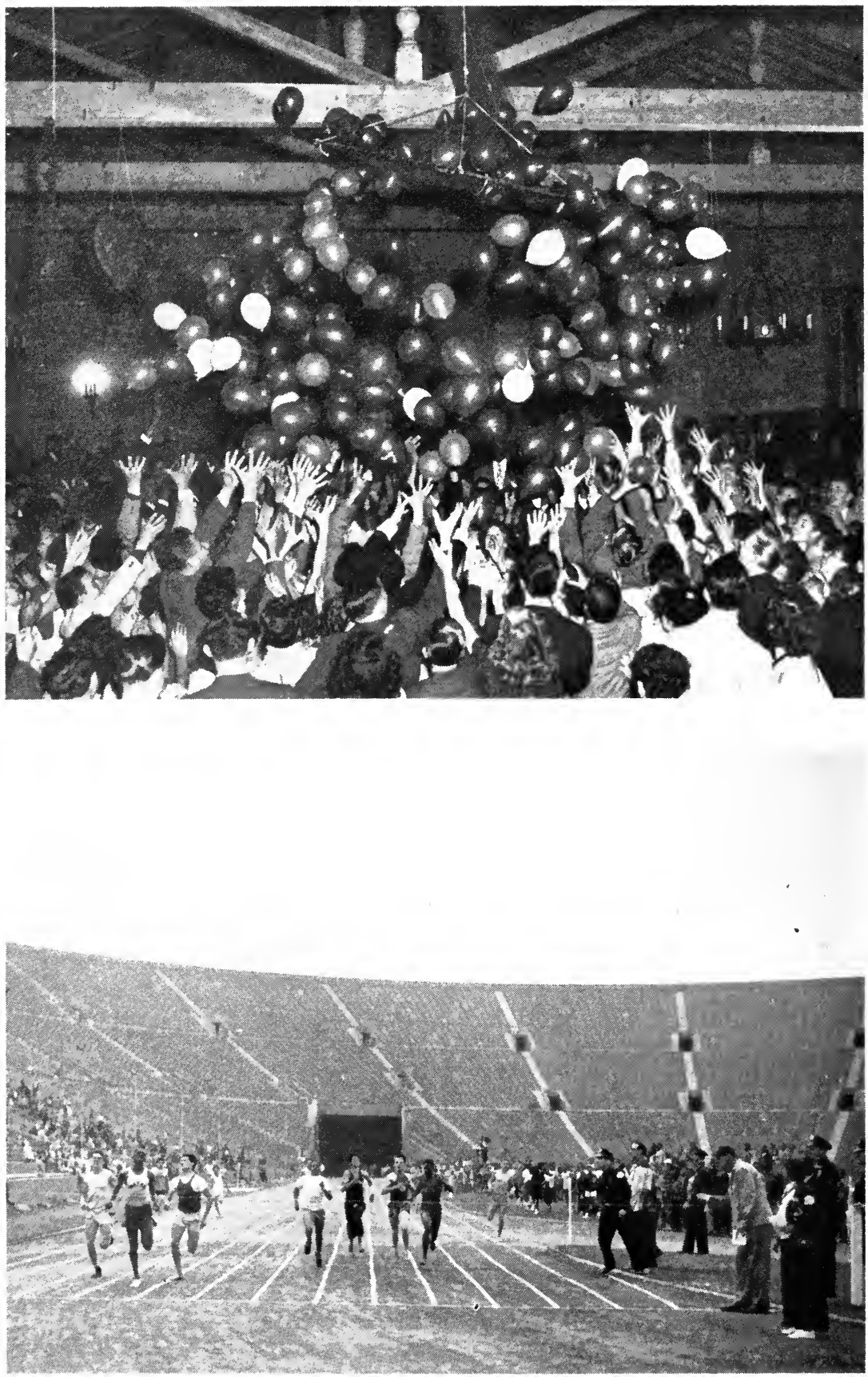


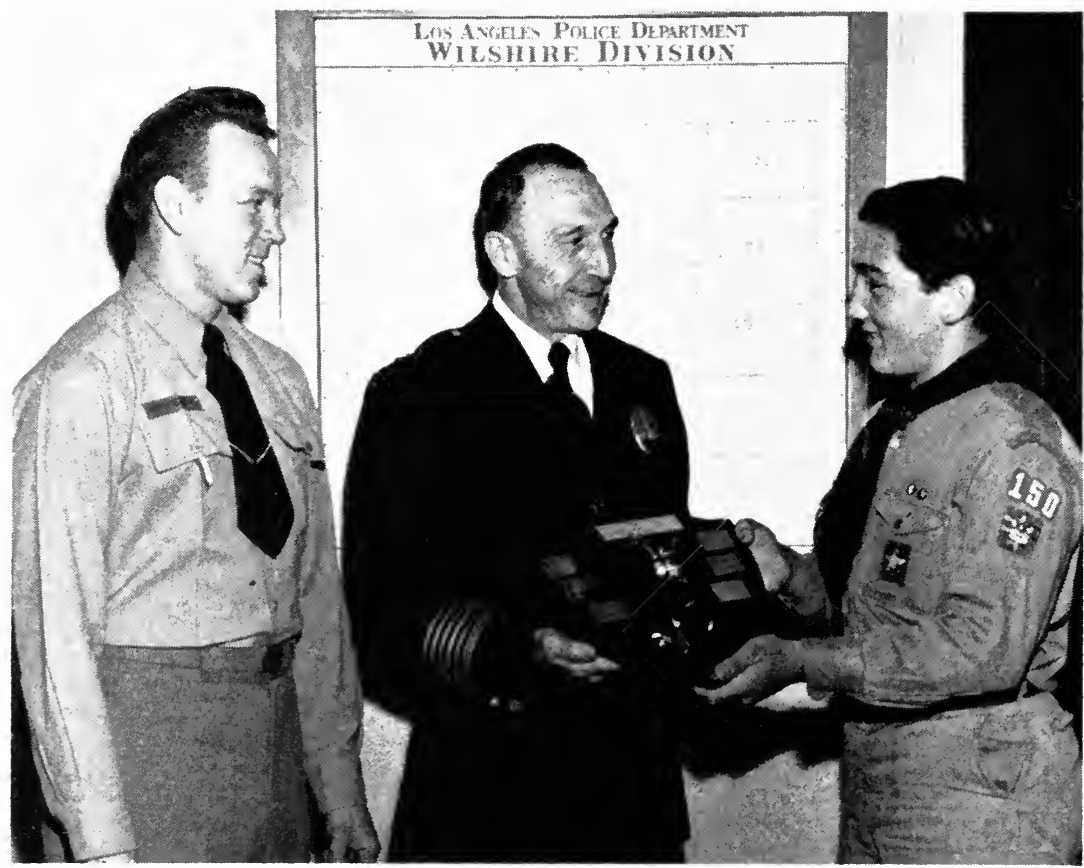

Figlre 27A AND 2-B. Police SPONSORFD BOY SCOLts

Above, a divisional captain presents an award to one of his Boy Scout leaders. Below, the "Rainbow" Troop, sponsored by the L.A.P.I)., starts on its transcontinental bus trip to the Scout Jamboree at Valley Forge, Penn.

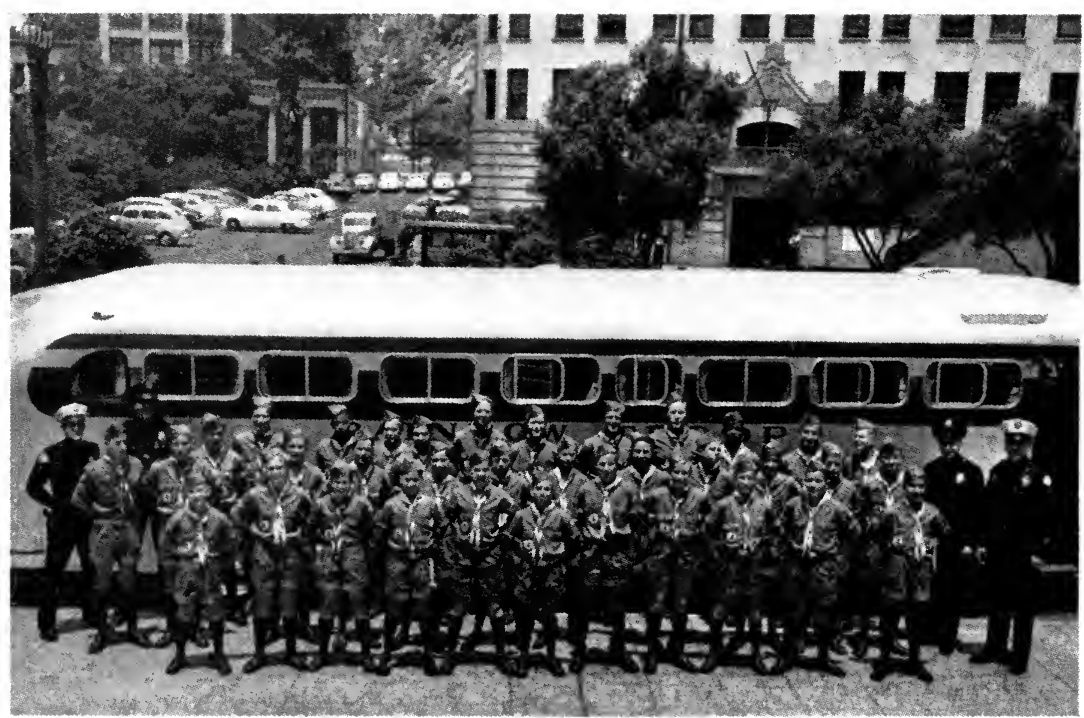


Boys And Giris: The 17 and under age group contains mostly 15 , 16, and 17-year-old boys and girls who, in most instances, are in high school. Concerning many traits, the expressed attitudes of this group are more favorable than those of the total of all respondents. This is true for the traits of Honesty, Training, Selection, Equipment, Crime Prevention, Juvenile Delinquency, Investigation and Apprehension, Treatment of Suspects, and Supervision.

The statements of the youngest group regarding the Attitudes of Boys and Girls toward Los Angeles Policemen are particularly valuable because they are in a better position than any other age group to know how they themselves feel. That the police are liked by boys and girls is the expression of 35.2 per cent of the youngest group; while 39.5 per cent believe that boys and girls are indifferent toward the police, and $\mathbf{1} 8.2$ per cent actually fear the police. These figures should be compared with averages for all respondents; which are 37.1 per cent, 27.4 per cent, and 14.9 per cent, respectively. This is the only trait which is marked by the youngsters less favorably than by all respondents-all others are marked at least as favorably. The attitude of this young group toward Juvenile Delinquency is of particular interest. For instance, 64.8 per cent of them express a belief that Los Angeles Policemen are usually watchful to prevent juvenile delinquency; whereas, an average of only 53.7 per cent of all respondents express the same opinion, and only 4.3 per cent of the boys and girls indicate that the police are indifferent concerning juvenile delinquency, as compared with 7.9 per cent of all respondents who express this same attitude.

Strength of Convictions: The young adults-i 8 to 2 f years of age-are the most positive in their opinions; and the oldest men and women are more inclined to admit that they do not know how to rate Los Angeles Policemen as regards many of the listed traits. This is indicated, to some extent, by the Over-all Evaluation, but more clearly by other specific traits. In the 55 and over age group, 17.6 per cent admit that they do not know how to rate the Los Angeles Police Department in comparison with other large police departments; while only 10.8 per cent of the 18 to 24 age group confess they do not know. In the 55 and over age group 3.8 per cent, and in the 18 to 24 group only .8 per cent, say they do not know how to rate the Appearance of Los Angeles Police Officers. 
Comparable figures for some of the other traits, showing percentages of the 55 and over and the 18 to 24 year age groups who do not know how to rate Los Angeles Policemen, appear below.

\section{Education}

Honesty

Courtesy

Training

Equipment and Facilities

Crime Prevention

Juvenile Delinquency

Treatment of Suspects
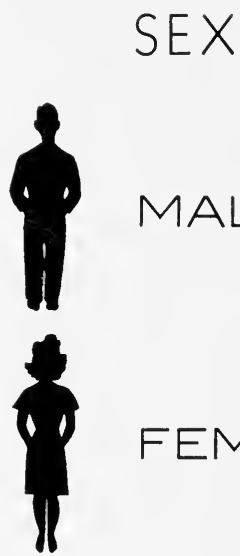

\section{MALE}

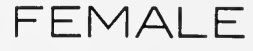

Fifty-five and Over

$\begin{array}{rr}21.9 & 11.6 \\ 21.1 & 11.2 \\ 15.0 & 2.7 \\ 23.9 & 11.0 \\ 34.5 & 17.5 \\ 21.9 & 7.5 \\ 22.5 & 6.6 \\ 36.5 & 17.7\end{array}$

PER CENT

\section{KEY}

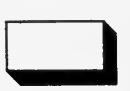

One of the very

best Police Departments

in the country

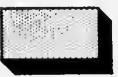

About on an average

with other large

Police Departments

Definitely below standard

in comparison with other

large Police Departments

Do not know

\section{Figure 28}

Orer-All Evaluation ey Sex of Respondents.

Distribution of multiple-choice ratings of Los Angeles

Policemen by sex of respondents. 


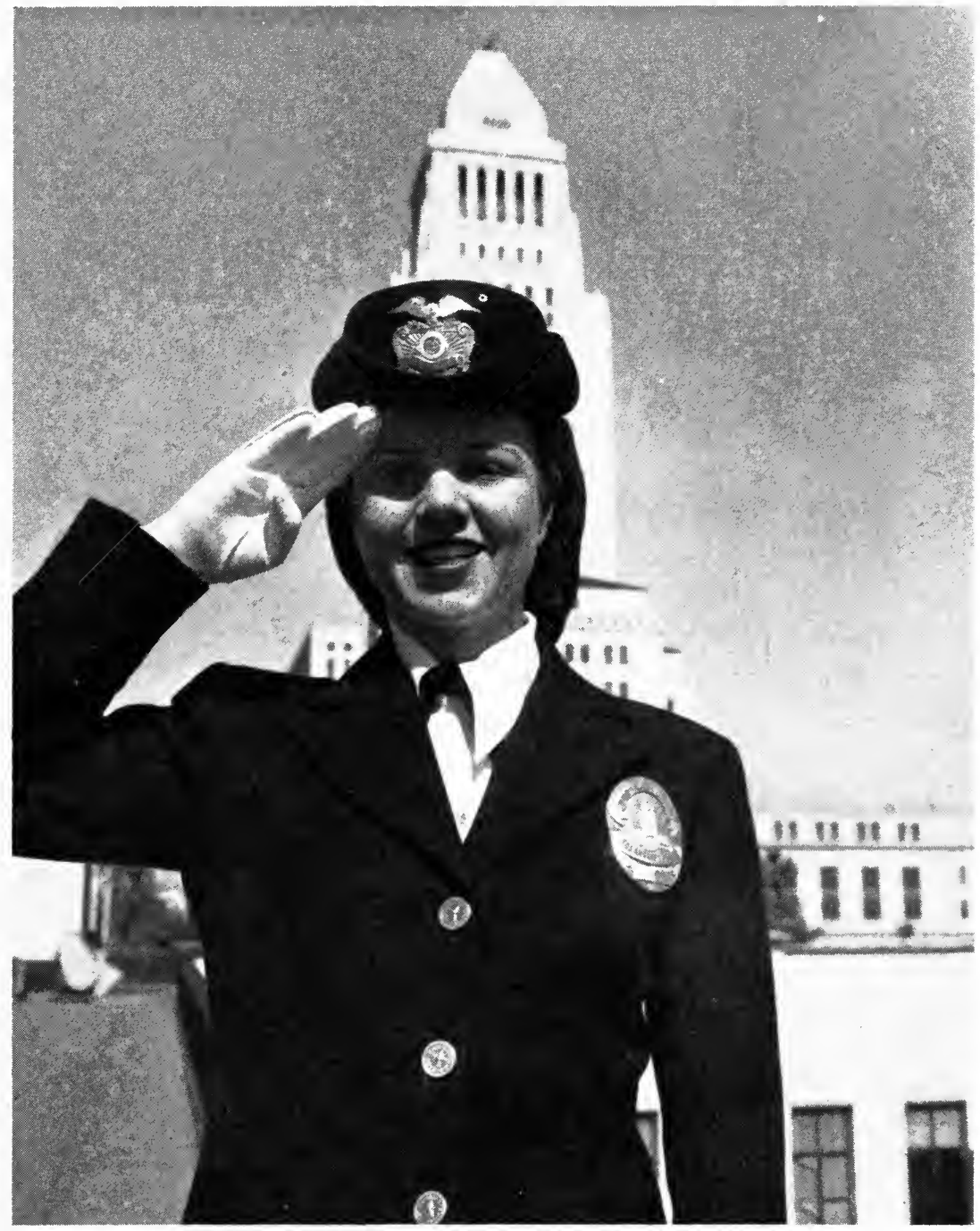

Figure 29. A Los Angeles Policewoman

Policewomen perform necessary and valuable services in a modern police department. 


\section{SEX}

More Favorable Attitude of Males: The males in Los Angeles look upon the police department more favorably than do the females. This is true not only for the Over-all Evaluation (see Figure 8) but for most all of the specific traits.

It is to be noted that while each of the sexes casts about an equal percentage of its votes in the middle and bottom brackets, 32.2 per cent of the males, and only 21.7 per cent of the females, state that their police department is one of the very best in the Country.

Lack of Knowledge by Females: It is interesting to observe that for almost every trait the percentage of males and females who place Los Angeles Policemen in the middle or bottom brackets are approximately the same; while the percentage of males who place the police in the top bracket is much higher than that for the females. On the other hand, the percentage of females who admit they do not know how to rate the Los Angeles Policemen is, in every case, higher than the males. For almost every trait, there are about twice as many females as males who confess they are not in a position to judge.

Appearance and Physical Condition: The only traits for which the females rate the policemen higher than do the males are Appearance and Physical Condition. For instance, $7^{6.2}$ per cent of the females and 70.o per cent of the males feel that the police officers dress to command public respect; whereas, only .5 per cent of the females and .6 per cent of the males feel that they habitually dress sloppily. Fifty-six and nine-tenths per cent of the females and 48.9 per cent of the males believe that the officers are mostly in excellent physical condition; and only .8 per cent of the females and 1.o per cent of the males believe that they are mostly in poor physical condition. 


\section{Chapter VI \\ SOCIOLOGICAL FACTORS}

\section{NATIONALITY}

$\mathrm{O}$ VER-All AtTrtudes: A tabulation by nationalities or, more accurately, ethnic groups, would appear to indicate that the Negro is more inclined than others to look upon the Los Angeles Police Department with a critical eye. Only 14.4 per cent of the Negro respondents express a belief that theirs is one of the very best police departments in the Country; whereas, 22.8 per cent of the Mexicans, and 30.0 per cent of the "Whites" feel this way. It should also be observed that 20.3 per cent of the Negroes, 14.5 per cent of the Mexicans, and only 8.5 per cent of the "Whites" state that the Los Angeles Police Department is below standard in comparison with other large police departments.

Attitudes Regarding Specific Traits: These same relative opinions are found by an examination of the statements about the more specific traits, particularly the more intangible ones, made by the three major nationality groups.

As examples: 31.8 per cent of the "White" respondents, 26.2 per cent of the Mexican respondents, and only 14.0 per cent of the Negro respondents are convinced that the Los Angeles Policemen are mostly men of unquestionable honesty; whereas, 2.0 per cent of the "Whites," 5.o per cent of the Mexicans, and 9.1 per cent of the Negroes state that the police are mostly men who are dishonest. Also, 34.8 per cent of the "Whites" express a belief that the Los Angeles Police always respect the Constitutional Rights of suspected criminals; whereas, only 21.2 per cent of the Mexicans, and 12.1 per cent of the Negroes express the same opinion. Furthermore, 11.1 per cent of the "Whites," 44.4 per cent of the Mexicans, and 38.2 per cent of the Negroes believe that the police are often conscienceless and brutal in performing their duties.

For the most part, the Mexican respondents express attitudes toward Los Angeles Policemen which are less favorable than the "Whites," but more favorable than the Negro respondents. 


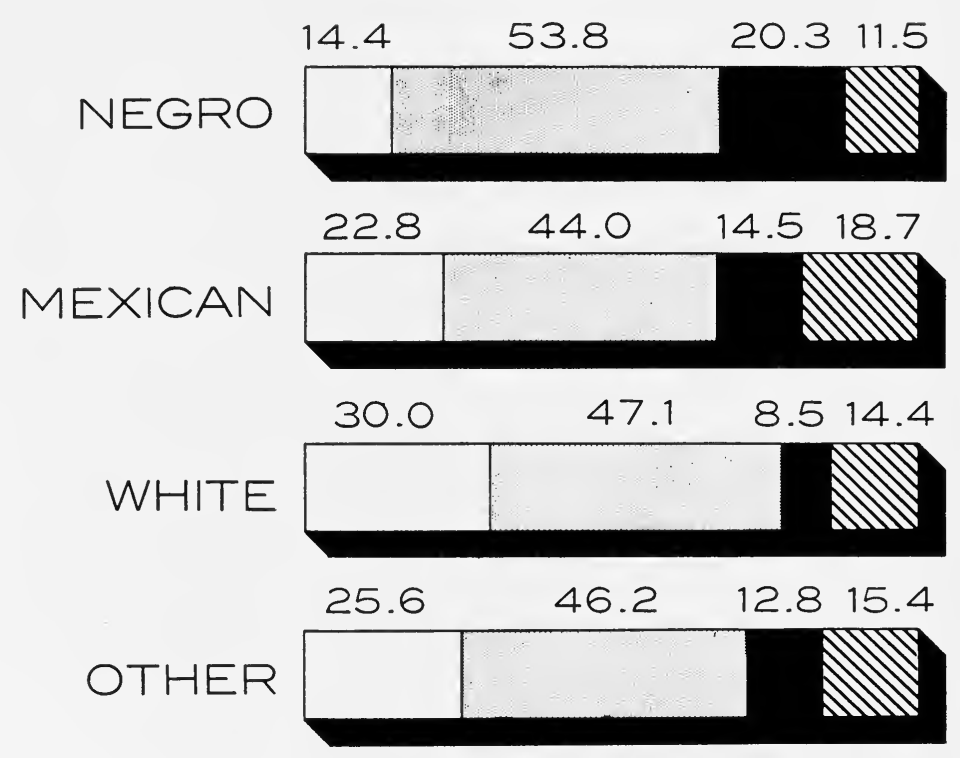

KEY

One of the very

best Police Departments in the country

Distribution of Sample

About on an average

with other large

Police Departments

Definitely below standard

in comparison with other

large Police Departments

Total No.

In Sample Percent

\begin{tabular}{lrr} 
Negro & $34^{0}$ & 10.9 \\
Mexican & $24^{1}$ & 7.8 \\
White & 2402 & 77.5 \\
Other & 117 & 3.8 \\
& & \\
\cline { 2 - 3 } & 3100 & 100.0
\end{tabular}

Do Not Know

Figure 30

Over-All Evaluation by Nationality

Distribution of multiple-choice ratings of Los Angeles

Policemen by nationality of respondents. 
Exceptions to Over-All Attitudes: There are, however, several exceptions to this general rule. For instance, 73.0 per cent of the Mexican respondents, and only 55.9 per cent of the Negro, and 68.1 per cent of the "White" respondents, believe that Los Angeles Policemen are usually men of high school education or higher. On the other hand, 5.8 per cent of the Mexicans, 2.3 per cent of the Negroes, and only .9 percent of the "Whites" believe the policemen are usually men of little or no education.

More Mexicans than Negroes or "Whites" feel that Los Angeles Policemen are highly trained in modern police methods. The percentages are: $5^{\text {o. }} 6$ per cent for the Mexicans, 43.8 per cent for the "Whites," and 32.9 per cent for the Negroes.

As high a percentage of Mexican as "White" respondents place the Los Angeles Policemen in the top bracket for the topics of Basis of Selection, Discipline, Influence of Politics, and Top Administration. On the other hand, the percentage of Mexicans who place the police in the lowest category for each of these same traits is higher than the "Whites."

Strength of Convictions: The "White" respondents admit they do not know how to rate Los Angeles Policemen as regards the various traits far more often than do the other respondents. In fact, only for Appearance and Physical Condition do they appear more positive than the others.

The Mexicans appear to be most sure of their opinions, particularly as regards Treatment of Suspects, Education, Courtesy, Training, and Attitudes of Boys and Girls. For instance, the respondents who say they do not know how Los Angeles Policemen treat suspects include 26.9 per cent of the "Whites," 16.5 per cent of the Negroes, and only 9.5 per cent of the Mexicans.

The Negro respondents indicate that they are less sure than the other respondents in checking Appearance, Physical Condition, Courtesy, and Equipment and Facilities. As regards the strength of their convictions concerning Honesty, Crime Prevention, Juvenile Delinquency, and Influence of the Press, the groups are about evenly divided. 


\section{MARITAL STATUS}

Significance: Marital status does not appear to be a significant factor in influencing attitudes toward the police. If any one marital classification is more favorably inclined toward Los Angeles Policemen than the others, it is the married group. This group cast a slightly higher percentage of its votes than did the others in the top bracket for the traits of Education, Departmental Discipline, Equipment and Facilities, Influence of Politics, Crime Prevention, Influence of the Press, Treatment of Suspects, Attitudes of Boys and Girls, Minority Groups, Protection of the Innocent, Supervision, and Top Administration, as well as the Over-all Evaluation.

The single respondents selected the top bracket in which to rate policemen more often than did the others for the traits of Training, Basis of Selection, Juvenile Delinquency, and Investigation and Apprehension; whereas, the widowed respondents expressed the most favorable attitudes regarding Appearance, Physical Condition, Courtesy, and Professional Interest.

The divorced respondents failed to rate Los Angeles Policemen higher than did the other marital groups for a single trait, and did rate slightly lower than did the other groups for the traits of Honesty, Crime Prevention, Juvenile Delinquency, Investigation and Apprehension, Treatment of Suspects, Protection of Innocent, Supervision, and Over-all Evaluation.

Over-all Evaluation: Concerning the Over-all Evaluation, 3o.o per cent of the married respondents, 27.7 per cent of the widowed respondents, 24.3 per cent of the single respondents, and 22.0 per cent of the divorcees express a belief that the Los Angeles Police Department is one of the very best in the Country. On the other hand, 11.4 per cent of the single, 11.3 per cent of the divorced, 9.9 per cent of the married, and only 7.6 per cent of the widowed respondents state that the Los Angeles Police Department is below standard in comparison with other large police departments.

Strength of Convictions: The most significant factor appears in the "Do Not Know" column. For every trait the widowed respondents state that they do not know how to rate Los Angeles Policemen far more frequently than do the other respondents. 
As an example, 30.0 per cent of the widowed respondents indicate that they do not know how to rate the Los Angeles Department in comparison with other large police departments; whereas, an average of only 14.4 per cent of all respondents confess they do not know.

In evaluating the tabulations by marital status, it should be borne in mind that the groups will have different average-ages. Obviously, the single respondents will be younger on an average than will those who are widowed. Differences in ages may well be more instrumental in affecting attitudes of respondents than are differences in marital status.

\section{EDUCATION}

Composition of the Sample: In the sample, 10.2 per cent of the respondents have completed only the eighth grade or less; 18.5 per cent attended high school, but did not graduate (that is, they completed the ninth, tenth, or eleventh grade); 25.1 per cent graduated from high school, or at least finished the twelfth grade; 23.3 per cent had some college training (that is, they finished one, two, or three years of college); 8.8 per cent are college graduates (four years of college); 7.0 per cent completed some graduate work (five or more years of college); and 7.1 per cent did not state how many years of schooling they had completed.

General Trend: Although variations in attitudes among the educational groups outlined above are not great, there is, nevertheless, a definite trend among the respondents with the least schooling to look most favorably upon the police, and for the college graduates to look upon them with the least approval.

Over-all Evaluation: In their over-all evaluation, 31.3 per cent of the respondents who have completed the eighth grade or less state that the Los Angeles Police Department is one of the very best in the Country; whereas, an average of 27.6 per cent of all respondents, and only 20.1 per cent of the college graduates, express the same belief; 12.4 per cent of the college graduates, and only 9.8 per cent of the respondents with an eighth-grade education or less, answer that they think the Los Angeles Department is definitely below standard in comparison with other large police departments. 


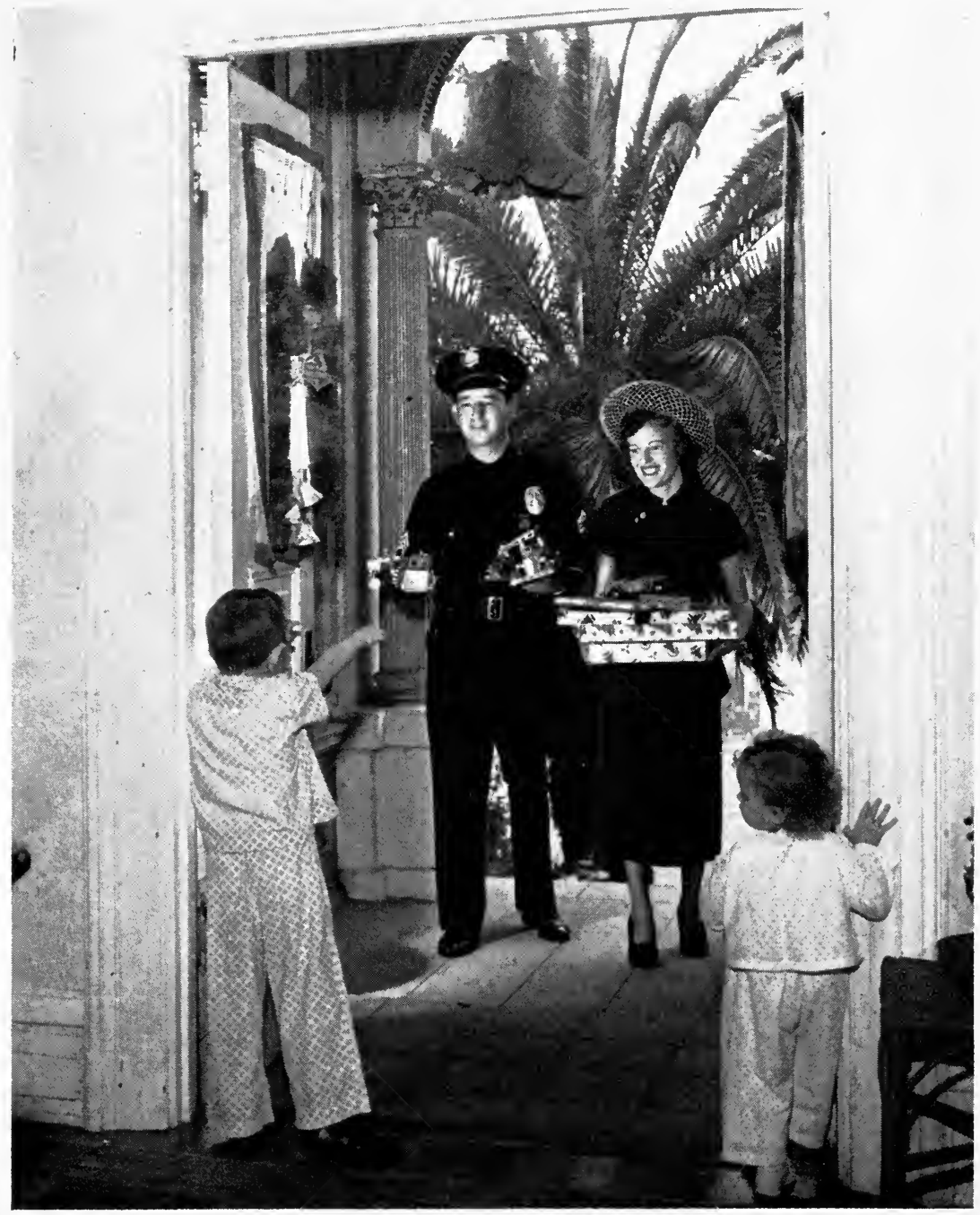

Figure 31 A ANd 31 B. Community Activity

Above, a sergeant of police and his wife bring toys to an orphanage at Christmas time. Opposite page, policemen donate blood to the Red Cross for G. I.'s in Korea. 


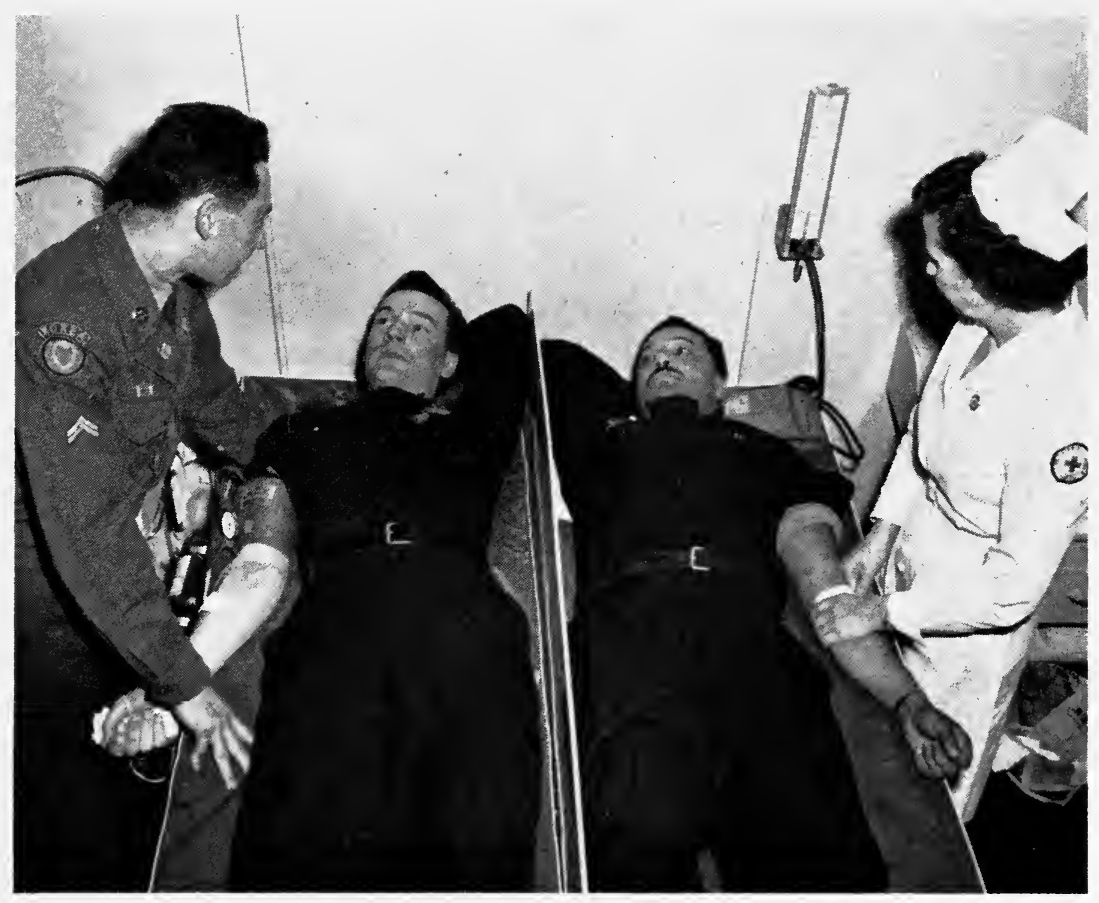

Evaluation of Specific Traits: The more favorable attitudes of the lowest educational group are closely approximated by the respondents who have completed the ninth, tenth, and eleventh grades and, frequently, by the high school graduates. The three lower educational groups give the most favorable responses for all traits except Appearance, Physical Condition, and Education. The college graduates, more frequently than other respondents, state that the Los Angeles Officers dress to command public respect; whereas, those with five or more years of college say more frequently than the other respondents that Los Angeles Policemen are mostly in excellent physical condition.

For 19 of the 22 traits listed in the questionnaire, the college graduates and those with five or more years of college training rate Los Angeles Policemen in the top bracket less often than do the respondents with less formal schooling. For instance, 29.2 per cent of all respondents, 22.6 per cent of the college graduates, and only 18.5 per cent of the respondents with five or more years 
of college training claim that Los Angeles Policemen are men of unquestionable honesty; 32.2 per cent of all respondents, 26.3 per cent of the college graduates, and 25.9 per cent of the respondents with five or more years of college training state that Los Angeles Policemen are habitually courteous in dealing with the public; 21.3 per cent of all respondents, 11.3 per cent of the college graduates, and 11.1 per cent of those with five or more years of college training express the conviction that Los Angeles Policemen apprehend criminals indiscriminately without regard for influential persons.

\section{LENGTH OF RESIDENCE}

Strangely enough, there seems to be a good deal of competition between the newest and oldest residents as to which will look most favorably upon the Los Angeles Police Department. Thirty and seven-tenths per cent of the respondents who have resided in the city 10 years and over, and 29.2 per cent of those who have lived here less than one year (as compared with an average of 27.6 per cent of all respondents) express the opinion that theirs is one of the very best police departments in the Country; whereas, 8.5 per cent of the oldest residents, 6.2 per cent of the newest residents, and an average of 10.4 per cent of all respondents, state that it is below standard in comparison with other large police departments.

The respondents who have lived in the city for 10 years and over place their policemen in the top bracket more often than do other respondents for the traits of Appearance, Physical Condition, Education, Minority Groups, Protection of Innocent, and Top Administration. The respondents who have resided here less than one year place the Los Angeles Policemen in the top bracket more often than do the respondents of longer residence for the traits of Honesty, Courtesy, Professional Interest, Training, Basis of Selection, Equipment and Facilities, Crime Prevention, Influence of the Press, Investigation and Apprehension, Treatment of Suspects, Attitudes of Boys and Girls, and Supervision.

Not much of significance can be observed in the "Do Not Know" column as there is a good deal of variation from trait to trait. 


\section{LENGTH OF RESIDENCE PER CENT}

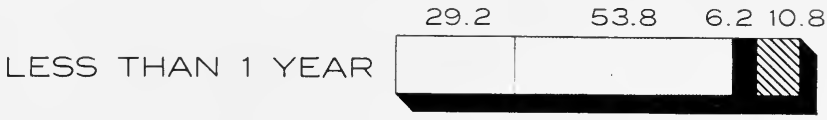

1 YEAR - LESS THAN 2 YEARS $\begin{array}{lll}23.3 & 48.9 \\ & \end{array}$

2 YEARS - LESS THAN 5 YEARS \begin{tabular}{|l|l|l|l|l|l|l|}
24.0 & 50.2 & 13.8 & 120 \\
& & &
\end{tabular}

5 YEARS - LESS THAN 10 YEARS

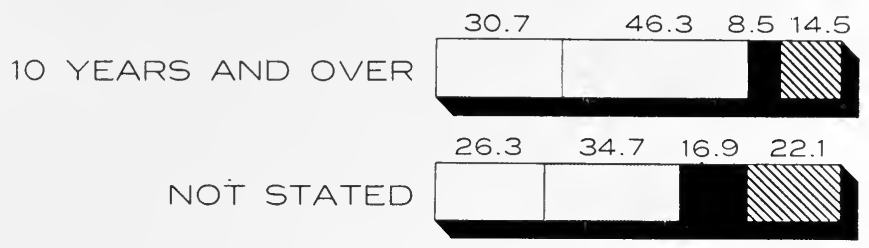

KEY

One of the vers

best Police Departments

in the Country

About on an average

with other large

Police Departments

Definitely below standard

in comparison with other

large Police Departments

Do not know
Distribution of Sample

Total No.

in Sample Percent

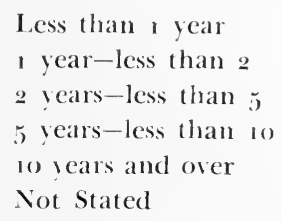

Less than I year

1 year-less than 2

2 years-less than 5

5 vears-less than 10

10 years and over

Not Stated

$\begin{array}{rr}65 & 2.1 \\ 90 & 2.9 \\ 426 & 13.7 \\ 44^{6} & 14.4 \\ 197^{\circ} & 63.8 \\ 9.5 & 3.1 \\ -- & --- \\ 3100 & 100.0\end{array}$

FIGURE 32

Ovfr-Ait, Evaluation by Length of Risidence

Distribution of multiple-choice ratings of Los Angeles

Policemen by length of residence of respondents. 
Although there is no way of knowing, for certain, the slightly more favorable attitudes of the respondents who have lived in Los Angeles less than one year may be due, in part, to the fact that they were not exposed to unfavorable newspaper publicity arising from an alleged case of "police corruption" occurring a year prior to this survey.

The more favorable attitudes of the respondents who have resided in the city for 10 years or more may have resulted, in part, from a longer acquaintanceship with their police department and, consequently, they may have been less influenced by the adverse publicity. 


\section{Chapter VII \\ OCCUPATION}

\section{DISTRIBUTION OF SAMPLE}

The nistribution of respondents into occupational groups showing number and per cent of each group in the total sample is as follows:

Occupation
Salespeople or Agents
Clerical
Commercial
Professional
Public Servants
Skilled Laborers
Unskilled Laborers
Housewives
Students
Miscellaneous
Not Stated
$\quad$ TOTAL

\begin{tabular}{cc} 
Total Number & \\
in Sample & Per Cent \\
163 & 5.3 \\
370 & 11.9 \\
99 & 3.2 \\
288 & 9.3 \\
175 & 5.6 \\
587 & 18.9 \\
84 & 2.7 \\
430 & 13.9 \\
567 & 18.3 \\
172 & 5.6 \\
165 & 5.3 \\
\hline 3100 & 100.0
\end{tabular}

PUBLIG SERVANTS

Special attention is called to the Public Servants, as $15^{2}$ of these 175 respondents are policemen. It must also be observed, however, that 132 of the 152 were (at the time they filled in the questionnaire) in the Los Angeles Police Training Academy, and had been policemen for only three weeks.

It is not surprising then that 77.7 per cent of the Public Servants proclaim, in answer to the survey, that Los Angeles has one of the very best police departments in the Country, as compared with 27.6 per cent of all respondents who make the same claim.

This more favorable attitude of the Public Servants is also expressed for most traits considered in the questionnaire. There are, however, a few interesting and, perhaps, surprising exceptions. Only 17.7 per cent of the Public Servants, as compared with 32.2 per cent of all respondents, express a belief that policemen are 
habitually courteous in dealing with the public; 28.5 per cent of the Public Servants, as compared with 52.3 per cent of all respondents, indicate that Los Angeles Policemen are mostly in excellent physical condition; and only 64.6 per cent of the Public Servants, as compared with 72.6 per cent of all respondents, think that Los Angeles Policemen dress to command public respect.

\section{UNSKILLED LABORERS}

Other than the Public Servants, apparently the occupational group most favorably inclined toward the Los Angeles Police Department is that of Unskilled Labor. In this group are 23 janitors, 20 watchmen, 15 laborers, 14 factory workers, and 12 others.

Apparently, the Unskilled Laborers have more confidence in the honesty of their policemen than do the Public Servants; for 44.0 per cent of them, as compared with only 4 o.o per cent of the Public Servants, state that Los Angeles Policemen are mostly men of unquestionable honesty.

Regarding the courtesy of Los Angeles Policemen, the most favorably impressed are the Unskilled Laborers; for 47.6 per cent of them, as compared with 32.2 per cent of all respondents, and only 17.7 per cent of the Public Servants, express a conviction that Los Angeles Policemen are habitually courteous in dealing with the public.

Training, too, receives a higher vote of confidence from the Unskilled Iaborers than from the Public Servants; for 57.1 per cent of the Unskilled Laborers, 49.2 per cent of the Public Servants, and 43.0 per cent of all respondents, state that Los Angeles Policemen are highly trained in modern police methods.

As high a percentage of Unskilled Laborers as Public Servants feel that the policemen have a high professional interest in their work-41.7 per cent of each having answered the questionnaire to this effect.

The Unskilled Laborers rated all traits except two higher than did all respondents. The two traits are Appearance and Over-all Evaluation.

\section{SKILLED LABORERS}

The attitudes of the Skilled Laborers are found, in most instances, to be slightly less favorable than those of Unskilled La- 
borers, but more favorable than the attitudes of all respondents. The Skilled Laborers rated all traits except two-Attitudes of Boys and Girls and Protection of Innocent-higher than did all respondents.

\section{TRANSPORTATION WORKERS}

Significant results are obtained by a study of this group divided into transportation workers and all others (see Figure 11 ). Of the $5^{87}$ Skilled Laborers, 235 -or 4 o.o per cent-are transportation workers. These include the following specific occupations, together with the indicated number and per cent of each.

$\begin{array}{lcc}\text { Occupation } & \text { Number } & \text { Per Cent } \\ \text { Taxi Driver } & 44 & 18.7 \\ \text { Bus Driver } & 40 & 17.0 \\ \text { Streetcar Man } & 124 & 52.7 \\ \text { Truck Driver } & 22 & 9 \cdot 4 \\ \text { Teamster } & 2 & .9 \\ \text { Transportation } \quad \underline{3} & 1.3 \\ \quad \text { ToTAL } & 235 & 100.0\end{array}$

It is both interesting and significant to note that the transportation workers, who are in daily contact with the police and who are, frequently, in a better position than others to judge, rate policemen consistently higher than do other Skilled Laborers. For every one of the 22 traits listed, the transportation workers rated their policemen higher than did the other Skilled Laborers. For instance, 31.5 per cent of the transportation workers, and only 25.8 per cent of all others, state that Los Angeles has one of the very best Police Departments in the Country. Differences in ratings for specific traits are even more pronounced. That the policemen dress to command public respect was expressed by 85.1 per cent of the transportation workers; whereas, only 66.7 per cent of the other Skilled Laborers expressed this same opinion.

Of the transportation workers, 42.1 per cent believe that Los Angeles Policemen operate under excellent discipline; whereas, only $3 \mathbf{1} .5$ per cent of the other workers feel this way. In discussing Influence of the Press, $5^{2.3}$ per cent of the transportation workers, and only 29.o per cent of the others, believe that policemen operate independently from newspaper publicity. Statements regarding Supervision indicate that 42.1 per cent of the transportation workers, and 27.8 per cent of the other Skilled Laborers, believe 
that Los Angeles Policemen are directed by highly competent and efficient supervisors.

\section{PROFESSIONALS}

Among the lowest votes of confidence were those expressed by Professionals, Students, and Housewives. The Professional Group rated lower than did the other respondents for the traits of Honesty, Discipline, Investigation and Apprehension, Treatment of Suspects, Supervision, and Top Administration.

In the Professional Group, who rated consistently low, a breakdown of actual vocations is as follows:

Vocations
School Teachers and Athletic Directors
Accountants
Engineers and Architects
Doctors, Dentists, Etc.
Attorneys
Nurses
Executives
Entertainers
Others

TOTAL

\begin{tabular}{cc} 
Number & Per Cent \\
105 & 36.5 \\
22 & 7.6 \\
21 & 7.3 \\
30 & 10.4 \\
15 & 5.2 \\
24 & 8.3 \\
19 & 6.6 \\
16 & 5.6 \\
36 & 12.5 \\
\hline 288 & 100.0
\end{tabular}

A study of a tabulation of the Professional Group by actual occupation brings to light many interesting facts. There is a wide range of opinion among the Professional occupations, and each appears to be rather consistent throughout the range of 22 items. The executives consistently rate much higher than the other professional groups. They selected the top bracket in which to rate Los Angeles Policemen more often than the others for 17 of the 22 traits. The entertainers, on the other hand, consistently rated much lower. They rated lower than all other professional groups for 11 of the traits, and highest in only one-Juvenile Delinquency.

Attorneys rated policemen lower than the other professionals for six traits; that is, Courtesy, Training, Basis of Selection, Juvenile Delinquency, Minority Groups, and Protection of Innocent. They ran a close second in rating policemen low in Honesty. For only the item of Influence of Politics did they rate higher than the other Professionals. 


\section{OCCUPATION PER CENT}

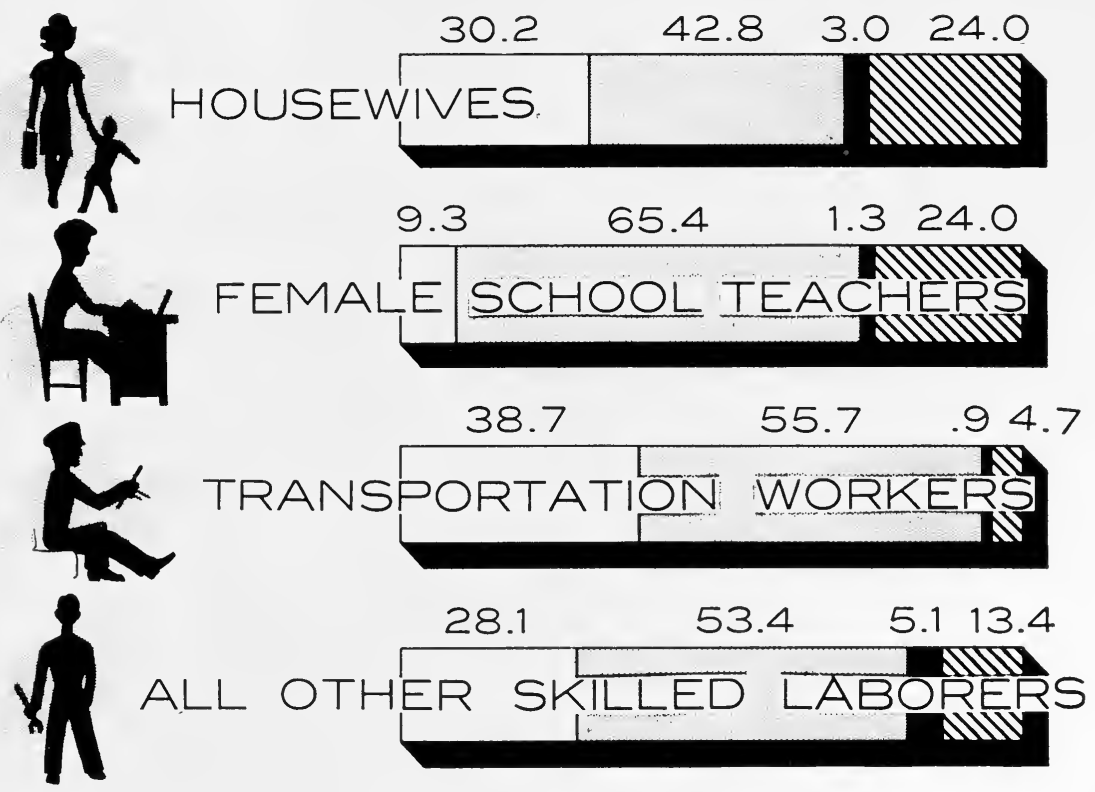

KEY
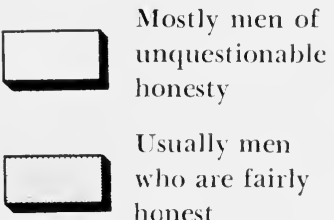

Usually men who are fairly honest

Mostly men

who are

dishonest

Do not know

\section{Distribution of Sample}

Total No. In Sample

Housewives $43^{\circ}$ Female School Teachers 75 Transportation Workers All others

\section{FIGURE 33}

Evaluation of Honesty

Distribution of multiple-choice ratings of the honesty of Los Angeles Policemen by housewives, female school teachers, transportation workers, and all other skilled laborers. 
Of interest is the fact that the doctors and dentists rated lower than all other groups for Physical Condition-and higher than all others for Protection of Innocent.

Although school teachers rated lower than other professionals for only Departmental Discipline, their expressed opinions are consistently lower than the average for all Professionals. They rated below the average of all Professionals for all traits except Appearance, Physical Condition, and Juvenile Delinquency.

The accountants rated consistently above average. For only five of the 22 traits did they express an opinion which was less flattering than that of the average of all Professionals.

\section{STUDENTS}

The Students expressed less favorable attitudes than did the other respondents for the traits of Courtesy, Professional Interest, Attitudes of Boys and Girls, and Protection of Innocent.

\section{HOUSEWIVES}

The Housewives rated policemen lower than did the other respondents for the traits of Education, Basis of Selection, Equipment and Facilities, Influence of Politics, Crime Prevention, Juvenile Delinquency, and Influence of the Press. Of all the occupational groups, the Housewives admit most of ten that they do not know how to rate Los Angeles Policemen. This is true of the Over-all Evaluation and all specific traits except Appearance and Physical Condition. The percentage of Housewives who "Do Not Know" averages, for all traits, more than fifty per cent higher than the percentage of all other respondents who "Do Not Know."

\section{FEMALE SCHOOL TEACHERS}

As unfavorable as the Housewives' ratings are, they are not nearly as unfavorable as the ratings of female school teachers. Only for Appearance do the female school teachers rate Los Angeles Policemen higher than do the Housewives. On the other hand, only 12.0 per cent of the female teachers (as compared with 26.o per cent of the Housewives) feel that theirs is one of the very best police departments in the Country; only 9.3 percent of the 


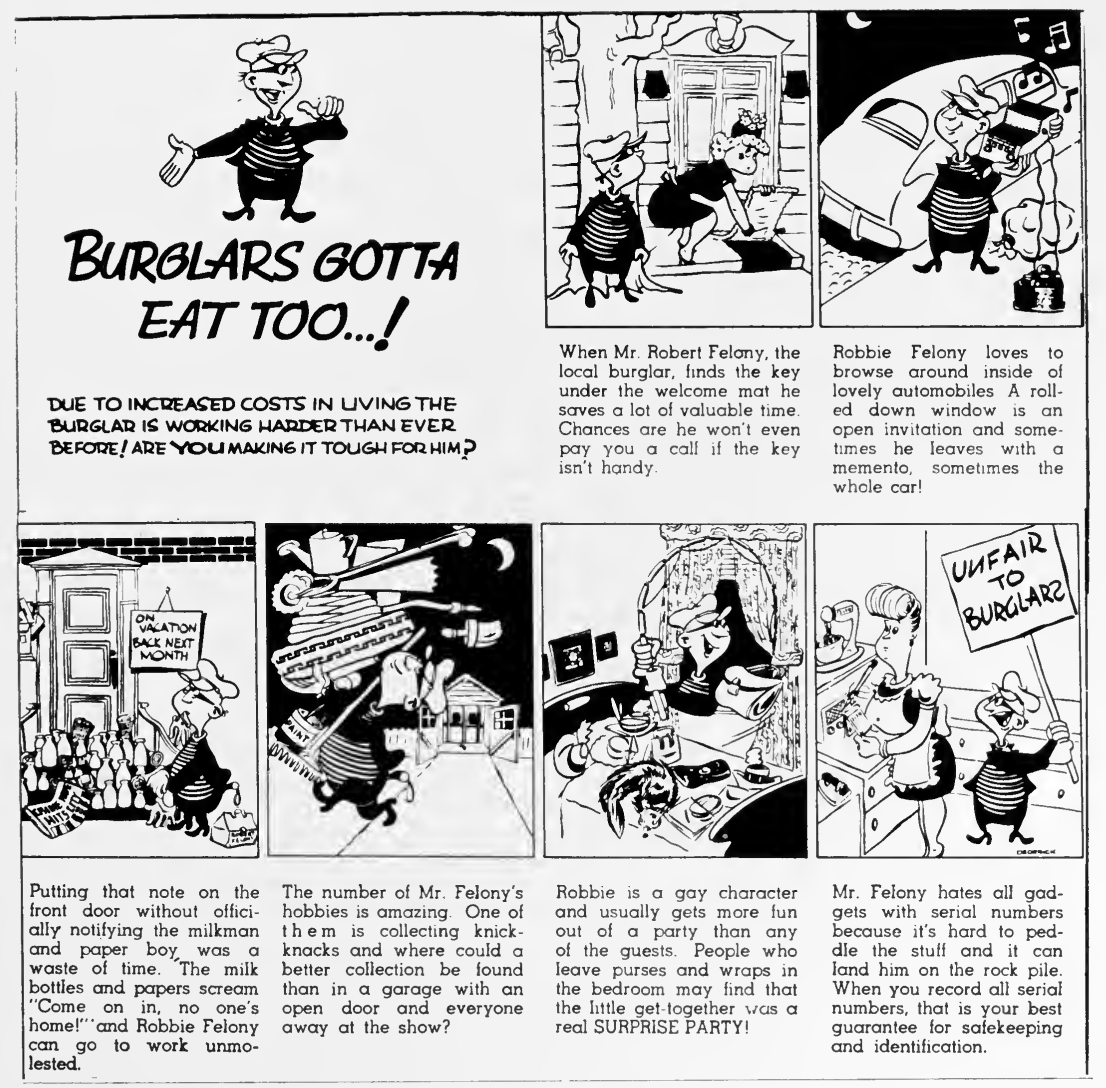

Figlike 31. A Favorable Contact with Houslwives

This educational chart was prepared for distribution to housewives. Similar favorable contacts can be made with merchants, professionals, etc.

female teachers (as compared with $3^{0.2}$ per cent of the Housewives) are convinced that Los Angeles Policemen are mostly men of unquestionable honesty; only 13.3 per cent of the female teachers (as compared with 38.1 per cent of the Housewives) believe that their police are habitually courteous in dealing with the public; only 13.3 per cent of the female teachers (as compared with 29.5 per cent of the Housewives) are convinced that Los Angeles Policemen operate under excellent discipline.

This lack of information by Housewives, together with their 
relatively low ratings on all traits, and the even lower ratings of female school teachers, would seem to indicate the need for a public relations program directed toward the women who, to so great an extent, influence the attitudes of our children-who, in turn. will become the Citizens of Tomorrow. 


\section{Chapter VIII \\ SUMMARY AND CONCLUSIONS}

\section{THE PROBLEM}

I

mportance of the Problem: The importance of good police public relations is not fully appreciated by many police departments; and many of the police agencies which do understand the seriousness of the problem have done very little toward its solution, largely because of a lack of reliable information upon which to proceed. ${ }^{1}$

The great majority of police work is done under difficult circumstances. Although appearing to a greater extent in some jurisdictions than in others, many popular and non-flattering attitudes exist toward the police. Unfortunately, at one time or another, and in one place or another, these attitudes have proved to be somewhat justified.

Old And New Duties of Police: As long as policemen confined their activities to repression, detection, and investigation of offenses which were crimes at common law, they had much public support. As the police have become increasingly charged with duties other than those which people usually consider criminal law enforcement, public support has weakened. These additional duties are often of a minor regulatory nature, rarely produce impressive social benefits, and often prove irritating to the feelings of American people, who are "rugged individualists" and believe they have a right to do as they please.

The "good citizens" of the community no longer feel a sincere alliance with the police against thieves and outlaws because, today, the multitude of regulations and traffic laws, developed by our modern civilization, have made law-breakers of us all.

It is not likely that any single instance of public action has ever been wholly satisfactory to everyone concerned, for no matter how

\footnotetext{
${ }^{1}$ Allen, Eric W.: The Public Relations Problem of the Police. The Commonwealth Review, November, 1939, p. 212.
} 


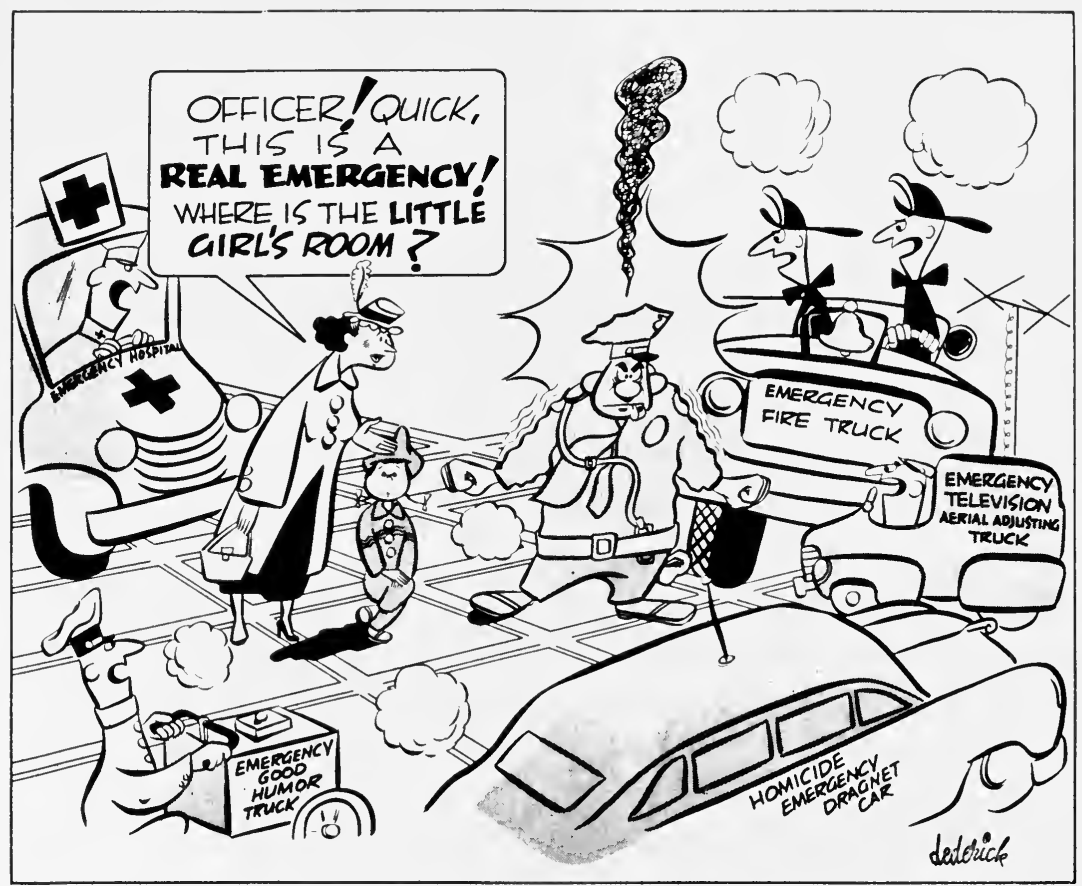

Figure 35. The Great Majority of Police Work Is Done Under Difficult Circumstances

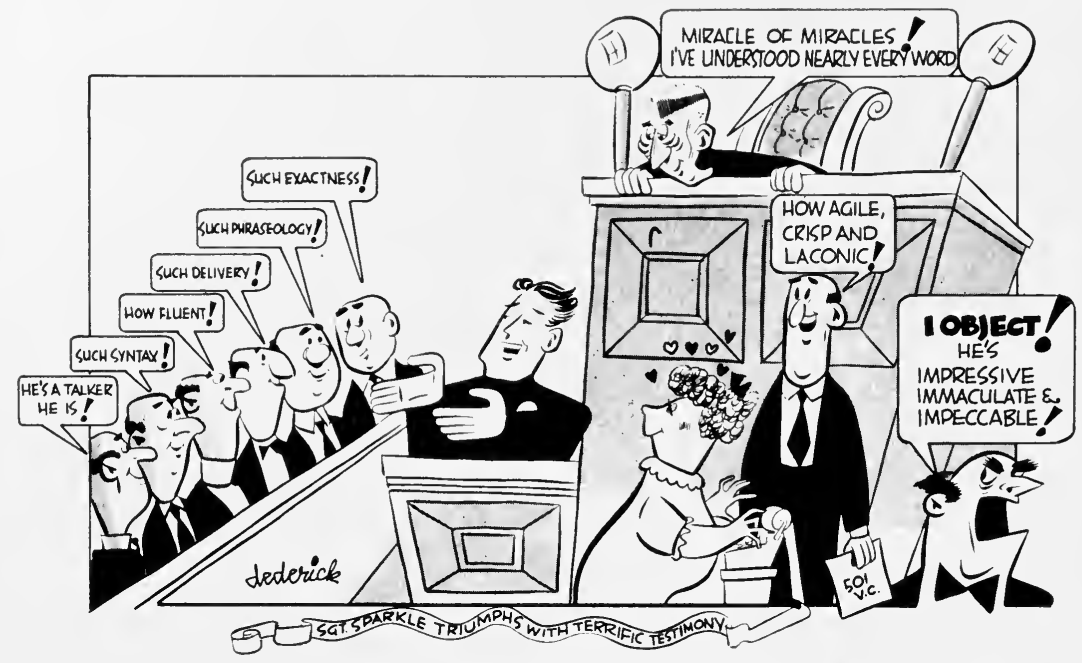

Figure 36. Public Relations in the Court Room 
efficient or brilliant the action may be, it is not likely to be viewed with enthusiasm by the thwarted or apprehended offender or his family or friends.

Need for Favorable Contacts: Despite the difficulties involved, every effort must be made to create as many favorable contacts as possible, because it is largely the sum of the multitude of daily contacts with the public that determines the degree of public acceptance or the state of police public relations. If police public contacts are made under such difficult circumstances, and are so very important to the successful operation of a police department, it would appear highly desirable to have available a device or "yardstick" to measure the status of public acceptance at any particular time, to determine which police techniques, action, and attitudes are approved-and which are not.

Selective Public Relations: The principle of selectivity has been applied very successfully in the traffic field, and to a somewhat lesser extent, in police patrol. There exists a current need for the application of this principle to police public relations so that available time, energy, and money will be most effectively applied in informing citizens who most need informing regarding the police activities about which the greatest lack of information exists; and in instructing policemen regarding modes of conduct which bring about the greatest acceptance by the public of police activities.

The present study was an experimental effort to devise an instrument and a methodology to be used as a basis for selective public relations and selective public relations training of police officers, to create a device for measuring public attitudes toward the police, and to utilize this device to measure the attitudes of local residents toward the Los Angeles Police Department.

\section{PREVIOUS ATTITUDE SURVEYS}

Although many attitude surveys have been made in the fields of political science and market research, relatively little has been done concerning police. Intelligent estimates are constantly being made by police administrators, and others, regarding the nature and extent of public attitudes; but very little of a scientific nature has 


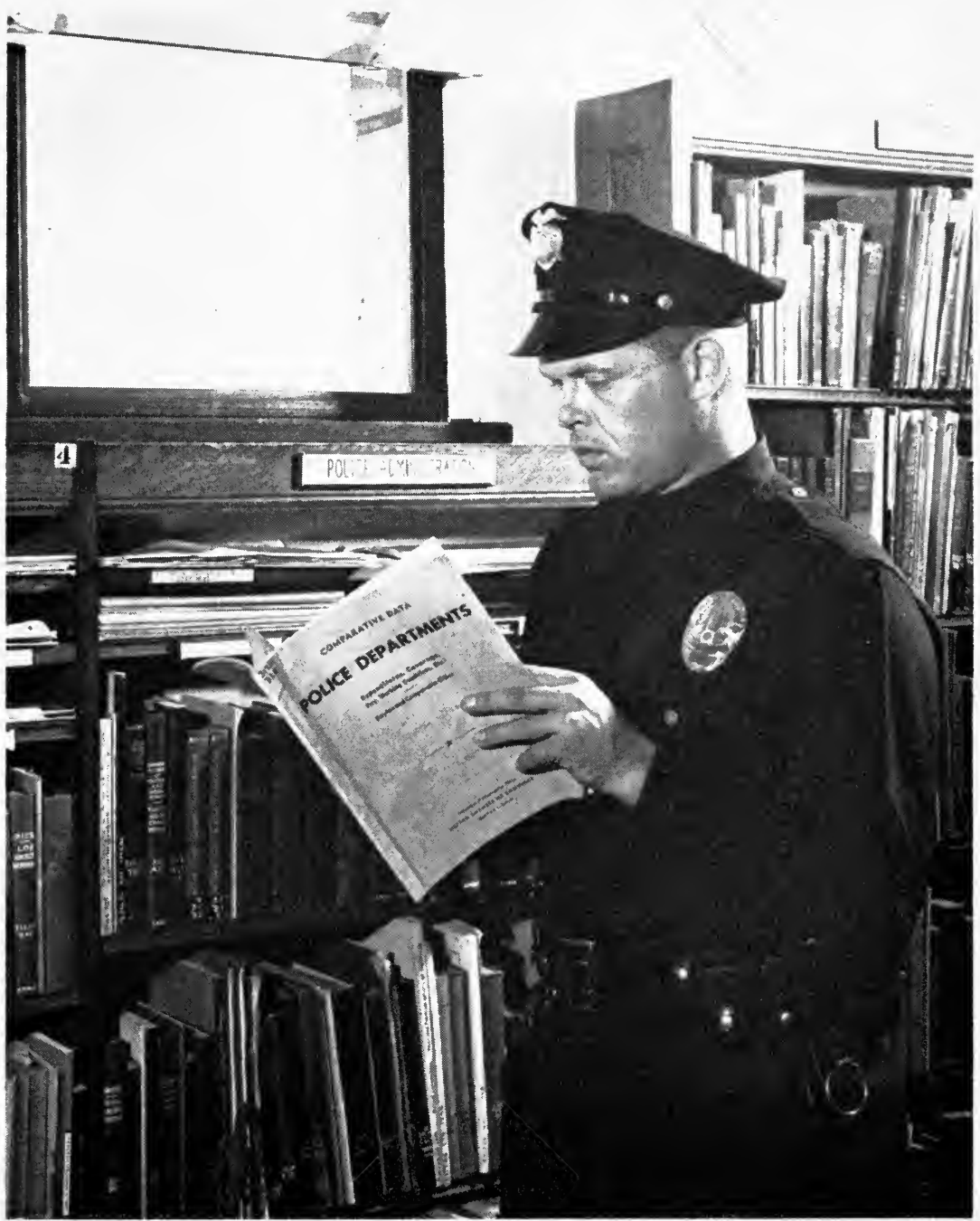

Figure 37. Training for a Modfrn Politeman

Police training can be obtained through recognized colleges and universities, zone or local recruit or in-service training schools, or by systematic self-directed study. 
been undertaken. Previous surveys of attitudes toward the police have been outlined in Chapter II.

\section{RESEARCH METHODS AND SOURCES OF DATA}

In the administration of this survey, a combination of the multiple-choice and the open-question of free-answer response was used. By this combination, it was hoped to overcome, to a large extent, the disadvantages of each.

Construction of the Questionnaire: The questionnaire devised contains three principal sections: the first listing personal or biographical data; the second setting forth twenty-two multiplechoice questions; and the third soliciting free-answer or voluntary statements as to favorable and unfavorable contacts which the respondents have had with Los Angeles Policemen. The statements in the multiple-choice section of the questionnaire were taken from those developed by Professor Parratt, ${ }^{2}$ and validated under his direction.

Selection of the Sample: A large sample was selected-3,100 cases-so as to overcome any differential in external factors; that is, press releases, etc., taking place during the period covered by the survey.

Stratification of the sample, so as to obtain a true cross section of the citizens of Los Angeles, was accomplished by obtaining the cooperation of a large number of persons in varied groups; and selecting the sample from among their responses, using machine methods and basing the stratification upon data obtained from Eshref Shevky's and Marilyn Williams' work, The Social Areas of Los Angeles. ${ }^{3}$

Tabulation of the Data: A method of coding the free-answers was devised, and results of the written responses, together with biographical information and answers to the multiple-choice questions for each respondent, were placed on punched cards. Tabulations of the punched cards bring to light many facts which should prove of interest and value to police administrators and students of

\footnotetext{
2 Parratt, Spencer D.: A Scale to Measure Effectiveness of Police Functioning. $J$. Crim. Law and Criminol., January-February, 1938, pp. 739-56.

${ }^{3}$ Shevky, Ehref and Williams, Marilyn: The Social Areas of Los Angeles. Berkeley, University of California Press, 1949, $172 \mathrm{pp}$.
} 
police administration, as well as persons concerned with municipal administration and public relations in general.

\section{OVER-ALL PICTURE}

It would appear that, generally, the citizens of Los Angeles feel that they have a very good police department. The ratings of the respondents are highest for those traits, or modes of conduct, which can be physically seen and measured; that is, Appearance, Physical Condition, and Education; and lowest for the more intangible traits such as Honesty, Professional Interest, Basis of Selection, and Influence of Politics, The "Do Not Know" responses were, generally, lowest for those traits rated highest-and highest for the traits rated lowest. This is significant, for it indicates that the more people actually know about their policemen, the better they like them.

About one fourth of all respondents admit that they do not know how to rate policemen as regards the more intangible traits. It is somewhat amazing, for instance, to discover that in a city like Los Angeles, where the civil service system is thoroughly entrenched and scrupulously administered, 27 per cent of the citizens do not know whether policemen are selected on the basis of merit or not.

\section{FREE-ANSWER RESPONSES}

When the respondents were given an opportunity to tell in their own words about personal contacts they had had with policemen, they reported almost as many favorable as unfavorable experiences. Of all the free-answers, $43 \cdot 4$ per cent refer to contacts with motorcycle officers and officers in traffic cars. Of these, 48.9 per cent are favorable, and $5^{1.1}$ per cent are unfavorable. Of the favorable comments regarding traffic, 29.7 per cent deal with the issuance of traffic citations; whereas, $49 \cdot 7$ per cent of the unfavorable comments concerning traffic have to do with the issuance of traffic citations. Next to traffic, uniformed motor patrol elicited the most comments-both favorable and unfavorable. Of the comments in this field, 32.4 per cent are approving and 67.6 per cent are disapproving.

Uniformed foot patrol brought out only one third as many comments as did motor patrol, and only one-twelfth as many as 


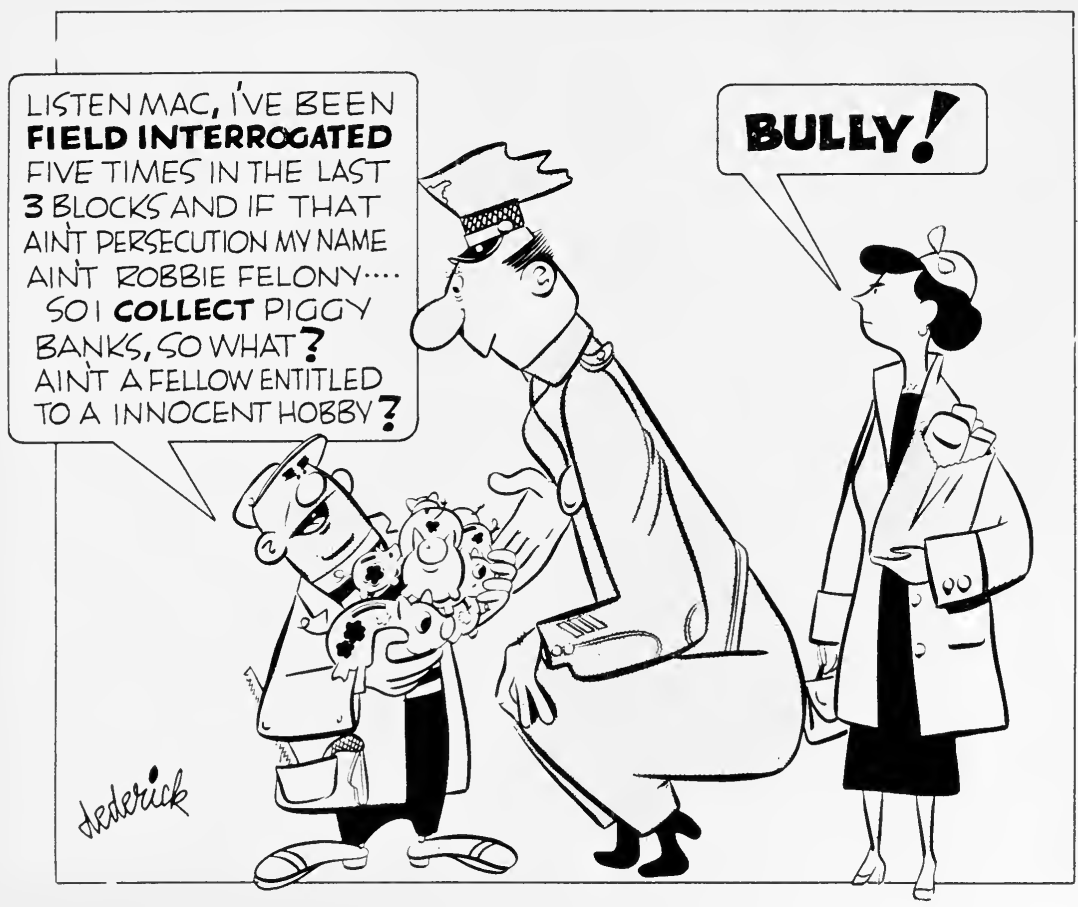

Figure 38. Field Intfrogations

Field interrogations or "shakedowns" are essential to efficient police work. Because their very nature makes them a source of resentment, however, they must be handled as tactfully as possible.

did traffic. The greatest number of unfavorable responses deal with the making of field interrogations. Detective operations and juvenile activities each induced about as many comments as did uniformed foot patrol.

Among the comments made in the free-answers, over one third refer to attitudes of police officers- 54.6 per cent being favorable and 45.4 per cent unfavorable. Among the favorable comments, $5^{8.8}$ per cent refer to officers' courtesy; and among the unfavorable comments, 20.9 per cent refer to discourtesy, 17.9 per cent to prejudice, and 16.1 per cent to overbearing or superior attitudes.

The most frequently-occurring statements of respondents concern actions by policemen. Of these, 34.6 per cent are favorable, and 65.4 are unfavorable. Most favorable comments mention com- 


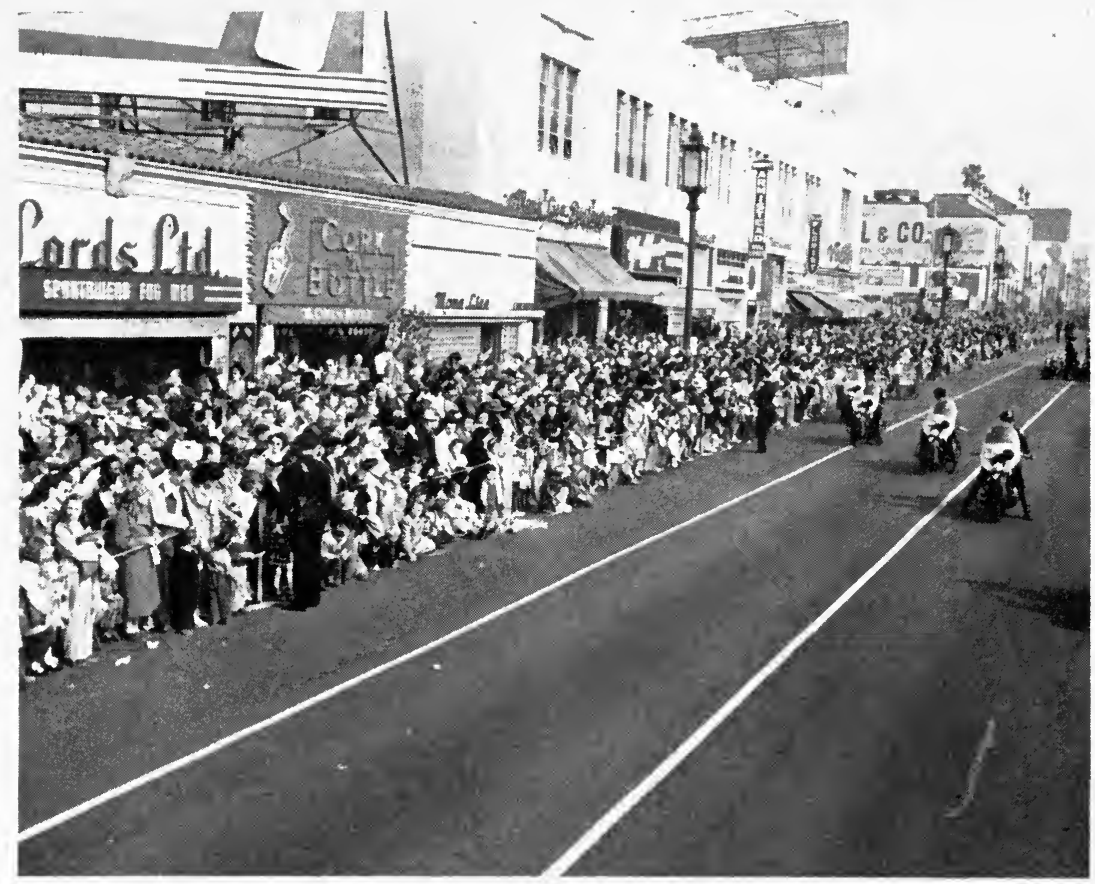

Figure 39. "March of Dimes" Parade, Wilshire Blvid, Los Avgilis

Parades offer great opportunities for favorable contacts between the police and the public. (Note the officers facing the crowed and not the parate.)

petency and helpfulness; whereas, most unfavorable comments refer to unjustified tickets or arrests, rough treatment, inconsistency of traffic enforcement, or unjustified questioning.

\section{AGE GROUPS}

The older citizens of Los Angeles-that is, those 55 years and over-are definitely more favorably inclined toward their police department than are the other age groups. This is shown by their over-all evaluation, as well as by their selection among the alternatives for each of the other traits. Next in strength of approval is the 44 to 55 year age group. Concerning many items, the expressed attitudes of the youngest group-that is, 17 and under-are more favorable than those of all respondents. This is particularly true of the traits of Honesty, Training, Selection, Equipment, Crime Prevention, Juvenile Delinquency, Investiga- 


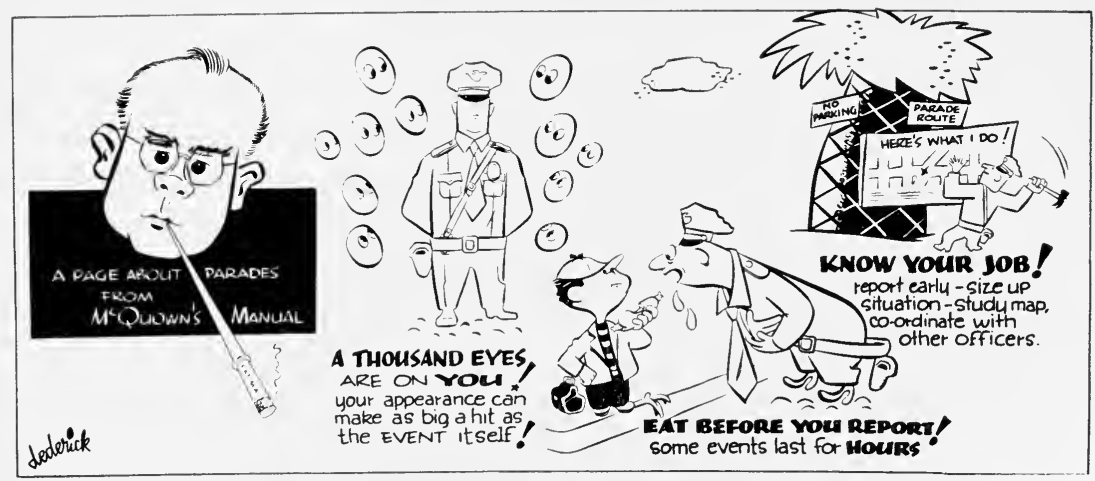

Figure fo. A Thousand Eyes Are on You

tion and Apprehension, Treatment of Suspects, and Supervision. The boys and girls expressed a strong belief that Los Angeles Policemen are usually watchful to prevent Juvenile Delinquency.

The only item which is marked by the youngsters less favorably than by all respondents is Attitudes of Boys and Girls. This is significant, for they should be in a position to know how they feel personally. The three age groups which are least enthusiastic concerning policemen are the 18 to 24 , the 25 to 34 , and the 35 to 44 year groups.

\section{SEX}

In Los Angeles, the males look upon the police more favorably than do the females. This is true of the Over-all Evaluation, as well as almost all of the specific traits. The only traits for which the females rate the policemen higher than do the males are Appearance, and Physical Condition.

The percentage of females who admit they do not know how to rate policemen is, in every case, higher than the males-in most cases, about twice as high.

\section{NATIONALITY}

That Los Angeles Negroes take a dimmer view of their police department than do other ethnic groups is clearly indicated by this survey. The Mexicans are more favorably inclined, but still not as favorably as are the "White" respondents. There are a few interesting exceptions to this general rule. For instance, a higher 
percentage of Mexicans than other nationalities believe that Los Angeles Policemen are usually men of high school education or higher, and that they are highly trained in modern police methods. Of the various nationality groups, the Mexicans appear most certain, and the "White" respondents least certain, as to how the policemen should be rated.

\section{MARITAL STATUS}

Material status does not appear to be a significant factor in influencing attitudes toward the police. It any one marital classification is more favorably inclined toward the police, it is the married group; if any one classification is less favorably inclined, it is the divorcees. The most significant factor appears in the "Do Not Know" column. For every trait, the widowed respondents state they do not know how to rate Los Angeles Policemen far more frequently than do other respondents. This, however, may be due to a differential in age.

\section{EDUCATION}

Although variation in attitudes toward the police among the groups with different educational levels is not great, there is a definite trend among the respondents with the least schooling to look most favorably upon their policemen; and for those with the most schooling to look upon them with the least approval. The most favorably inclined group consists of the respondents who have completed the eighth grade or less. The more favorable attitudes of the lowest educational group are closely approximated by the respondents who have completed the ninth, tenth, and eleventh grades, and frequently by the high school graduates. The college graduates, and those with five or more years of college training, rate policemen in the top bracket far less frequently than do respondents with fewer years of formal education.

\section{LENGTH OF RESIDENCE}

The newest and the oldest residents vie with one another to rate Los Angeles Policemen most favorably. The respondents who have resided in the city 10 years and over rate their policemen in the 
top bracket more often than do other respondents for seven traits; whereas, the respondents who have lived in the city for less than one year place the Los Angeles Policemen in the top bracket more often than do other respondents for 12 traits. It is possible that the slightly more favorable attitudes of the newest respondents may be due, in part, to the fact that they were not exposed to unfavorable newspaper publicity arising from an alleged case of "police corruption" occurring a year prior to this survey.

\section{OCCUPATION}

Undoubtedly, one of the most significant factors in determining public attitudes toward the police, as revealed by this survey, is occupation. Excluding the "Public Servants"-who, to a large extent, are policemen and, consequently, very favorably inclined toward the police department-the occupational group most favorably inclined is that of Unskilled Labor. These respondents expressed more confidence in the Honesty, Courtesy, and Training of their policemen than did the Public Servants themselves. The attitudes of Skilled Laborers are found in most cases to be slightly less favorable than those of Public Servants and Unskilled Laborers, but more favorable than all other respondents. The transportation workers, consisting of taxi cab, bus, truck, and street car operators, etc., who have frequent contact with the police, consistently rate them higher than do other Skilled Laborers and other respondents in general.

Rating policemen lowest for most traits are Professionals, Students, and Housewives. The executives consistently rate the police much higher than do other professional groups. The entertainers consistently rate nuch lower. Attorneys rated lower than did the other professional groups for Courtesy, Training, Basis of Selection, Juvenile Delinquency, Minority Groups, and Protection of Innocent. They ran a close second in rating policemen low in Honesty. Doctors and dentists rated lower than all other Professionals for Physical Condition; and higher than all others for Protection of Innocent. Although school teachers rated lower than all other professional groups for only Departmental Discipline, their expressed opinions are consistently lower than the average 


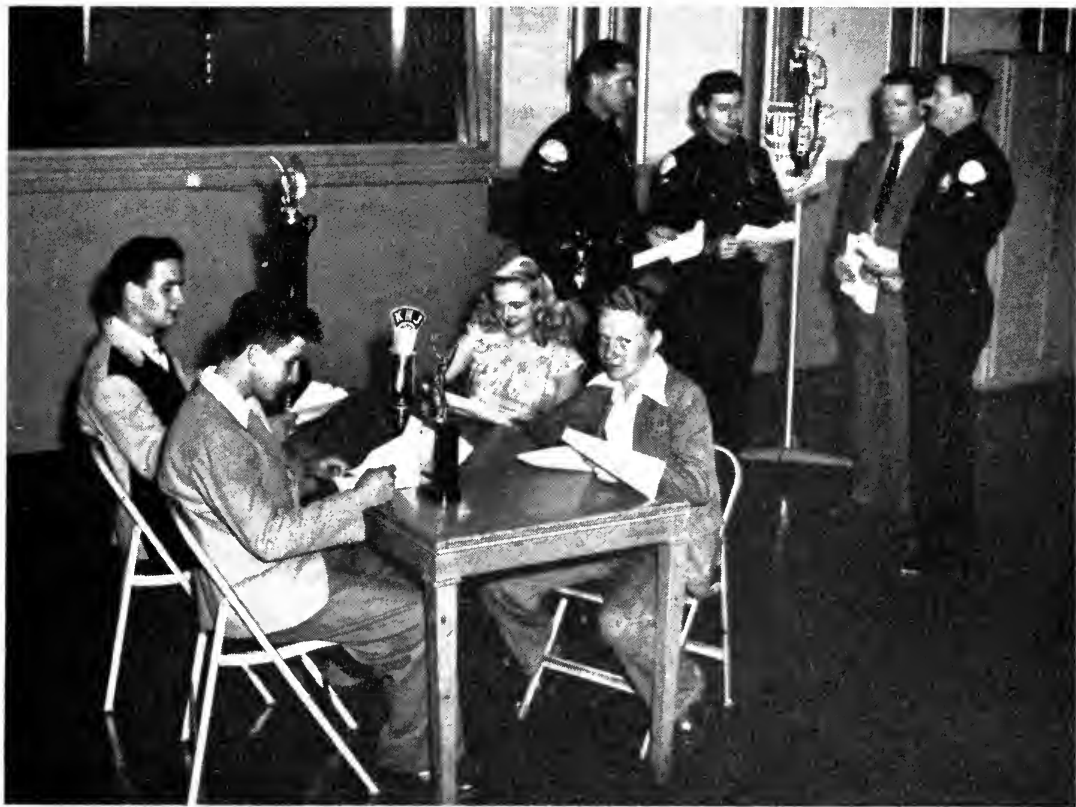

Figure 4 HA Ald 41 B. CoNveying the Facts

Above, high school students and policemen participate in a radio formm on trafic problems. Below, television cameras bring traffic problems and the police into citizens' homes. Newspapers, talks, and other mectia are also avaliable for the purpose of (reating favorable contacts.)

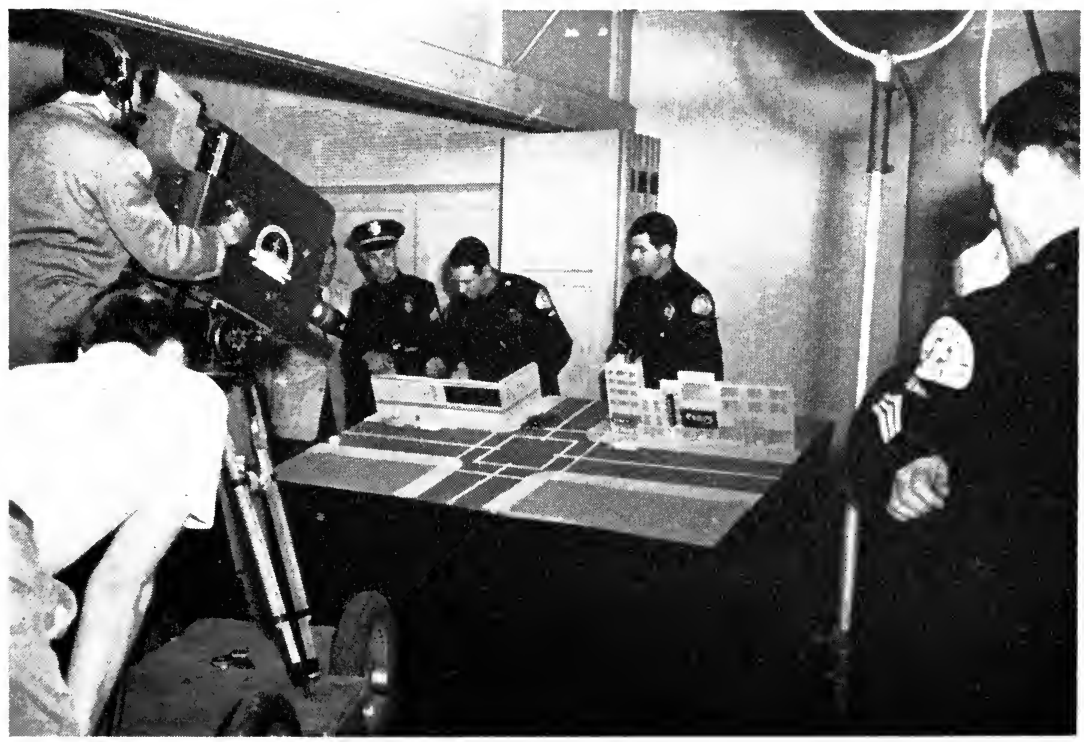


for all Professionals, and materially lower than the average for all respondents.

Housewives rated their policemen lower than did all other respondents for seven of the 22 traits. Of all the occupational groups, the Housewives admit most often that they do not know how to rate Los Angeles Policemen. As unfavorable as the ratings of Housewives are, they are not nearly as unfavorable as the ratings of female school teachers, who rated particularly low for the traits of Honesty, Courtesy, and Discipline.

\section{GUIDEPOSTS TO SATISFACTORY PUBLIC RELATIONS}

As a result of this study, the following facts stand out clearly as guideposts to more satisfactory relations between the police and the public:

1. There is an appalling lack of information on the part of the public concerning the caliber of their police and the conditions under which they operate.

2. Public attitudes-both good and bad-toward the police exist in direct proportion to the number of contacts between the police and the public.

a. Non-punitive contacts with the public tend to create more favorable attitudes toward the police than do punitive contacts.

b. Lacking adequate non-punitive contacts with the police, a citizen is more apt to be influenced by a single adverse contact, or by unfavorable publicity concerning the actions of an individual officer in a specific case.

3. The strongest supporters of the police are the skilled and unskilled laborers-and not the professional and other higherincome groups, as generally believed.

a. Adequate and courteous police service must be rendered to all citizens regardless of economic or social position in the community.

b. Public information efforts and non-punitive contacts should be designed to reach citizens in the higher-income brackets. 


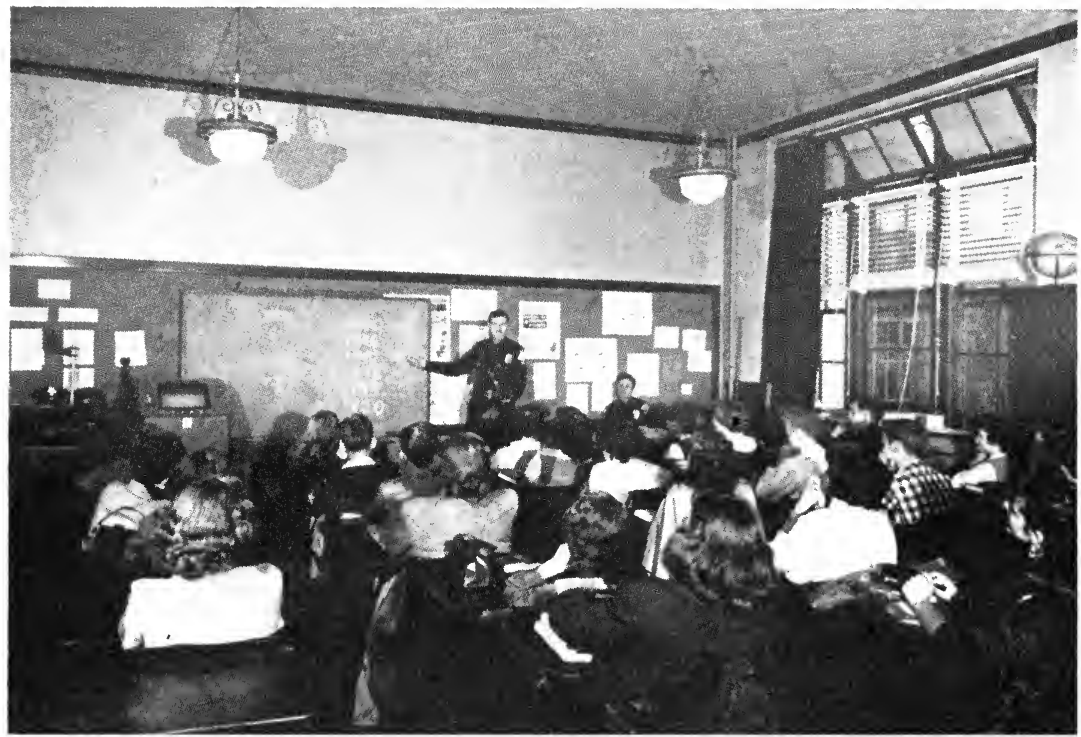

Figitre 12 A aNo 12 B. Contacting Sitdexts

Above, a policeman talks to a high school class regarding traflic problems. Below, a group of roung boys on a conducted tour of the police department.

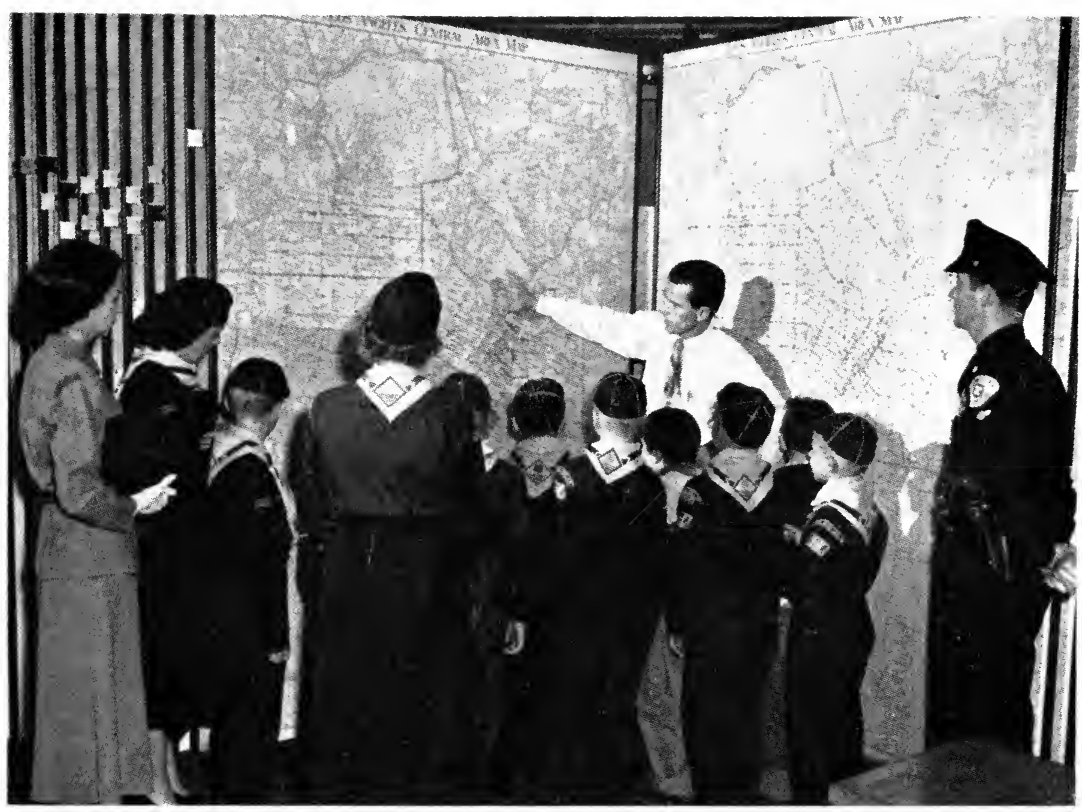


4. There is a tendency on the part of people with the least formal education to look most favorably upon the police; and for those with the most formal education to look upon the police with the least favor.

a. A searching inquiry must be made to determine the quality of police service actually being performed.

b. Measures should be adopted to truthfully and convincingly convey these facts to the better-educated citizens.

5. Current relations between the police and minority groups leave much to be desired.

a. Recruit and in-service training in race relations should be improved and intensified.

b. Actual performance of police in dealing with members of minority groups must be critically scrutinized; and improved, if improvement is indicated.

c. The police should publicly cooperate whenever possible in movements to advance understanding and harmony between persons of all races and creeds.

6. Women, particularly, are lacking in information regarding the true performance of their police.

a. This is especially true of school teachers and housewives.

b. Efforts must be made to reach women through every means available. Parent Teachers Associations and school children are logical avenues of information.

7. Students are inclined to look upon the police with less than average enthusiasm.

a. This is especially true at the college level.

b. As many favorable non-punitive contacts as possible should be arranged between the police and students and their instructors.

8. To be discouraged in police by adequate selection, training, and supervision are:

a. Attitudes of discourtesy, prejudice, superiority, and indifference.

b. Actions of unjustified arrests or citations, rough treatment, and inconsistency of traffic law enforcement.

9. To be encouraged in police by adequate selection, training, and supervision are: 
a. Attitudes of courtesy, cooperation, sympathy, helpfulness, and tolerance.

b. Actions of honesty, competency, promptness, and assistance of all kinds.

10. The things the public most need convincing of are that their policemen:

a. Have a high professional interest in their work.

b. Are selected for personal merit and ability.

c. Operate under excellent discipline.

d. Apprehend criminals indiscriminately, without regard for pressure brought by influential persons.

e. Operate independently from newspaper publicity.

f. Usually apprehend criminals in difficult cases.

g. Respect the Constitutional Rights of suspected criminals.

h. Are usually fair in dealing with minority groups.

i. Are careful not to arrest innocent persons.

j. Are directed by competent supervisors and top administrators. 


\section{BIBLIOGRAPHY}

\section{BOOKS AND PAMPHLETS}

Anlow, Elijah: Policemen and People. Boston, Norwood Press, 1947, $89 \mathrm{pp}$.

B'nai B'rith, Antr-Defanation League: A Study of Police Training Programs in Minority Relations. Southern California Regional Office, 1950. (Mimeographed), v. p.

Blankenship, Albert B.: How to Conduct Consumer and Opinion Research. New York, Harper, 1946, $314 \mathrm{pp}$.

Bonger, Wimlian A.: Race and Crime. New York, Columbia Univ. Press, 1943, $131 \mathrm{Pp}$.

Brown, Eari: Whiy Race Riots. New York, Public Affairs Committee, Incorporated, 1944, $31 \mathrm{pp}$.

Brynes, Ascufr: Government Against the People. New York, Dodd, $1946,265 \mathrm{PP}$.

Ciallan, G. and Strplienson, R.: Police Methods for Today and Tomorrow. Newark, New Jersey, Duncan Press, 1939, 361 pp.

Cantor, Nathaniel F.: Crime, Criminals and Criminal Justice. New York, Holt, 1932, 469 pp.

Chander, George F.: The Policeman's Art. New York, Funk, 1922, $212 \mathrm{pp}$.

Fisher, Lroyd H.: The Problem of V'iolence. San Francisco, American Council of Race Relations, 1946, 20 pp.

Floherty, John J.: Behind the Siluer Shield. New York, Lippincott, $1948,195 \mathrm{pp}$.

Fosmick, Raymond B.: American Police Systems. New York, Century, 1920, $408 \mathrm{pp}$.

Fospick, Raymond B.: European Police Systems. New York, Century, $1915,442 \mathrm{pp}$.

Frank, Elizabeth R.: Background for Planning. Los Angeles Research Department, Welfare Council of Metropolitan Los Angeles, 1949, $125 \mathrm{pp}$.

Gerletti, John D.: A Problem Analysis of the Work of the Junenile Officer for the Purpose of Developing Materials for an In-Service Training Program. (A Doctoral Dissertation). University of Southern California, 1949 . 
Gillespie, William: The Citizen's Friend. London, Longmans, 1944, 33 Pp.

Graper, Elmer D.: American Police Administration. New York, Macmillan, 1921, 357 pp.

Hanson, Earl and Becketr, Paul: Los Angeles: Its People and Its Homes. Los Angeles, The Haynes Foundation, 1944, 207 pp.

Harrison, Richard: Whitehall I2I2: The Story of the Police of London. New York, Jarrolds, 1948, 240 Pp.

Holcomb, Richard L.: The Police and the Public. Iowa City Institute of Public Affairs. State University of Iowa, 1950, $3^{6} \mathrm{pp}$.

Hopkins, Ernest Jerome: Our Lawless Police. New York, Viking, 1931, 379 pp.

Howard, Pendeton: Criminal Justice in England. New York, Macmillan, 1931, 434 Pp.

Kavanaugh, Thomas S. J.: Minute Police Talks. Boston, Williams Book Store, 1938, $196 \mathrm{pp}$.

Kunchecky, Joseph T.: Police Action in Minority Problems. New York, Freedom House, $1946,15 \mathrm{pp}$.

Lavine, Emanuel H.: Cheeze It-The Cops. New York, Vanguard, 1936, 303 pp.

Lavine, Emanuei. H.: The Third Degree. New York, Garden City Pub., 1930, 248 pp.

Lee, Alfred M.: Race Riots Aren't Necessary. Chicago, American Council of Race Relations, 1945, 29 Pp.

Lee, Alfred M. and Humphrey, Norman D.: Race Riot. New York, Dryden, 1943, 143 pp.

Leonari, V. A.: Police Organization and Management. Brooklyn, Foundation Press, 1951, 507 pp.

Leyson, Burr W.: Fighting Crime. New York, Dutton, 1948, 193 pp. Lohman, Joseph D.: Police and Minority Groups. Chicago, Chicago Park Press, 1947, 133 pp.

McEntire, Davis and Powers, Robert B.: A Guide to Race Relations for Police Officers. Sacramento, California, Department of Justice, State of California, 1946, $3^{8} \mathrm{pp}$.

Millspaugh, Arthur C.: Local Democracy and Crime Control. Washington, D.C., The Brankings Institution, 1936, 263 pp.

National Commission of Law Observance an1) Enforcement: Report on Lawlessness in Law Enforcement. Washington, United States Government Printing Office, 1931, 347 pp.

National Commission on Law Observance and Enforcement: $R e$ - 
port on Police. Washington, United States Government Printing Office, 1931, $140 \mathrm{pp}$.

Olander, Oscar G.: Police Courtesy. Lansing, Michigan, F. DeKline Company, 1937, 47 pp.

Orlansky, Harold: The Harlem Riot. New York, Social Analysis, 1943, $29 \mathrm{pp}$.

Parten, Mildred: Surveys, Polls, and Samples: Practical Procedures. New York, Harper, 1950, 624 pp.

Perkins, Rollin M.: Elements of Police Science. Chicago, The Foundation Press, 1942, $65^{1} \mathrm{pp}$.

Pickert, Heinrich: Your Security. Detroit, Detroit Police Department, 1937, 15 pp.

Pound, Roscoe: Criminal Justice in America. New York, Holt, 1930, 226 pp.

Reed, Leroy B.: Human Wolves. Kansas City, Brown, White, Lowell Press, 1946, 419 pp.

Reith, Chart.es: British Police and the Democratic Ideal. New York, Oxford, 1943, 280 pp.

Rogers, Lindsay: The Pollsters. New York, Knopf, 1949, 239 pp.

Seagle, William: There Ought To Be A Law. New York, Macarley, $1933,15^{8} \mathrm{pp}$.

Shehan, James J.: "What Policemen Should Know." The Police Journal. New York. 1935, 307 pp.

Shevky, Eshref and Lewin, Molly: Your Neighborhood. Los Angeles, The Haynes Foundation, 1949, 40 pp.

Shevky, Eshref and Williams, Marilyn: The Social Areas of Los Angeles. Berkeley, University of California Press, 1949, $172 \mathrm{pp}$.

Skehan, James J. and Basuino, Francis M.: What Policemen Should Know. New York, Basuino, 1934, 387 pp.

Smith, Bruce: Police Systems in the United States. New York, Harper, 1940, 384 pp.

The American Soldier. United States Army, Research Branch, Information and Education Division. Princeton, New Jersey. Princeton University Press, 1949. Vols. I, II, III, IV.

The Public's Attitude on Traffic Safety. Opinion Research Corporation. Princeton, New Jersey, 1946, $79 \mathrm{pp}$.

Tomkin, M.: Police and Public. London, John Long Limited, 1936, $286 \mathrm{pp}$.

Vollmer, August: The Criminal. New York, Foundation Press, 1949, $4^{62} \mathrm{pp}$. 
Vollmer, August: The Police and Modern Society. Berkeley, California, University of Berkeley Press, 1936, 253 pp.

Vollmer, August and Parker, Alfred E.: Crime and the State Police. Berkeley, California, University of California Press, 1935, $226 \mathrm{pp}$. Weckler, J. E. and Hall, Theo. E.: The Police and Minority Groups. Chicago, International City Managers Association, 1944, 20 pp.

Wilson, O. W.: Police Administration. New York. McGraw-Hill, 1950, $54^{\circ} \mathrm{pp}$.

Woods, Arthur: Policeman and Public. New Haven, Yale, 1919, 178 pp.

Wright, S. Fowler: Police and Public. London, Fowler Wright, Ltd., 1929, 140 pp.

\section{ARTICLES}

Allen, Eric W.: The Public Relations Problem of the Police. The Commonwealth Review. University of Oregon, 2I:212-21, November, 1939 .

Allman, J. P.: The Police and the Public. Proceedings of the FortySecond Annual Convention of the International Association of Chiefs of Police, 1935 , pp. 87-9.

Almond, J. Lindsay, Jr.: The Police Officer: His Relationship to the Public. Virginia Municipal Review, 27:9-11, January, $195^{\circ}$.

America Speaks. (A News Release). American Institute of Public Opinion, January 2o, 1938.

Avery, Robert S.: Civil Service and Citizen Opinion. National Municipal Review, 3o:412-17, July, 1941.

Bailes, H. H.: Relationship Between Police and Press. Michigan Police Journal, I7:8, July-August, 1948.

BAIN, READ: Policemen and Children. Sociological and Social Research, 23:417-23, July, 1949 .

Barron, William A.: A Crime Prevention Program in a Police Agency. Pacific Coast International Law Enforcement News, I6:10-12, August, 1949 .

BeAcher, W. H.: Marks of a Good Policeman. The Police Journal, London, 26:8, March-April, 1940.

Bellamy, Paul: Why Print Crime News. Proceedings of the Attorney General's Conference on Grime. Washington, D.C. United States Government Printing Office, 1934.

Bellman, Arthur: A Police Service Rating Scale. Journal of Criminal Law and Criminology., 26:74-114, May, 1935. 
Beyer, William C.: The Policeman's Hire. Annals of the American Academy of Political and Social Science, If6:135-47, 1929.

Beyle, Herman C. and Parratt, Spencer D.: Measuring the Severity of the Third Degree. The Journal of Griminal Law and Criminology, $24: 485$, July-August, 1933 .

Bingery, Malcolm W.: The Responsibility of Newspapers in Law Enforcement. Proceedings of the Fortieth Annual Convention of the International Association of Chief of Police, 1933, pp. 101-10.

Biscailuz, Eugene W.: Public Relations and Auxiliary Units. Pacific Coast International Law Enforcement News, If:17-24, December, 1947 .

Bretz, W. D.: Public Relations of Police Organizations. F.B.I. Bulletin, $8: 25$, February, 1939 .

Bricke, Nestor N.: Police and Political Activities. Political Yearbook of the International Association of Chiefs of Police, 1940, pp. 38-39.

Browneli, Frederick G.: It Could Happen to You: Overzealous Police. American Magazine, I47:24-5, May, 1949.

Carson, Joseph K.: Police and Public Attitudes. Yearbook of the International Association of Chiefs of Police, 1937-38, pp. 16-17.

Carter, J. F. C.: The Press and the Police. Police Journal, London, 3:509-518, October, 1930.

Carter, M. J.: Public Support for Police. Police Journal, New York, 35:19, 22-23, September-October, 1949.

Chartes, Biron: Public and Police, A Magistrate's View. Police Journal, England, 3:164-75, April, $193^{\circ}$.

Cimt, Raymond E.: Police, Press, and Public Relations. The Journal of Criminal Law and Criminology, 39:667-74, January-February, 1949 .

Cops Win Friends and Influence Young Drivers. Police Journal, New York, 36:20, March-April, 1951.

Courtesy. F.B.I. Law Enforcernent Bulletin, 8:33-36, November 1, 1939 .

Cunningham, Frank H.: Public Relations. Unpublished lecture to policemen, Los Angeles Police Department. Los Angeles, 1945.

Cuttrell, George: Crime Prevention Unit. Unpublished paper, Los Angeles Police Department, Public Relations Section. Los Angeles, 1949 .

Delemanty, M. J.: The Police Department and Public Relations. Police Journal, 35:9, September-October, 1949.

Delemanty, M. J.: The Police Department and Public Relations. 
Pacific Coast International Law Enforcement News, 17:3-9, February, 1950.

DeSilva, Harry R.: Strategy in Handling People. New England Traffic Officers' Training School. Cambridge, Massachusetts, August, 1937. Drew, J. E.: The Businessman's View of Law Enforcement. The Police Yearbook, 1940, p. 219.

Ellingston, J. R.: New Police Methods With Children. American City, 64:91-93, January, 1949.

Emerson, F. W.: Law Enforcement Agencies and Public Relations. Unpublished paper, Public Relations Section, Ninth Annual Institute of Government, The University of Southern California, Los Angeles, 1937 .

Fawcett, Thomas: What Kind of Police Service Do We Want? Police Journal, London, 19:208-18, July, 1946.

Frahm, Fred W.: Meeting the Public. Michigan Police Journal, 8:4, April, 1939 .

Gocke, B. W.: Morale in a Police Department. Journal of Criminal Law and Criminology, 36:215-19, September-October, 1945 .

Halsey, Maxwell: Building Support for Police Departments. New England Traffic Officers Training School. Cambridge, Massachusetts. August, 1937, p. 18.

Halsey, Maxwell: Public Relations or Building Support for Police Departments. The Second Annual New England Traffic Officers' Training School. Cambridge, Massachusetts. International Association of Chiefs of Police, 1937.

Handling Racial Conflicts. American City, 62:17, October, 1947.

Haymond, Frank C.: Public Relations Between Courts and Law Enforcement Officers and the Public. The Journal of Criminal Law and Criminology, 38:409-15, November-December, 1947.

Highfill, Robert D.: The Effects of News of Crime and Scandal Upon Public Opinion. Journal of the Institute of Criminal Law and Criminology, 17:40-103, May, 1926.

Hohmann, Arthur: Police Courtesy. Proceedings of Igth Annual Convention of Peace Officers Association of the State of California. Santa Cruz, California, 1939, pp. 6-9.

Hollingsworth, Dan: Public Support for Police. An unpublished address made at the National Safety Congress. Chicago, Illinois, 1935 .

Keenan, J. B.: Establishing Public Opinion in the Fight Against Crime. American Bar Association Reports, 57:307-14, 1934. 
Kelso, John: Courtesy Courses for Cops. Michigan Political Journal, I7:14, July-August, 1948.

Kooken, D. L.: Ethics in Police Service. Journal of Criminal Law and Criminology, 38:61-74, May-August, 1947.

McEntire, Davis and Weckler, J. E.: Roll of Police in Controlling Groups Prejudice. Annals of the American Academy of Political and Social Science, 244:82-9o, March, $194^{6 .}$

McKnight, Felix R.: Mutual Aid for Police and Press. Police Chiefs News Letter, 16:40, October, 1949.

Maddox, C.: Twenty-Two Don'ts for the Peace Officer in the Courtroom. F.B.I. Law Enforcement Bulletin, Io:32, October, 1941.

Maslow, Will: Law and Race Relations. Annals of the American Academy of Political and Social Science, 244:75-82, March, 1946.

Massen, John B.: Selling Police Work to the Public. Public Management. Chicago, 23:195-98, May, 1941.

Merriam, Charles E.: Police and Public. Proceedings of the Fortieth Annual Convention of the International Association of Chiefs of Police, 1933, pp. 96-100.

Merriam, Charles E.: The Police, Crime, and Politics. Annals of the American Academy of Political and Social Science, I46:115-21, 1929 .

Miller, Justin: Public Opinion and Crime. South Atlantic Quarterly, April, 1931, pp. 141-54.

Mingle, G.: Police Personnel Evaluation and Development. Journal of Criminal Law and Criminology, 36:277-89, November-December, 1945 .

Morris, G. S.: Want a Policeman? Literary Digest, I24:28. December 25,1927 .

Murray, J. F.: Public Relations in Law Enforcement. F.B.I. Law Enforcement News, 20:19-21, May, 1951.

My Grouse Against the Police. Saturday Review, ${ }_{4} 6: 809$, December 15, 1928.

Negligence of Police Officers. Law Journal, 82:96, August 8, $193^{6 .}$

O’Brien, William P.: Police and Public Relations. The Police Journal, 35:3-4, 29, January-February, $195^{\circ}$.

Olander, Oscar G.: Police Courtesy. Michigan Police Journal, 8:9, May, 1939 .

Olivier, Warner: Cops Don't Have to be Brutal. Saturday Evening Post, 219:20, December 28, 1946.

Palmer, G.: On Patrol with Crime Proofers. (What merchants and 
filling station operators are told to do.) Reader's Digest, 33:93-6, August, 1938.

Parker, William H.: History of Police. Unpublished paper, Los Angeles Police Department. Los Angeles, 1946, $6 \mathrm{pp}$.

Parker, Willian H.: The Police and the Public. The Los Angeles Daily Journal. (A speech, recorded and transcribed.) March $7,195^{1}$. Parratt, Spencer D.: A Critique of the Bellman Police Service Rating Scale. Journal of Criminal Law and Criminology, 27:895-908, MarchApril, 1937.

Parratt, Spencer D.: A Scale to Measure Effectiveness of Police Functioning. Journal of Criminal Law and Criminology, 28:739-56, January-February, 1938.

Parratt, Spencer D.: How Effective Is a Police Department? Annals of the American Academy of Political and Social Science, 199:15364, September, $193^{8}$, pp. ${ }_{15} 3^{-64}$.

Peterson, V. W.: Let's Prevent a New Crime Wave Before It Starts. Bankers' Monthly, 6o:349-5, August, 1943.

Police and Public. New Statesman and Nation, Ir:491-2, March 28, 1936.

Police and Public Enjoy Mutual Confidence in Britain. Canadian Police Bulletin, 11-12, September, $195^{\circ}$.

Police and the Press. Spectator, I6o:666, April ${ }_{15}, 193^{8 .}$

Policemen Who Do Not Patrol. Journal of Criminal Law and Criminology, $31: 616$, January, 1941.

Police Neutrality. Nation, 150:239, February 17, 1940.

Public Attitudes Toward Postwar German Police. I. General Appraisals. Report No. 166 (Mimeographed), 8 pp. Bad Nauheim, Germany. Opinion Surveys Branch, Information Services Division, Office of the Military Government of the United States, APO 807 .

Public Attitudes Toward Postwar German Police. II. Awareness of Civil Rights Versus Police Powers. Report No. 167 (Mimeographed) 9 pp. Bad Nauheim, Germany. Opinion Surveys Branch, Information Services Division, Office of the Military Government of the United States, APO 807.

Public Relations Campaign. Canadian Police Gazette, 25:32, April, 1950.

Quinn, Willinm J.: Courtesy. Police and Peace Officers' Journal, San Francisco. December, 1938, pp. $5^{-6}$.

Reimer, W. J.: The Public and the Police. Yearbook of the International Association of Chiefs of Police, 1938-39, pp. 167-71. 
Reith, C.: Preventive Principle of Police. Journal of Criminal Law and Criminology, 34:206-9, September-October, 1943.

Rice, T. S.: The Importance of Publishing Crime News. Panel, 9:31, May, 1931.

Scripps, William J.: Press, Police, and Traffic. Police Chiefs' News Letter, I6:26, October, 1949.

Sheene, G. H.: Police Training for Recruits and In-Service Personnel. Journal of Criminal Law and Criminology, 35:281-96, NovemberDecember, 1944 .

Simon, Richard: Roll Call Training Program of Los Angeles Police Department. Journal of Criminal Law and Criminology, 40:507-518, November-December, 1949.

Sмrth, E. L.: Police and Law-Abiding Citizens Versus Crime. American Police Review, 3:4, March-April, 1939.

Smyth, Lov: How the Public Sees Us as Police Executives and Police Officers. Police Chiefs' News Letter, I3: June-November, $194^{6}$.

Stone, Donald: The Control and Discipline of Police Forces. Annals of the American Academy of Political and Social Science, 146:63-74, 1929 .

Study the Picture-It Tells a Story. Pacific Coast International Law Enforcement News, $17: 1$, March, $195^{\circ}$.

Sullivan, T. P.: Police and Public Relations. Pacific Coast International Law Enforcement News, If:3-4, December, 1947.

Thomas, J. L.: Police and the Press. Canadian Police Gazette, 23:3-9, 12-17, January, 1949.

Turner, C. E.: Publicity as an Aid to Recruiting. Police Journal, London, 2o:284-92, October, 1947.

Vaughan, Donald G.: Public Opinion and Road Safety. The Police Journal, 22:15-20, December, 1935 .

Wilson, Harold: The Police and Public Opinion. Police, 13-13. Chicago, 7:8-23, October, 1932.

Wilson, O. W.: Public Relations. Manual of Instruction, Kansas Police School. Topeka, Kansas. Kansas State Printing Plant, 1938, pp. 152-3. Wittels, David G.: Why Cops Turn Crooked. Saturday Evening Post, $221: 26-7$, April 23, 1949.

Young, Donald: Police Journalism in the United States. Annals of the American Academy of Political and Social Science, 146:128-35, 1929. 



\section{INDEX}

A

Accidents, 22 (see Traffic accidents)

Activities

detective operations, 53

juvenile, 53

miscellaneous functions, 53

traffic, 53

uniformed foot patrol, 53

uniformed motor patrol, 53

Age groups, 63, 100

basis of selection, 63

boys and girls, 77

older citizens, 63

young adults, $i$

Ambiguity index, $3^{6}$

American Federation of Labor, 13

American soldier in World War II, 28

American zone in Germany, 27

Appearance, 41, 46, 50, 62, 63, 65, 7.1, 77, $78,81,82,86,87,90$

Attitude survey, 95

Attitudes, 58

justified, 93

of American soldier in World War II, 28

of boys and girls, 71

of females, 74

of Germans, 26

of males, 71

of Mexicans, 75

of Negroes, 75

of older citizens, 63

of police officers, 99

of "Whites," 75

on traffic safety, 18

weighted total, 19

Auditing, $3^{6}$

Authority, revolt against, 6

\section{B}

Background formation, 30

Basis of selection, $46,5^{\circ}$

controlling factor, $59,77,78,88,9^{\circ}$, 100,103

Biological factors, 63, (see Age groups and sex)
Biographical data, $4^{1}$ (see Personal data)

Black market, 26

Boys and girls, $4^{1}, 5^{0}$

attitudes of, $71,77,78,82,87,90,101$

Bus driver, 87 (see Transportation workers)

\section{C}

"Cafeteria" question, 29

Censorship, 28

Census tracts, 32 (see Postal zones)

Citations, 5l (see Traffic)

Civil rights, 28

of Germans, 25

Civilian defense action, supervising of, $5^{8}$ (see Miscellaneous functions)

Clerical workers, 87

Code number for questionnaire, 45

Commercial workers, 87

Comon-law crimes, 4

Congress of industrial organizations, 43

Contacting suspects (see Detective operations)

Contacts, $9^{8}$

daily, 6

favorable, 12

need for favorable, 95

non-criminal, 4

non-punitive, 105

unfavorable, 42

Courtesy, $41,46,59,61,67,77,78,82,86$, $88,9^{\circ}, 91,103$

Crime prevention, $41,78,100$

Criticisms, unfair, 7

Crowds, handling of, $5^{8}$ (see Miscelaneous functions)

\section{D)}

Data

census, 32

personal, 30

sources, 29

tabulation of, 97

Drunks, handling of, 53 (see Uniformed foot patrol) 


\section{$\mathrm{E}$}

Education, $46,77,78,82,90,102$ college graduates, 79

eighth-grade graduates or less, 79

high school graduates, 79

Enumerators, 12

Equipment and facilities, $41,46,77,7^{8}$, $82,90,100$

\section{F}

Female school teachers, opinions of, $8_{7}$ (see School teachers)

Free-answer response, 29, 41, 98, 99 coding of, 43

favorable, $5^{\circ}$

total of, 50

unfavorable, $5^{\circ}$

Field interrogations, 99

Fines, 28

on-the-spot, 28

$$
\text { G }
$$

Graded response, 29

\section{$\mathrm{H}$}

Honesty, $41,46,65,66,78,82,86,88,9^{1}$, 100,103

Housewives, opinions of, 87, 103, 105

\section{I}

Influence of politics, $41,46,5^{\circ}, 77,78,9^{\circ}$ Influence of press, $11,50,77,78,87,9^{\circ}$ Index of effectiveness, 36

high, 36

medium, 40

low, 40

Information

correspondence, 58

counter, $5^{8}$

telephone, $5^{8}$

Intangible traits, $46,5^{\circ}, 9^{8}$

Investigation and apprehension, 41,78 , $82,88,100$

Investigations, 53 (see Detective operations)

J

Juvenile activities

apprehension of juvenile offenders, 57 contacting suspects, 57

curbing of juvenile delinquency, 57

finding lost children, 57

Juvenile delinquency, $41,77,78,88,9^{\circ}$, 100, 103

opinion of boys and girls, 7

\section{I.}

Laender Constitution, 27

Land Constitution, 27

Law

administration of, 5

defiance of, 5

Law-breakers, 4

Law-observers, 4

Legislatures, 8

Length of residence, 82, 102 (see Sociological factors)

Los Angeles

composition by age, nationality, sex and social areas, 31

composition of population, $3^{1}$

social areas, 31

social rank, 31

urbanization, 31

Los Angeles policemen

actions of, 61

attitudes of, 59

contacts of, 41

favorable impressions of, ${ }_{4} 6$

intangible traits of, $4^{6}$

opinions of, $4^{1}$

over-all evaluation of, $5^{\circ}$

service to public, 41

tangible traits of, $4^{6}$

Lost children, 57 (see Juvenile activities)

\section{M}

Marital status, 102

attitudes of divorced, married, single, and widowed respondents, 78

Method of stratification, 31 (see Stratification)

Mexicans, 101

attitudes of, 75

percentage in Los Angeles, 33

Military, 28

Minority groups, $6,50,59,78,82,88,103$

Miscellaneous functions, 57 
custody of prisoners, $5^{8}$

Deputy auxiliary police force, 57

giving information by correspondence or over counter, $5^{8}$

giving testimony in court, $5^{8}$

handling crowds, $5^{8}$

handling vice situations, $5^{8}$

public relations, 57

report taking, $5^{8}$

telephone conversations, $5^{8}$

Multiple-choice questions, 29, $36,1^{6}$

$\mathrm{N}$

Nationality, 101

attitudes of Mexicans, 75

attitudes of Negroes, 75

attitudes of "Whites," 75

Nazi era, 26

Negroes

attitudes of, 75

percentage in Los Angeles, 33

\section{O}

Occupation, 85 (see Clerical workers, Commercial workers, Female school teachers, Housewives, Professionals, Public servants, Sales people or agents, Skilled laborers, Students, Transportation workers, Unskilled laborers)

Open-question response, 29

Over-all evaluation, $41,50,63,78,86,101$ (see Police department as a whole)

\section{P}

Patrolling (see Uniformed foot patrol, Uniformed motor patrol)

Personal data, $3^{\circ}$,

Physical condition, $41,46,50,63,65,74$, $77,78,81,82,86,90,103$

Police

action, 5

activities and sub-activities, 41, 43

adverse beliefs, 3

authority, 27

constructive action, 7

current standards, 4

decentralized control, 27

efficiency, 7 governmental agency, 6

inefficiency, 8

morale, 7

political life, 27

post-war German, 26

professionalization, 4

testimonies, 8 (see Contacts)

Police department as a whole, $5^{8}$

opinions of

boys and girls, $6_{5}, 7 \mathrm{t}$

college graduates, 79

divorcees, 78

female school teachers, $9^{\circ}$

females, 74

grade school graduates or less, 79

housewives, 90

males, 74

Mexicans, 75

Negroes, 75

older citizens, 63

professionals, 88

public servants, 85

students, 9o

transportation workers, 87

"Whites," 75

widowed respondents, 78

Policemen

attitudes of, 99

duties of, 93

off-duty, 27

strongest supporters, 105 (see Los Angeles policemen)

Police power, 27

Police public relations, $5^{8}$

bad, 59

good, 59 (see Public relations)

Politics (see Influence of politics)

P'ostal zones, 32

Press release, $3^{\circ}$ (see Influence of press)

Prisoners

custody of, $5^{8}$ (see Miscellaneous functions)

Professionals, 87, 88, 103, (see Occupation)

Professional Interest, $41,46,50,78,82$, 86,90

Protection of Innocent, 41, 78, 82, 86, 88, 9o, 103 
Public

cooperation. 7

resistance, 7

Public attitudes

determined by police, 6

device for measuring, 9

factual data, 8

improving, 6

nature of, 8

Public contacts, 3

Public relations, 3

good, 6

importance of, 8

improving, 95

measurement of, 8

methodology for improving, 95

poor, 6

problems of, 3

satisfactory relations, 105

Public servants, 85,103

Publicity, unfavorable, 105

\section{Q}

Questionnaire (see Survey form)

code number, 45

face sheet, 43

face-to-face contacts, 42

tabulated responses, 45

tallying responses, 43

Questions, validation of, 36

"Quota System," 30

\section{$\mathrm{R}$}

Raters, composed of, 36

Recovering property, 53 (see Detective operations)

Report taking, $5^{8}$ (see Miscellaneous functions)

Research Branch, Information and Education Division, U.S. Army, 28

Research methods, 28, 29

Respondents

contacting by group and mail, 42

tallying of replies of, 43

Responses, (see Free-answer response, Graded response)

\section{S}

Sales people or agents, 85,87
Sample

distribution of, 85

selection of, 95

size, 30

stratification of, 95

Scale, auditing of, 36

School teachers, 103, 105 (see Female school teachers)

Search warrant, 27

Sex, 101

attitude of males (see Biological factors)

Skilled laborers, $86,103,10_{5}$

Social rank

factors combined to form, 31

three levels of, 31

Social Science, U.S. Army, 28

Sociological factors, 75 (see Education Length of residence, Marital status, Nationality)

Stratification, method of, 31

Stratified sample, 33

Strcetcar man, 87 (see Transportation worker)

Students, 87, 90, 103

Summary statements, 36

Supervision, $4^{1}, 5^{\circ}$

controlling factor of, $59,78,82,88,101$

Survey form, 10-42

Survey techniques, 29

advantages of, $3^{\circ}$

$\mathrm{T}$

Tangible traits, $46,50,9^{8}$

Taxi driver, 87 (see Transportation worker)

Teamster, $87 \quad$ (see Transportation worker)

Testimony in Court, 57 (see Miscellaneous functions)

Top administration, $41,50,5^{8}, 77,7^{8}$, 82,88

Traffic, $5^{1,}, 9^{8}$

citations, 25, 53

directing uniformed motor patrol, 53

favorable contacts, 59

inconsistency of enforcement, 62

regulation enforcement, 22

safety, 18 
speed traps, 62

violators, 4

Traffic accidents, 22 prevention of, 25

solution of, 19

Training, 62, $77,78,86,88,100,103$ controlling factor of, 59

Traits (see Intangible traits, Tangible traits)

Transportation workers, 87

Treatment of suspects, $41,46,50,62,77$, $78,82,88,101$

Truck driver (see Transportation worker)

\section{U}

Uniformed foot patrol, $9^{8}$

field interrogations, 53

giving information, 53

handling of drunks, 53 making arrests, 53

unfavorable contacts, 59

Uniformed motor patrol, $9^{8}$

answering calls, 53

field interrogations, 53

"shakedowns," 53

"Universe," 30, 33 (see Stratified sample)

Unskilled laborers, $86,109,10_{5}$

Urbanization

measures of, 31

three levels of, 31

\section{V}

Vice, handling of, $5^{8}$ (see Miscellaneous functions)

\section{IV}

"Whites," 101

attitudes of, 75 
, 
This Book

\title{
PUBLIC RELATIONS
}

\author{
AND \\ THE POLICE
}

By

G. Douglas Gourley, M.S.

was set, printed and bound by The Collegiate Press of Menasha, Wisconsin. The engravings were made by The Northwestern Engraving Co., Menasha, Wisconsin. The page trim size is $6 \times 9$ inches. The type page is $26 x$ 43 picas. The type face is Linotype Baskerville, and Baskerville Bold set I I point on I 3 point. The text paper is jo-lb. White Deep Falls Enamel.

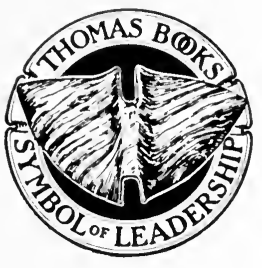

With THOMAS BOOKS careful attention is given to all details of manufacturing and design. It is the Publisher's desire to present books that are satisfactory as to their physical qualities and artistic possibilities and appropriate for their particular use. THOMAS BOOKS will be true to those laws of quality that assure a good name and good will. 
, 
$$
\text { . }
$$ 


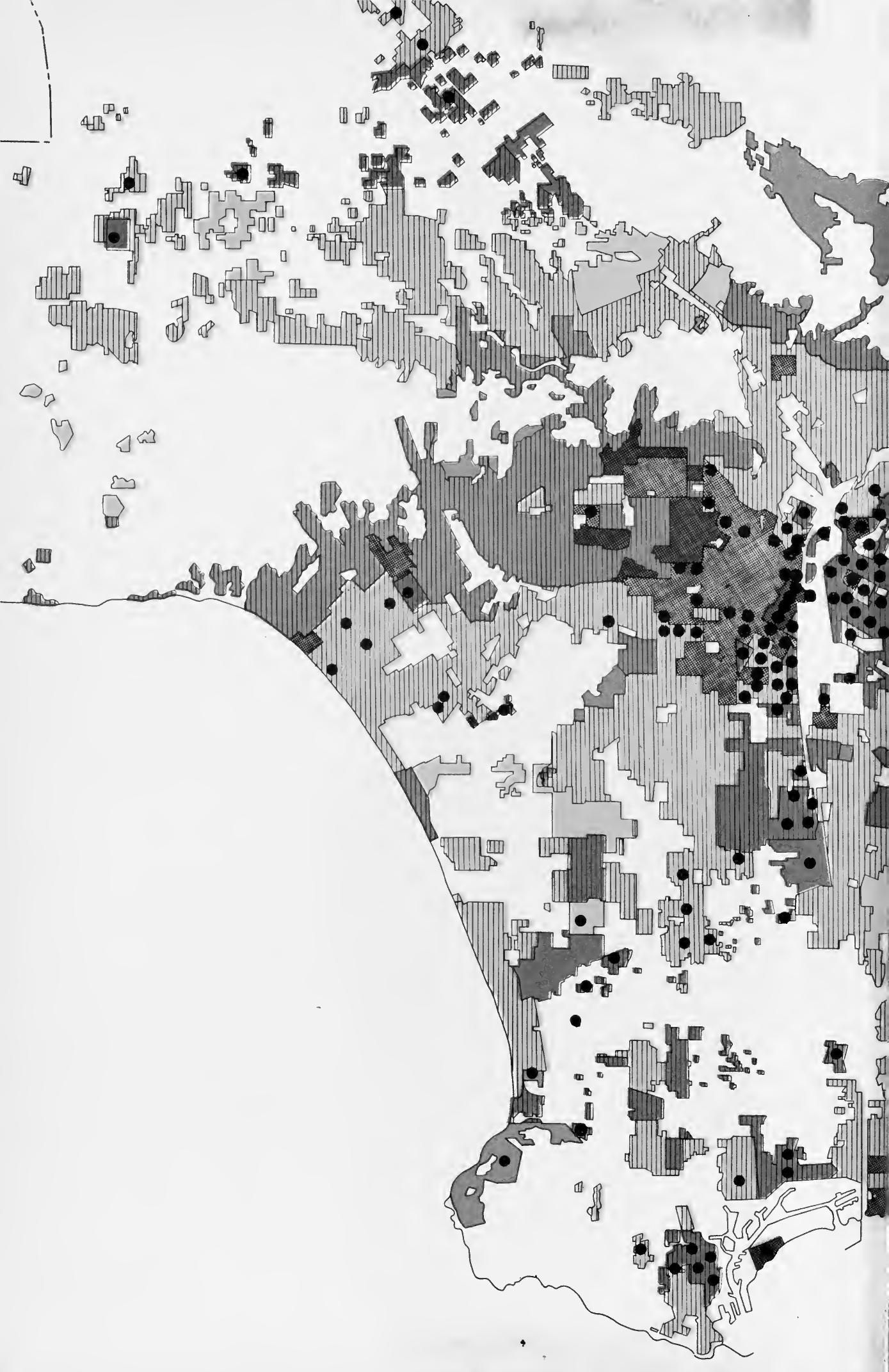




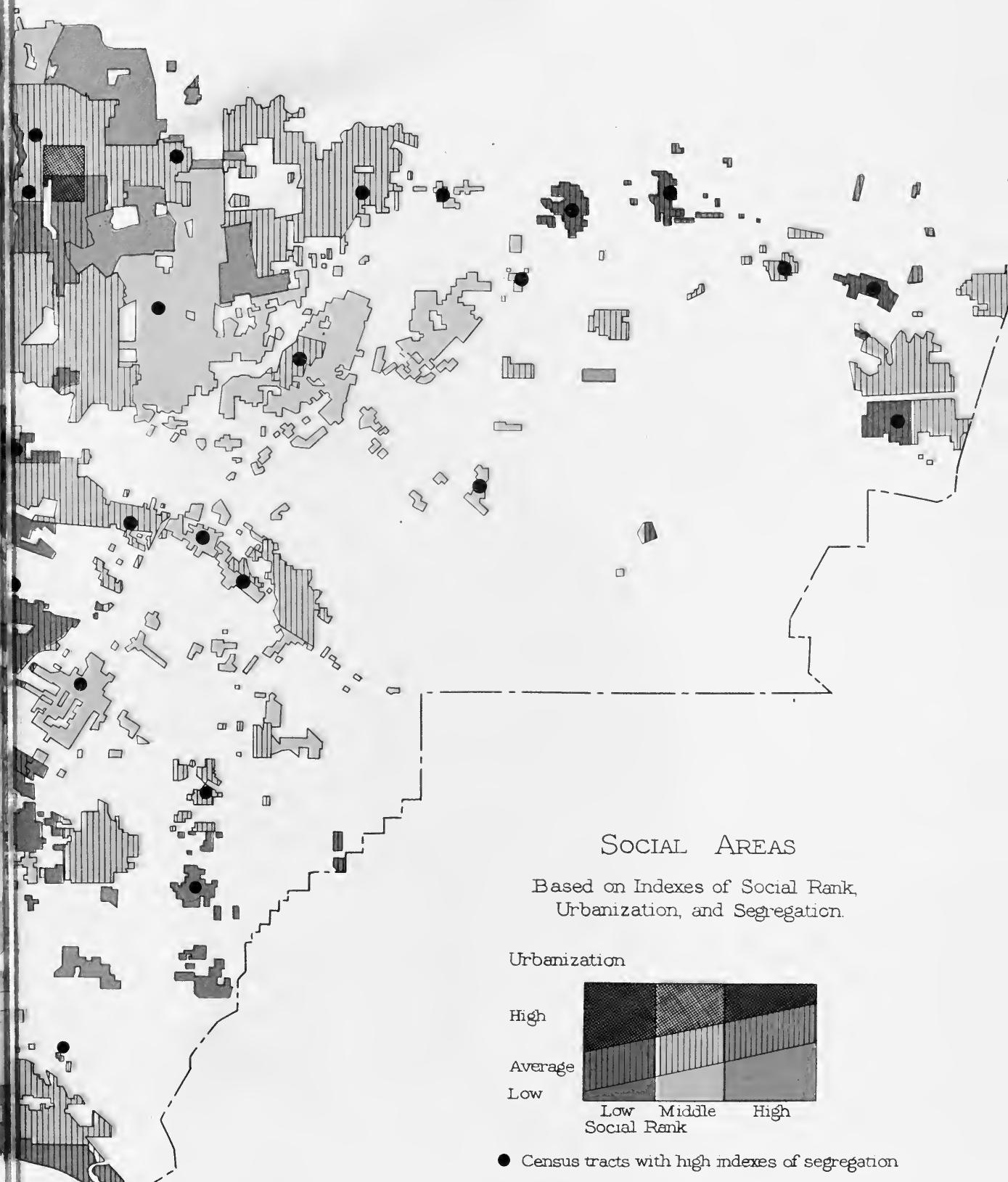


$40+4$ $+8$

W $4+2$

Non,

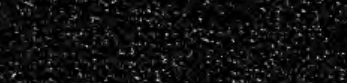
(2)

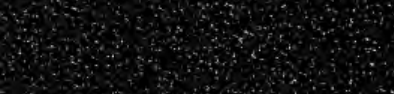

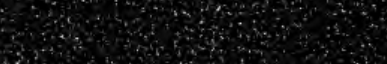

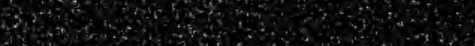

W. $36 \%$

$x^{2}+3 x+3$

(4) $4+2+10$ $30+3+2$

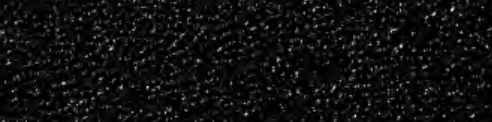

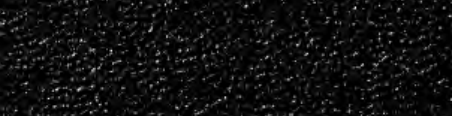

2

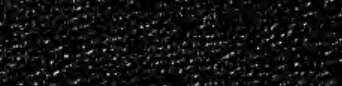

a 40

$4=0$

$4,0-0,0$.

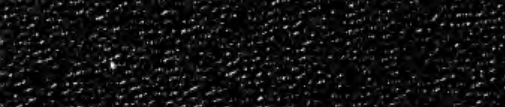
(4)

$+4$
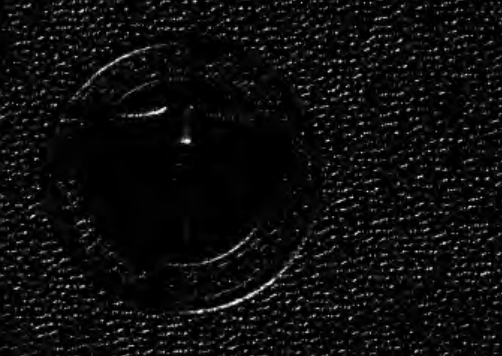